January 2006

\title{
Tort Suits Filed by Rape and Sexual Assault Victims in Civil Courts: Lessons for Courts, Classrooms and Constituencies
}

Ellen M. Bublick

\section{Recommended Citation}

Ellen M. Bublick, Tort Suits Filed by Rape and Sexual Assault Victims in Civil Courts: Lessons for Courts, Classrooms and Constituencies, 59 SMU L. REV. 55 (2006)

https://scholar.smu.edu/smulr/vol59/iss1/3 


\title{
Tort Suits Filed By Rape ANd Sexual Assault Victims in Civil COURTS: LESSONS FOR COURTS, Classrooms and Constituencies
}

\author{
Ellen M. Bublick*
}

W

HEN Los Angeles Lakers star guard Kobe Bryant and a nineteen-year-old Colorado woman who had accused him of rape, abandoned the criminal process last fall, no one argued that the process had worked well. Prosecutors' charge that Mr. Bryant had raped the woman was never adjudicated. Instead, a series of inept blunders by the criminal court led to repeated public release of sealed documents, the woman's complete loss of privacy, and her abandonment of the case. ${ }^{1}$ When the parties stepped out of this failed process, they did not relinquish their prior controversy, but instead transported it to a new forum-civil adjudication. After reaching a settlement, the parties reported that the case was "resolved to the satisfaction of both parties."2 If true, this would have been no small achievement. For the parties to use this forum to resolve their dispute on mutually agreeable terms and move forward - a result that both must have desperately wanted after all of the pain that the criminal process inflicted on them ${ }^{3}$-then perhaps the civil forum served its function. And yet, the public has scant basis on which to

* Associate Professor of Law, University of Arizona James E. Rogers College of Law. A.B. Duke University, J.D. Harvard Law School. Many thanks to the organizers of the National Sexual Assault Law Institute and the Beyond Prosecution Conference at Suffolk University Law School. Particular thanks to Susan Vickers of the National Victims' Rights Law Center, who encouraged me to return to this topic of civil actions in cases of sexual assault. Thanks also to my research assistant Aeryn Heidemann for her prompt, exacting, and insightful work, and to Barbara Atwood, Jack Chin, Suzanne Diaz, Jo Evelyn Ivey, David Jacobs, Mary Koss, Marc Miller, Richard Posner, Susan Schwen, Ken Simons, and the editors of the SMU Law Review for their thoughtful suggestions on an earlier draft.

1. Kirk Johnson, The Bryant Trial: Anatomy of a Case that Fell Apart, N.Y. TIMEs, Sept. 3, 2004, at A14.

2. Kirk Johnson, Settlement Is Reached in Bryant Case, N.Y. TimEs, Mar. 3, 2005, at A14 [hereinafter Johnson, Settlement].

3. See, e.g., Wire Reports, Sun-Sentinel, Jun. 28, 2005 (reporting the criminal conviction of a man who made seventy profanity-laced death threats to the accuser and prosecutor in the Kobe Bryant case); Ed Caesar, Not a Very Good Endorsement, INDEPENDENT, Mar. 31, 2005 (noting that Kobe Bryant lost renewal of contracts with McDonald's and Ferrero and about \$4-6 million in endorsements as a result of the scandal). 
judge the fairness of this result. ${ }^{4}$ Little is known about either the terms of the settlement or the underlying merits of the case-resolution having been reached not only before trial but also before either party was deposed. ${ }^{5}$

But while little can be said of the fairness of the civil process in the Kobe Bryant case itself, more can and should be known about the use of civil suits in rape and sexual assault cases more broadly-whether used as a direct substitute for the criminal process, as in the Kobe Bryant case, or against parties unlikely to be subject to criminal charges at all, as in recent cases filed against archdioceses for their failure to adequately respond to child sexual assault by priests. ${ }^{6}$

This article begins to bridge the gap between the current wide-ranging use of tort suits in sexual assault cases and the limited public knowledge about these suits. In particular the article has three goals. First, it brings to light the varied and increasing number of civil suits pursued by sexual assault victims. ${ }^{7}$ Specifically, the article examines tort actions that were filed by victims of sexual assault and resolved by state appellate courts, particularly state supreme courts, in the five years from January 1, 2000 to December 31, 2004. The article addresses the dramatic increase in appellate-level litigation over the last thirty years even absent formal legal changes in the definitions of many of the underlying torts themselves. This increase in litigation, along with changes in the nature of the lawsuits filed, reflects specific doctrinal developments, as well as broader changes of social norms.

Second, in light of the tort actions filed by victims of sexual assault and resolved by appellate courts in the 2000 to 2004 time period (a large number of actions in spite of the limited time frame), this article addresses a question raised years ago and presented with increased public interest

4. Jon Sarche, Civil Lawsuit Against Bryant Settled; Terms are Kept Secret, CourIERJ., Mar. 3, 2005, at 1C (noting the parties statements that no further comments on the matter will be made and speculating that the settlement agreement likely contains penalties for revealing any details).

5. Johnson, Settlement, supra note 2, at A14.

6. See, e.g., Malicki v. Doe, 814 So. 2 d 347 (Fla. 2002) (analyzing a suit by parishioners against archdiocese for claims related to sexual assaults by priest); Pam Belluck, Diocese Is the First to Settle a Criminal Case Over Abuse, N.Y. TIMEs, Dec. 11, 2002, at A31 (reporting that the Roman Catholic Diocese of Manchester, New Hampshire, was the first diocese to settle a criminal suit, ending plans to file charges against it, and that no other diocese in the country has ever faced criminal charges); 70 More Bring Sexual Abuse Lawsuits in Boston Archdiocese, N.Y. Times, Jan. 30, 2003, at A14 (stating that some 470 outstanding lawsuits had been filed against the archdiocese or its priests stemming from sexual assault claims).

7. In some of the cases reviewed in this article, assailants were convicted, had default judgments entered against them, or were found liable by a jury in a civil and/or criminal case. Many of the cases reviewed in this article involve litigation that has not yet proceeded to a final resolution of claims. For simplicity, the article often refers to the plaintiffs in these cases as "sexual assault victims" or "victims," although many of these plaintiffs can be referred to as "alleged victims." Similarly, at times the article generically refers to defendants in these cases as "assailants" or "rapists," regardless of whether a jury has determined that the particular defendant has committed assault or whether the case is still at a more preliminary stage. 
since the Kobe Bryant case-to what extent can and should victims use tort actions as a direct alternative to the criminal process ${ }^{8}$ As judged by the appellate case law, tort actions can be and have been pursued as an alternative to criminal fora, though such use of the tort system is still atypical. Whether victims would be well advised to pursue tort actions as a more commonplace alternative to the criminal process presents something of a mixed picture. Tort actions present a number of advantages for victims proceeding against alleged assailants. These advantages include a more even distribution of procedural benefits enjoyed by the parties and a more fluid definition of the prohibited harmful conduct. And yet, tort fora may serve an individual victim's interests without addressing broader public objectives. In addition, tort doctrine, though different from criminal law in a number of ways that can benefit victims, still presents a significant set of concerns and challenges for victims. These challenges arise through doctrines such as consent that have criminal law analogs and through other doctrines such as comparative apportionment that do not have direct criminal corollaries.

Finally, although the Kobe Bryant case itself concerned the use of tort law by an alleged victim directly against an alleged rapist, the hundreds of recent appellate opinions in tort suits filed by sexual assault victims more frequently examine the legal liability of employers, businesses, schools, nursing homes, foster parents, and other entities sometimes referred to as "third parties." In light of the prevalence of third-party claims in the appellate litigation, this article examines a third question-in cases involving third parties, which substantive legal issues are the most recurrent and important, warranting the attention of courts, legislatures, and the public as a broader constituency? Ultimately, I identify four key issues that call for further focused examination: 1) the extent and nature of corporate and individual responsibility to use reasonable care to prevent sexual assault; 2) the appropriate measure of damages to victims of sexual assault and the division of responsibility for damages among assailants, victims, and third parties; 3 ) the availability of compensation mechanisms such as insurance to redress the losses suffered by victims of sexual assault; and 4) the protection of victim privacy within and through the civil process. Although it is not possible to closely analyze each of these broad issues in a single article, this article begins to lay the empirical groundwork for further analysis.

In keeping with these threefold objectives, this article is organized into three discrete sections. Section I provides information about recent appellate court rulings in tort suits that stem from rape and sexual assault. The section notes changes in the case law over the last thirty to forty years, and takes a particular look at cases in which tort actions are being used as an alternative to criminal trials and convictions. It also identifies some broad characteristics of current third-party litigation. Section II looks at the potential procedural and substantive advantages to victims of

8. Robin Warshaw, I Never Called It Rape 144 (1988). 
filing tort as opposed to criminal claims. This section notes also potential obstacles that victims may encounter in the tort law. Finally, Section III identifies important unresolved issues presented in the third-party case law that warrant further thought and coordinated analysis by decisionmakers.

My goal in this article is to attend to the realities of current litigation by sexual assault victims so that the many important issues that arise in these tort cases will not only be litigated in the courts (as they clearly are), but also discussed across jurisdictions and beyond the courthouse, and viewed together for the wider forest that they have become.

\section{CURRENT TORT CASES INVOLVING SEXUAL ASSAULT}

Unlike distant inquiries such as exploration of the landscape on Mars, examination of legal actions, filed and reported as they are in public fora, would seem to hold no surprises. ${ }^{9}$ Yet so little research has been done on the nature and outcomes of civil actions that stem from sexual assaul, that the results are surprising.

As judged by state appellate court decisions, the number of civil cases being litigated by sexual assault victims has increased dramatically, perhaps exponentially, in the last thirty years. To attach some numbers to these observations, in the five years from January 1, 2000 to December 31,2004 , state supreme courts by themselves issued rulings in more than one hundred tort cases filed by rape and sexual assault victims. ${ }^{10}$ In that same time period, intermediate appellate court decisions in these cases also numbered in the hundreds. ${ }^{11}$ This is not counting the many federal appellate court opinions issued in such cases. ${ }^{12}$ By contrast, just thirty

9. John Schwartz, Rover Unearths More Evidence of Water on Mars, Scientists Say, N.Y. Times, Jun. 9, 2004, at A19 (noting excitement that research hinted at the past possibility of water and life on that planet).

10. These cases are listed in Appendix A. Several commentators discuss "civil" cases filed by sexual assault victims, in contrast to "criminal" cases. See, e.g., Quince Hopkins, Mary Koss, \& Karon J. Bachar, Applying Restorative Justice to Ongoing Intimate Violence: Problems and Possibilities, 23 St. Lours U. PuB. L. Rev. 289, 294 (2004) (mentioning "civil justice" options for victims). Civil cases encompass a wide variety of disputes, including adjudication of child custody, parental visitation rights, disciplinary sanctions, and other issues. Rather than address all civil cases filed by sexual assault victims, this article focuses on a subset of those cases-tort actions filed by sexual assault victims and the insurance coverage disputes that arise from them. The border of claims that fall within this narrower category is somewhat fluid. Not included in this category are the additional tort suits brought by alleged assailants for claims like defamation or violation of due process rights. See, e.g., Doe v. Superintendent of Sch. of Stoughton, 767 N.E.2d 1054 (Mass. 2002); Schaer v. Brandeis Univ., 735 N.E.2d 373 (Mass. 2000). Similarly, cases brought by third parties, for example newspapers seeking access to court records, are generally excluded as well. WLJA-TV v. Levin, 564 S.E.2d 383 (Va. 2002); Doe v. Gonzaga, 24 P.3d 390 (Wash. 2001) (en banc).

11. For a partial listing, see Appendix B.

12. See, e.g., Doe v. Celebrity Cruises, Inc., 394 F.3d 891 (11th Cir. Fla. 2004) (holding cruise ship liable for sexual assault of passenger perpetrated by cruise ship employee); Kurtz v. Unified Sch. Dist. No. 308, 65 Fed. Appx. 257, (10th Cir. 2003) (declining to hold school district liable for negligent hiring after student was raped by teacher because risk of the district employee sexually molesting the parent's minor son was not foreseeable as a 
years earlier, from January 1, 1970 to December 31, 1974, state supreme courts heard fewer than ten of these controversies ${ }^{13}$ and intermediate state appellate courts resolved fewer than ten more. ${ }^{14}$

In terms of sheer number of appeals, tort cases stemming from sexual assault are in the ascendency. ${ }^{15}$ Given the expectation that more than $95 \%$ of all cases settle before trial, ${ }^{16}$ and that most lower court judgments are not appealed, ${ }^{17}$ the great number of cases that are likely being filed at the trial-court level becomes apparent.

This trend toward increased appellate-level tort litigation by sexual assault victims in the United States is robust across regions. In the 2000 to 2004 case law, appellate courts in at least forty-seven of fifty states, as well as the District of Columbia, issued opinions in tort cases filed by sexual assault victims. ${ }^{18}$ The data from Colorado, the state in which the Kobe Bryant suit was filed, mirror national trends. Although a 1919 Colorado case recognized the existing right of a rape victim to file civil suit against an assailant, ${ }^{19}$ a significant number of appeals did not begin to appear at the appellate level in that state until the 1980s and 1990s. ${ }^{20}$

matter of law); Beul v. Asse Int'l, 233 F.3d 441 (7th Cir. 2000) (holding international student exchange program liable for negligence in performance of contract by failing to prevent foreign exchange student's rape by her sponsor).

13. See generally Cox Broad. Corp. v. Cohn, 200 S.E.2d 127 (Ga. 1973); Seymour v. Lofgreen, 495 P.2d 969 (Kan. 1972); Brewer v. Roosevelt Motor Lodge, 295 A.2d 647 (Me. 1972); Int'l Paper Co. v. Cont'l Cas. Co, 35 N.Y.S.2d 322 (N.Y. 1974); Bass v. New York, 32 N.Y.2d 894 (N.Y. 1973); Felsenthal v. McMillan, 493 S.W.2d 729 (Tex. 1973); Schurk v. Christensen, 497 P.2d 937 (Wash. 1972).

14. See generally Brown v. Rosenbloom, 524 P.2d 626 (Colo. Ct. App. 1974); Collier v. AMI, Inc., 254 So. 2d 170 (La. Ct. App. 1971); Int'l Paper Co. v. Cont'l Cas. Co., 348 N.Y.S.2d 6 (N.Y. App. Div. 1973); Bass v. City of New York, 330 N.Y.S.2d 569 (N.Y. App. Div. 1972); Smith v. ABC Realty Co., 322 N.Y.S.2d 207 (N.Y. App. Div. 1971); Romisher v. SEPTA, 65 Pa. D. \& C.2d 483 (Pa. Cty. 1974); Commercial Std. Ins. Co. v. Marin, 488 S.W.2d 861 (Tex. Civ. App.-San Antonio 1972).

15. The 1970s cases may underestimate cases of sexual assault because that term was not as widely used at that time. However, a sampling of battery and assault cases from the time suggests there were not a large number of sexual assault cases referred to by a different title but rather genuinely fewer sexual assault cases litigated in the appellate courts.

16. See Haworth Inc. v. Steelcase, Inc., No. 4:85 CV 526, 1992 WL 457284, at *5 (W.D. Mich. 1992); Marc Galanter, The Hundred Year Decline of Trials and the Thirty Years War, 57 Stan. L. REv. 1255, 1258-59 n.15 (2005) (discussing research showing that the number of trials is small and declining and that only $1.7 \%$ of disputes were resolved through trial in 2003); Valerie P. Hans \& Stephanie Albertson, Empirical Research and Civil Jury Reform, 78 Notre Dame L. Rev. 1497, 1503 (2003) (finding that 3\% of cases proceed to trial).

17. See Bradley C. Canon \& Charles A. Johnson, Judicial Policies: ImplemenTATION AND IMPACT 33 (2d ed. 1999) (suggesting that in federal courts only one-fifth of trial court decisions are appealed).

18. See Appendix A \& Appendix B.

19. Weinlich v. Coffee, 176 P. 210, 210-11 (Colo. 1919) (noting that a married woman "may maintain an action to recover damages for injury sustained by reason of forcible rape," but holding that the plaintiff, a married woman living apart from her husband, had no cause of action for seduction).

20. See, e.g., In re Questions Submitted by United States Court of Appeals for the Tenth Circuit, 759 P.2d 17, 26 (Colo. 1988) (holding that employee, who was raped by janitor while walking on her employer's campus, could not pursue her negligence claims against employer because her sole remedy for relief was under the Workmen's Compensation Act); Allstate Ins. v. Troelstrup, 768 P.2d 731, 731 (Colo. Ct. App. 1988) (en banc) 
Tort suits filed by victims of sexual assault are now litigated throughout the country.

This increased litigation may reflect any number of changed social norms. The change that can be seen most clearly by comparing the early 1970 s and early twenty-first century case law is the broadening understanding of social responsibility for sexual assault prevention. Older cases did not expect anyone but the assailant or the victim to prevent the assault. Accordingly, cases filed by sexual assault victims and decided by appellate courts in the 1960s were suits that were either directed at the assailant himself, ${ }^{21}$ or were unsuccessful. ${ }^{22}$ Although plaintiffs began arguing for the expansion of responsibility (particularly public agents' and entities' responsibility) in the 1960s, and early 1970s, courts were hesitant to require parties other than the assailant or the victim to take preventative measures. ${ }^{23}$

(remanding matter to trial court for jury determination of whether sexual assault was intentional and therefore outside the scope of insurance coverage).

21. See Monsma v. Williams, 385 P.2d 107, 108, 111 (Alaska 1963) (upholding trial court finding that man who allegedly sodomized plaintiff was not guilty of assault and battery, in light of plaintiff's acquiescence in drinking and amorous affection that preceded the act); Taylor v. Sullivan, 118 N.W.2d 421 (Mich. 1962) (reviewing case in which jury ruled against plaintiff who sued physician for assault, battery and malpractice stemming from alleged rape); Goode v. Martinis, 361 P.2d 941, 945 (Wash. 1961) (en banc) (permitting divorced wife to sue husband for rape that husband allegedly committed before the divorce); Kink v. Combs, 135 N.W.2d 789, 798-99 (Wis. 1965) (upholding $\$ 12,500$ award in assault and battery case brought by restaurant manager who was sexually assaulted at work against assailant who was owner of a different restaurant).

22. See City of Green Cove Springs v. Donaldson, 348 F.2d 197, 203 (5th Cir. 1965) (holding that plaintiff raped by officer could not show that conduct was attributable to city); State v. Markway, 353 S.W.2d 727, 734 (Mo. 1962) (holding that minor female prisoner who had sexual intercourse with jailer had no suit against jailer, bonding company or sheriff based on evidence that she consented to intercourse); Goldberg v. Hous. Auth. of the City of Newark, 186 A.2d 291, 270-99 (N.J. 1962) (holding that municipal housing authority had no duty to provide police protection at housing project); Gallagher v. City of New York, 30 A.D.2d 688, 688 (N.Y. App. Div. 1968) (reversing judgment against city and city board of education secured by girl who was raped in school by classmates while on an errand for teacher on the ground that evidence of prior incidents of violence at the school were prejudicial, and that jury's $\$ 66,000$ award was excessive). But see Danile v. Oak Park Arms Hotel, Inc., 203 N.E.2d 706 (Ill. App. Ct. 1964) (upholding liability of hotel to guest who had been raped by bellman who had been drinking and had taken plaintiff's room pass key from a place whether other employees would have seen him, in part because of high degree of care owed by innkeeper). A case that allowed recovery for the plaintiff, but reflects the sexual and racial restrictions of the time more than a broad understanding of responsibility for assault prevention is Kennedy v. Cannon, 182 A.2d 54 (Md. 1962). The court allowed the plaintiff to maintain a defamation claim against an attorney who told a newspaper that the black defendant accused of rape said that plaintiff, a white female, had "submitted to his advances willingly." Id. at 56.

23. See generally Brewer v, Roosevelt Motor Lodge, 295 A.2d 647 (Me. 1972) (declining to find motel liable for sexual assault to motel guest when assailant entered through motel window); Bass v. City of New York, 32 N.Y.2d 894 (N.Y. 1973) (dismissing claims brought by father of deceased victim against the City of New York for failing to provide adequate police protection after nine-year-old daughter was abducted from housing project where she lived, raped, and then dropped fourteen stories to her death). But see Schurk v. Christensen, 497 P.2d 937 (Wash. 1972) (affirming defendant-parents' liability for sexual assault of plaintiff's daughter after defendants recommended their son for babysitting and son had a history of sexually deviant behavior). 
The 2000 to 2004 case law is markedly different. Many of the cases from this later time period are concerned with institutional responsibility to affect the conditions that make sexual assault prevalent and largely unsanctioned. ${ }^{24}$ At the appellate level, the vast majority of tort claims filed by sexual assault victims involve at least some claims against a thirdparty defendant. ${ }^{25}$ Although assailants themselves may still be named as defendants in the current cases, their responsibility is a far less frequent focus of the inquiry. ${ }^{26}$ Instead, current appellate-level tort litigation is more frequently focused on the liability of third-party actors who would not generally be subject to criminal penalties. Consequently, the change in tort cases filed by sexual assault victims is not just an increase in the amount of litigation, but an evolution in the very nature of the litigation itself.

Doctrinally, the reasons for the shift toward a wider discussion of responsibility for sexual assault prevention are easy to see. Courts have increasingly recognized third-party duties to use reasonable precaution not only to prevent negligent harms, but also to prevent intentional torts. ${ }^{27}$ For example, today nursing homes have an obligation to use reasonable care to protect their patients from foreseeable sexual assaults, as well as foreseeable slip-and-falls. ${ }^{28}$ When a cable company ignores reports that its employee is threatening customers, it does so at the risk of potential liability if that abusive employee subsequently attacks another customer in her home. ${ }^{29}$ Some of this expansion is simply a logical outgrowth of the more general foreseeability principle. Sexual assaults, like slip-and-falls, do occur at nursing homes, making both of these events foreseeable and the worthy focus of precaution.

The social influences fueling this expanded sense of the foreseeability of sexual assault are potentially wide-ranging. Doctrinal expansion of the tort law requiring private precautions against sexual assault and other crimes occurred after a time period in which crime in the United States began to increase dramatically, ${ }^{30}$ making crime both more foreseeable and more imperative to combat. Expansion of national broadcasting me-

24. See S. Rep. No. 101-545, at 33 n.30 (quoting H. Field \& L. Bienen, Jurors ANd Rape: A Study in Psychology AND LaW 95 (1980) (stating that an individual who commits rape has only about four chances in one hundred of being arrested, prosecuted, and found guilty of any offense)).

25. See infra notes $64-70$ and accompanying text.

26. See infra note 50 (noting suits in which the victim settled with the assailant at an earlier stage in the lawsuit).

27. See id.; see also Robert L. Rabin, Enabling Torts, 49 DePaul L. Rev. 435, 445-50 (1999); Gary T. Schwartz, The Beginning and the Possible End of the Rise of Modern American Tort Law, 26 GA. L. Rev. 601, $649-50$ (1992). This broader sense of duty can been seen in duty, negligence and proximate cause cases.

28. See, e.g., Regions Bank \& Trust v. Stone County Skilled Nursing Facility, 49 S.W.3d 107, 112 (Ark. 2001).

29. Saine v. Comcast Cablevision of Ark., Inc., 126 S.W.3d 339, 497 (Ark. 2003).

30. See Gary Lafree, Explaining the Crime Bust of the 1990s, 91 J. CRIM. L. \& CrimiNOLOGY 269, 270 (2000) (using uniform crime statistics to show that crime rapidly increased in the 1960 s and early 1970 s, resulting in more than a $50 \%$ increase in homicides). 
dia including television may have made these stories more widelyaccessible.

The foreseeability of sexual assault in particular may have been fueled by changes in gender roles and in sex-related norms. In terms of gender roles, increased assertion of tort claims may reflect women's greater economic and political power. In addition, the movement for rape law reform in the criminal arena may have influenced the public's awareness of and feelings about the problem of sexual assault more broadly. ${ }^{31}$ Increased social acceptance of consensual sexual activity and greater discussion of sexual topics more generally may play a role in the increased litigation too. Sexual assault victims may be more willing to acknowledge victimization publicly in light of decreased public sanctions against them, such as marriage penalties against women who are not virgins ${ }^{32}$ and increased social supports for victims, including the existence of rape crisis centers and notable national role models. ${ }^{33}$

The contemporary case law's intrinsic sense that private parties should play a role in curtailing sexual assault may stem from additional factors. In the sexual assault context, the passage of laws banning sexual harassment and discrimination may have made sexual assault less acceptable and institutions' role in preventing it more accepted. ${ }^{34}$ More broadly, factors like the growth of retail operations to megastores and the expansion of malls on private property rather than public downtowns may have affected both the perceived propriety of and need for private policing. Many other normative changes may be important as well. ${ }^{35}$

31. Cass R. Sunstein, Social Norms and Social Roles, 96 Colum. L. REv. 903, 907 (1996) (arguing that norm entrepreneurs can take advantage of the fact that people have weak commitments to most norms) [hereinafter Sunstein, Social Norms].

32. See Nicholas D. Kristof, Sudan's Department of Gang Rape, N.Y. Times, Nov. 22, 2005, at A23 (exceptional stigma of rape in Sudan silences victims even as it terrorizes the entire population); Emily Wax, Ethiopian Rape Victim Pits Law Against Culture, WAsH. Post, Jun. 7, 2004, at A01 (noting impossibility of bringing a rape case in the rural areas of Africa where victim's virginity is questioned, unmarried victims are encouraged to marry their assailants, and married women are abandoned by their husbands if raped).

For an example of traditional discomfort with public discussion of sexual topics, see AlA. CODE $\S 12-21-9$ (2005) (code enacted in 1907 giving the trial judge the right to clear people out of the courtroom in civil cases involving the question of rape or issues involving evidence that is vulgar, obscene, or tending to debase the morals of the young).

33. See In re Pittsburgh Action Against Rape, $494 \mathrm{~Pa} .15,58$ (Pa. 1981) (noting increased numbers of rape crisis centers); WILLIAM H. WEBSTER. DIRECTOR, FBI, UNIFORM Crime Reports: Crime in the United States 1979 (recounting increase in number of crisis centers in 1970s, as well as one hundred percent increase in number of rapes); David Heinzmann, Groups Seek New System to Help Treat Rape Victims; Experts Would Target Emotional, Legal Needs, ChiCago Trib., Mar. 5, 2000, at 1D; Cynthia Bowers, Oprah Takes on Child Molesters (CBS News Broadcast, Oct. 12, 2005) (recounting Oprah's disclosure that she was raped at nine years old and molested for five years afterwards).

34. Sunstein, Social Norms, surpa note 31, at 907 (arguing that behavior is basically a function of norms and that law can be used to change norms).

35. For example, in tort suits involving sexual assaults by spouses, the increased social acceptance of divorce may be a factor in willingness to sue. See C. Quince Hopkins, Mary P. Koss, \& Karen J. Bachar, Applying Restorative Justice to Ongoing Intimate Violence: Problems and Possibilities, 23 St. LouIs U. Pub. L. Rev. 289, 289 (2004) (noting high rates of assaults against women that stem from family violence, particularly by partners). Similarly, cultural attitudes about the appropriateness of lawsuits may be a factor. 
A number of these varied social changes can be seen in the case law itself. For example, even forty years ago courts were unwilling to address whether a victim who consented to foreplay had nevertheless refused consent to intercourse. ${ }^{36}$ Similarly, older case law did not feel compelled to provide any explanation for why a $\$ 66,000$ award to a thirteen-year-old child who had been raped at school was excessive, while newer cases are more protective of children ${ }^{37}$ and, even when not, at least give lip service to the perception that rape causes serious harm. ${ }^{38}$

Although one might expect changed social norms regarding culpability of assault and appropriateness of private precautions to expand criminal liability as well as tort liability, some studies suggest that the criminal law has not changed significantly. ${ }^{39}$ Perhaps this is because criminal sanctions are viewed as too harsh a penalty for this expanded liability. ${ }^{40}$ It would be interesting to learn that advocacy directed at criminal law reform has worked not by changing the criminal law at all (though formal statutes have been rewritten), but instead by changing social norms and in turn the law of torts, with a resultant change in structural incentives.

Whatever the reasons for the expansion in tort litigation filed by sexual assault victims, today cases filed by victims include two types of viable claims-claims against assailants themselves and claims against third parties. Often, these two types of action are filed in a single lawsuit.

With respect to claims against assailants, one empirical question is whether these claims are pursued as a substitute for the criminal process. In the 2000 to 2004 state supreme court cases, tort actions filed by sexual assault victims against alleged rapists - cases in which the civil law might be thought to provide victims with a direct alternative to the criminal courts-do exist but are relatively few in number. Nevertheless, examples of cases that appear to fit the criminal-law-substitute profile can be found at both the state supreme court and state lower appellate court level.

At times, victims have succeeded on tort claims when prosecutors were unable to obtain criminal convictions. ${ }^{41}$ For example, in one recent South

36. See Monsma v. Williams, 385 P.2d 107, 110 (Alaska 1963) (noting plaintiff's argument that with respect to the attempted rape "the court was wrong in deciding as a matter of law that the plaintiff's actions created a consent to sexual intercourse and in then theorizing that such consent could not be withdrawn" but upholding trial court's finding that a man who allegedly sodomized plaintiff was not guilty of assault and battery, in part based on plaintiff's acquiescence to drinking and amorous affection that preceded the act).

37. Compare Gallagher v. City of New York, 30 A.D.2d 688 (N.Y. App. Div. 1968), with Doe Parents No. 1 v. Dep't of Educ., 58 P.3d 545 (Haw. 2003) (providing much larger compensatory damage award for teacher's assaults on students that fell far short of rape).

38. See Kravitz v. Beech Hosp., 808 A.2d 34, 41 (N.H. 2002). (2000).

39. See generally David P. Bryden, Redefining Rape, 3 Buff. Crim . L. Rev, 317

40. See generally Dan M. Kahan, Solving the Sticky Norms Problem: Gentle Nudges v. Hard Shoves, 67 U. CHI. L. REv. 607 (2000) (suggesting that law is more effective in changing social norms when it takes smaller steps against existing social norms).

41. See also Jeffreys v. Griffin, 801 N.E.2d 404 (N.Y. 2003) (pursuing tort action after physician's conviction was reversed on appeal and a retrial resulted in an acquittal). 
Dakota Supreme Court case, St. Paul Fire \& Marine Insurance Co. v. Engelmann, ${ }^{42}$ a woman alleged that she had been raped by her doctor while he was ostensibly performing a pelvic exam. She contacted police, and when her allegations became public, three other women came forward with similar claims. The prosecutor charged the doctor with multiple counts of rape, but a jury acquitted him of all charges. ${ }^{43}$ In the subsequent tort action, the jury awarded each victim $\$ 450,000$ in damages. ${ }^{44}$ On appeal, the South Dakota Supreme Court held that the doctor's improper sexual contact constituted actionable "malpractice." 45 Consequently, the plaintiffs in Engelmann recovered on their tort claims despite the fact that the prosecutor had not prevailed in a criminal trial. ${ }^{46}$

Victims have not only brought tort claims when criminal prosecution was unsuccessful, but also when criminal prosecution was not pursued. A tort case that apparently served this criminal-law-replacement function is Weldon $v$. Rivera. ${ }^{47}$ In Weldon, the plaintiff complained that defendant Gilbert Rivera had sexual intercourse with her in her dormitory room after "she verbally objected to the act of intercourse," and "was so intoxicated that she passed in and out of a state of consciousness." 48 She further complained that co-defendant Edwin Touma, acted in concert with Rivera by encouraging her to consume additional alcohol after she was intoxicated and watching and kissing her during the act of intercourse with Rivera. ${ }^{49}$ The plaintiff sought damages for injuries caused by the defendants' conduct. 50

No prior or pending criminal proceedings resulting from the defendants' conduct were cited in the court's opinion. ${ }^{51}$ Proceeding in this civil arena, defendant Rivera did not challenge whether he might be held liable based on the facts alleged in the plaintiff's complaint. Moreover, both the trial court and the appellate court held that plaintiff had stated a legal claim under which defendant Touma might also be held liable. ${ }^{52}$ The plaintiff could proceed with her case on the theory of concerted actionthat "those who, in pursuance of a common plan or design to commit a tortious act, actively take part in it ... or who lend aid and encouragement to the wrongdoer . . . are equally liable with him." 53

42. 639 N.W.2d 192 (S.D. 2002).

43. Id. at 195 .

44. Id. (awarding $\$ 50,000$ damages each to the husbands of two plaintiffs).

45. Id. at 195-96.

46. Id. at 192 .

47. 301 A.D.2d 934 (N.Y. App. Div. 2003).

48. Id. at 934.

49. Id. at 935 .

50. Id. at 934 .

51. An independent search reveals a 1996 assault case against a defendant Gilbert Rivera, People v. Rivera, 233 A.D.2d 344 (N.Y. App. Div. 1996). It is not possible, however, to tell from the published opinions whether that case involves the same defendant and/or plaintiff. Since 1990, no "Gilbert Rivera" has been committed to the New York State Department of Corrections for a sex offense. See www.nycourts.gov/apps/chrs/.

52. Weldon, 301 A.D.2d 934, 934-35.

53. Id. at 935 (citing an earlier case that in turn had quoted William L. Prosser, TORTs $\S 46$, at 292 (4th ed. 1971)). The appellate court did dismiss plaintiff's claims of 
That the plaintiff was permitted to against proceed with her claims against not just the primary defendant but also an accomplice, in a case involving acquaintances, a college student, and heavy alcohol use, suggests that tort cases may be able to accommodate some of the cases that have proved so difficult in the criminal forum..$^{54}$

Cases like Engelmann and Weldon are not alone. In a number of recent appellate court cases plaintiffs pursued tort claims against an assailant as the sole defendant. ${ }^{55}$ Often these claims were filed against stepfathers and other loosely-related relatives. ${ }^{56}$ However, these cases, while suggestive of the potential for sexual assault victims to use tort actions as an alternative to the criminal law, are not emblematic of broad current usage. At least at the appellate level, only a small percentage of the tort cases filed by sexual assault victims seem to fill this direct criminal-lawsubstitute role. In many if not most tort cases, the assailant is sued alongside other third-party defendants. ${ }^{57}$ In a number of these actions, claims against the assailant were resolved before trial and before resolution was reached with third parties. ${ }^{58}$ In a few tort cases, the assailant was not sued at all. ${ }^{59}$ Moreover, even when tort actions were filed against assail-

recklessness and negligence on the ground that the state had no legal precedent for such claims in this context. Id.

54. For difficulties of the criminal courts in addressing these cases see Commonwealth v. Neumyer, 731 N.E.2d 1053, 1060 (Mass. 2000), in which the majority wrote "the fact that the victim spent a night in the defendant's bedroom less than one week after reporting that he had raped her must call into question the validity of the report of rape," despite the defendant's confession to police and plea to criminal charges of assault and battery. See also Charlene Allen, SJC Rape Case Ruling Hurts Women, The Boston Globe, Jul. 17, 2000 , at A11.

55. See, e.g., L.C.H. v. T.S., 28 P.3d 915 (Alaska 2001) (step-granddaughter prevailing in suit against step-grandfather based on childhood sexual abuse); Herzfeld v. Herzfeld, 781 So. 2d 1070 (Fla. 2001) (permitting son to sue adoptive father); Hearndon v. Graham, 767 So. 2d 1179 (Fla. 2000) (plaintiff suing stepfather); Koenigstein v. McKee, No. 2002CA-002212-MR, 2004 WL 41738 (Ky. Ct. App. Jan. 9, 2004) (parents suing daughter's uncle based on his sexual assault) (ordered not published, original on file with the author); Bean v. Directions Unlimited, Inc., 609 N.W.2d 567, 570 n.5 (Mich. 2000); Frazier v. Badger, 603 S.E.2d 587 (S.C. 2004) (teacher bringing action against assistant principal); Palacios v. Robbins, No. 04-02-00388-CV, 2003 WL 21502371, at *2 (Tex. App. 2003) (wife filed divorce action claiming sexual assault and fraud as well).

56. See supra note 55.

57. See, e.g., Blier v. Greene, 587 S.E.2d 190 (Ga. Ct. App. 2003) (suit by counseling patients against clinic and therapist); Velez v. City of Jersey City, 850 A.2d 1238 (N.J. 2004) (suit by city employee against city councilman and city); Am. Commerce Ins. Co. v. Porto, 811 A.2d 1185 (R.I. 2002) (suit against boy scout troop leader, supervisor and Boy Scouts of America).

58. See Kravitz v. Beech Hill Hosp., 808 A.2d 34, 30 (N.H. 2002) (noting that patient settled case with other patient who allegedly assaulted her and proceeded with suit against hospital); Doe v. Forrest, 853 A.2d 48, 51 (Vt. 2004) (noting that victim assaulted by deputy originally sued deputy as well as sheriff, but "plaintiff voluntarily dismissed him from the case because of his lack of assets"); Majorana v. Crown Central Petroleum Corp., 539 S.E.2d 426, 427 (Va. 2000) (noting that at first gas station attendant accused of sexual assault was represented by counsel, but then he stopped cooperating with counsel and failed to appear in proceedings, and a default judgment was entered against him, although the case proceeded against gas station owner).

59. See Doe v. Baum, 72 S.W.3d 476, 478 (Ark. 2002) (examing case in which girl who was sexually assaulted by eighth-grade boy on a school bus sued bus driver, school district and others, but not assailant); Ashmore v. Hilton, 834 So. 2d 1131, 1134 (La. Ct. App. 
ants directly, many of these tort suits were not filed instead of other processes, but in addition to them. In a number of tort cases, the rapists already had been jailed ${ }^{60}$ or otherwise disciplined outside of the civil context. ${ }^{61}$

However, an important caveat is in order. Appellate cases may not fully reflect the extent of litigation against assailants at the trial court level. ${ }^{62}$ In tort suits against the assailant, many defendants who would be entitled to representation in the criminal process but not in the civil process may enter into settlements early on or accept default judgments entered against them. ${ }^{63}$ As such, while the appellate records suggest that civil litigation is not routinely used as a direct alternative to criminal litigation-suing an alleged assailant in lieu of criminal prosecution-further study at the lower-court level is necessary before satisfactory conclusions can be drawn concerning the number of such actions at the trial-court level.

Turning to the appellate-level cases filed by sexual assault victims against third parties rather than assailants alone, the cases are as numerous as they are varied. Third-party litigation seeks to obtain damages for victims from the broader institutions within which sexual assaults occur. The cases concern the responsibilities of schools, bus services, placement agencies, boy scout leaders, foster parents, hospitals, and mental health institutions. These cases also typically involve negligence, which is unlikely to be sanctioned through the criminal-law process. A large number of these tort cases stem from date or acquaintance rape. ${ }^{64} \mathrm{~A}$ notable, if

2002) (discussing case brought by girl, who was raped by inmate while performing community service for city, and who sued city and supervisor but not inmate).

60. See Koenigstein, 2004 WL 41738 (showing a defendant who had been jailed); Louviere v. Louviere, 839 So. 2d 57, 61 n.2 (La. Ct. App. 2002) (sheriff who went on a crime spree and committed crimes including sexual assault was punished under criminal law); Korhonen v. Allstate Ins. Co., 827 A.2d 833 (Me. 2003) (noting that father had been jailed for sexual assault); L.A.C. v. Ward Parkway Shopping Ctr. Co., L.P., 75 S.W.3d 247, 251 (Mo. 2002) (noting finding in juvenile court that the defendant acquaintance had committed rape); Seddon v. Bonner, 755 A.2d 823, 823 (R.I. 2000) (defendant convicted of second-degree child molestation); Smith v. Holmes, No. 03-02-00438-CV, 2003 WL 1561321 (Tex. App. May 8, 2003, pet. denied) (stepfather had been jailed for sexual assault); Forrest, 853 A.2d at 51 (noting that deputy had pleaded nolo contendere to charges of lewd and lascivious behavior); T.M. v. Executive Risk Indem., Inc., 59 P.3d 721, 724 n.2 (Wyo. 2003) (noting conviction and jailing of foster parent on ten counts of second-degree sexual assault).

61. See, e.g., Jeffreys v. Griffin, 801 N.E.2d 404, 410 (N.Y. 2003) (discussing impact on tort claim of hearing in which doctor's medical license was revoked); N.X. v. Cabrini Med. Ctr., 765 N.E.2d 844, 846 (N.Y. 2002) (noting that surgical resident who assaulted patient while she was recovering from surgery was terminated from employment after investigation); Martinmaas v. Engelmann, 612 N.W.2d 600, 610-13 (S.D. 2000) (admitting evidence in tort action that physician's application for re-issuance of medical license has been denied).

62. Cf. Marc L. Miller \& Ronald F. Wright, Secret Police and the Mysterious Case of the Missing Tort Claims, 52 Buffalo L. Rev. 757 (2004) (investigating the disparity between published appellate decisions in which civil claimants rarely win judgments against police officers and newspaper reports of civil settlements by police departments).

63. See supra note

64. See, e.g., Stanton v. Univ. of Me. Sys., 773 A.2d 1045, 1047 (Me. 2001) (student attending pre-season soccer program at university raped by a "young man" who walked 
not previously recognized facet of the third-party case law, is that a large number of the cases also involve particularly vulnerable victims including children, the permanently or temporarily disabled, and the infirm. ${ }^{65}$

The viability of third-party tort litigation is evident not only by the large number of cases reaching appellate courts, but also by the wide variety of legal questions presented in the litigation. No longer are appellate court cases exclusively focused on the threshold inquiry of whether a defendant has a duty to use reasonable care to take precautions against crime. Rather, current case law reaches well beyond this first-level inquiry to issues of negligence, ${ }^{66}$ actual cause, ${ }^{67}$ proximate cause ${ }^{68} \mathrm{dam}$ ages, ${ }^{69}$ and insurance coverage ${ }^{70}$ among others, suggesting that these tort cases are becoming more fully integrated into the overall patterns of tort litigation.

\section{TORT ACTIONS AGAINST ASSAILANTS AS AN ALTERNATIVE TO THE CRIMINAL LAW: PROMISE AND PERILS FOR VICTIMS}

Obstacles to the use of criminal law to prevent unwanted sex have been well documented. As Steven Schulhofer writes with respect to the criminal process, even after "decades of intense scrutiny and repeated attempts at ambitious reform, our laws against rape and sexual harassment still fail to protect women from sexual abuse and overreaching." 71 A litany of evidence supports this conclusion. A minute fraction of rape cases result in prosecution. ${ }^{72}$ Even fewer result in conviction. ${ }^{73}$ And criminal law reforms seem not to have meaningfully affected these results. ${ }^{74}$ The

her to the dorm); Kravitz v. Beech Hill Hosp., 808 A.2d 34, 37 (N.H. 2002) (resident of rehabilitation facility assaulted other resident); Smith v. Four Corners Mental Health Ctr., Inc., 70 P.3d 904, 908 (Utah 2003) (one foster child assaulting another).

65. See, e.g., Kodiak Island Borough v. Roe, 63 P.3d 1009, 1011 (Alaska 2003) (showing assaults on developmentally disabled woman who suffered from cerebral palsy); Regions Bank \& Trust v. Stone County Skilled Nursing Facility, 49 S.W.3d 107, 110 (Ark. 2001) (showing semi-comatose quadriplegic patient who was assaulted); Doe v. Baum, 72 S.W.3d 476 (Ark. 2002) (assault on third-grader); Jeffreys v. Griffin, 801 N.E.2d 404, 478-79 (N.Y. 2003) (showing assault on woman under anesthesia).

66. See, e.g., Kennedy v. W. Sizzlin Corp., 857 So. 2d 71, 73 (Ala. 2003); Goins v. WalMart Stores, Inc., 800 So. 2d 783, 785 (La. 2001) (granting summary judgment on the basis that plaintiff had not demonstrated breach of duty by store security guards who learned that men fixing car in store parking lot had previously been arrested but did not pat them down or continue to observe them).

67. See, e.g., Saelzler v. Advanced Group 400, 23 P.3d 1143 (Cal. 2001).

68. See, e.g., Stahlecker v. Ford Motor Co., 667 N.W.2d 244 (Neb. 2003).

69. See, e.g., Doe v. Salvation Army, 835 So. $2 d 76$ (Miss. 2003).

70. See, e.g., Korhonen v. Allstate Ins. Co., 827 A.2d 833 (Me. 2003).

71. Steven Schulhofer, Unwanted Sex ix (1998).

72. See David P. Bryden \& Sonja Lengnick, Rape in the Criminal Justice System, $87 \mathrm{~J}$. CRIM. L. \& CRIMINOLOGY 1194, 1244-52 (1997).

73. See id. at 1251. These percentages may not be particular to rape; see Ronald Wright \& Marc Miller, The Screening/Bargaining Tradeoff, 55 Stan. L. Rev. 29, 30 n.1 (2002) (noting the tiny percentage of federal and state convictions that stem from criminal cases more generally).

74. See Schulhofer, supra note 71 , at 38-40; see also David P. Bryden, Redefining Rape, 3 BUFF. CRIM. L. REV. 317, 320 (2000) ("a growing body of social-scientific evidence 
difficulties relate not only to implementation of criminal law restrictions, but to core legal prohibitions themselves. As Schulhofer demonstrates, the criminal law, even as written, is inadequate to the task of protecting autonomous choice about sexual intimacy. ${ }^{75}$

\section{A. The Promise of Tort Law for Sexual Assault Victims}

Against this backdrop of failed criminal process, it is logical to think that victims might look elsewhere for a more congenial and effective forum. Ever since the mass media coverage of the O.J. Simpson criminal and civil cases, the general public has been aware that a person who commits a crime can be held liable in a civil court even after being found not guilty in a criminal trial. ${ }^{76}$ Sexual assault victims can file civil suit against attackers when the government is unable or unwilling to prosecute a criminal case or when the prosecutor does not prevail in proving the charges-as illustrated by the examples in Section I-or when the victim does not want to deal with government representatives. Some view this alternative use of tort actions as particularly sensible in the case of date or acquaintance rape, where prosecution is less likely. ${ }^{77}$

Although only a small percentage of current appellate court cases fit this alternative-use profile, there is reason to think that tort suits could be used in this way more routinely. Certainly, tort suits offer some significant procedural, practical, and doctrinal advantages for victims. One commonly-noted procedural distinction between the fora is the difference in the burdens of proof required. ${ }^{78}$ In criminal cases the prosecutor must establish "proof beyond a reasonable doubt." In civil actions, by contrast, the plaintiff need only show a "preponderance of the evidence." 79 Such differential burdens can be significant, as courts themselves recognize. ${ }^{80}$ Not only can torts suits be filed after criminal

indicates that, contrary to reformers' expectations, the much-heralded evidentiary reforms have had little impact on reporting, processing, and conviction rates in rape cases").

75. See generally SCHULHOFER, supra note 71.

76. Linda Greenhouse, $47 \%$ in Poll View Legal System as Unfair to Poor and Minorities, N.Y. Times, Feb. 24, 1999, at A12 (reporting American Bar Association survey that found that "a surprising 96 percent [of people polled] knew that a criminal defendant who is found not guilty can still be sued in a civil trial"and attributing that information to the O.J. Simpson trial).

77. See Warshaw, supra note 8, at 144 .

78. See, e.g., Cass R. Sunstein, Words, Conduct, Caste, 60 U. ChI. L. Rev. 795, 841 (1993) ("An important advantage of this route is that the 'reasonable doubt' standard of criminal law need not be met, and recovery can occur under the civil law's more lenient 'preponderance of the evidence' standard"); Holly J. Manley, Civil Compensation for the Victim of Rape, 7 CoOley L. Rev. 193, 199 (1990).

79. Ashmore v. Hilton, 834 So. 2d 1131, 1134 (La. Ct. App. 2003) (noting that because evidence from the victim alone is sufficient to prove rape in a criminal case, it is clearly sufficient in a civil case, in which the burden of proof is by a preponderance of the evidence).

80. In Doe v. Keller, 786 N.E.2d 422 (Mass. App. Ct. 2003), a man who had been raped by his roommates sought a permanent protective order against his attackers, which the court granted. Id. at 425 . The roommates appealed on the ground that a grand jury had heard the facts of the case and declined to indict them. Id. at 424. But the appellate court wrote the following 
acquittals, ${ }^{81}$ but at least one court held that treating a criminal acquittal as though it proved innocence was itself negligent. ${ }^{82}$

In addition to the lower burden of proof, tort actions provide a number of additional procedural advantages for victims. Unlike the criminal law, tort procedural protections are not weighted toward the defendant. In tort cases, the constitutional rights of defendants are rarely at issue. Consequently, the frequent due process challenges that arise in the criminal context, ${ }^{83}$ make only rare appearances in the tort law. ${ }^{84}$ Similarly, in the tort context unlike the criminal context, a victim can seek to discover and compel the defendant's testimony, or draw adverse inferences from the defendant's refusal to provide it. ${ }^{85}$ Moreover, unlike criminal cases in which the defendant is represented by counsel and the plaintiff is not, the defendant in a tort action has no right to free legal representation. ${ }^{86}$ While these differences may raise concerns that tort law procedural protections are too limited, the procedures nevertheless place plaintiffs and

[W]e find no merit in the defendant's claim with respect to the grand jury's failure to indict them. The question before the grand jury was whether there was probable cause to believe that [the roommates] had raped the plaintiff. The question before the district judge was whether, based upon a preponderance of the evidence, there was a continuing need for a restraining order under the [Massachusetts statute]. Different questions may result, as they did here, in different answers.

Id. at 425. In the tort context, see Dean v. Raplee, 39 N.E. 952, 954 (N.Y. 1895) ("If this was a criminal case, where the prosecution is bound to prove the charge 'beyond a reasonable doubt,' the appeal would be entitled to prevail. But here [in a tort action] a preponderance of proof is sufficient").

81. Smith v. Welch, 967 P.2d 727, 733 (Kan. 1998) (noting that civil action is not merged into criminal action).

82. Doe Parents No. 1 v. Dep't of Educ., 58 P.3d 545, 594 (Haw. 2003) (noting that the Department of Education which employed the teacher-pedophile who assaulted plaintiff "naively assumed, apparently without consulting its legal advisors, that [the teacher's previous] acquittal signified that a jury had determined that he was innocent beyond a reasonable doubt," that assumption was unreasonable, and the school's reinstatement of the teacher without further inquiry or restrictions was negligent).

83. See, e.g., State v. Lynch, 854 A.2d 1022, 1045 (R.I. 2004) (addressing adequacy of instruction to the jury about criminal law requirements on due process grounds).

84. See, e.g., Murray v. Developmental Servs., 818 A.2d 302 (N.H. 2003) (addressing evidentiary and trial practice issues under a standard affording discretion to the trial court); Frazier v. Badger, 603 S.E.2d 587, 573 (S.C. 2004) (upholding punitive damages award despite due process challenge).

85. Mitchell v. United States, 526 U.S. 314, 327-28 (1999) (This Court has recognized "the prevailing rule that the Fifth Amendment does not forbid adverse inferences against parties to civil actions when they refuse to testify in response to probative evidence offered against them," at least where refusal to waive the privilege does not lead "automatically and without more to [the] imposition of sanctions.").

86. See generally Katja Cerovsek \& Kathleen Kerr, Opening the Doors to Justice: Overcoming the Problem of Inadequate Representation for the Indigent, $17 \mathrm{GEO}$. J. LEGAL ETHICs 697 (2004); Jeanie Costello, Who Has the Ear of the King? The Crisis in Legal Services, 35 N.Y.L. ScH. L. Rev. 655 (1990); cf. Vibert v. Bd. of Educ. of Reg'l Sch. Dist. No. 10, 793 A.2d 1076, 1078 (Conn. 2002) (holding that school board had no duty to defend teacher accused of sexual assault despite statute requiring defense and indemnification in some circumstances). However, in one case a bankruptcy court ruled that the plaintiff's case against a convicted assailant was stayed because the defendant lacked funds to defend himself and no judgment was permitted to be levied against him because of the bankruptcy. Doe Parents No. 1, 58 P.3d at 567. 
defendants on more equal footing. Given the absence of free legal representation for alleged assailants in tort, it is not surprising to find that in many current cases the plaintiff settled with the assailant before trial, even when the case ultimately went to trial against third parties. ${ }^{87}$

Of particular procedural importance to victims who have pursued criminal as well as tort cases, in some instances tort liability may be established simply by noting a defendant's prior criminal conviction ${ }^{88}$ or guilty plea. ${ }^{89}$ In jurisdictions with collateral estoppel rules of this type, the plaintiff need only try the question of damages to the jury. ${ }^{90}$ Even when liability must be established in tort after a criminal conviction, in some circumstances the jailed defendant may not be permitted to appear at the trial. ${ }^{91}$ Civil use of other disciplinary findings is more complicated, but possible. $^{92}$ There is, of course, a worry here that courts may, at times, be too punitive toward unrepresented defendants. ${ }^{93}$

In substantive terms too, the tort law affords victims a number of advantages over the criminal law. Perhaps the most significant advantage is that there is no tort of rape. An occasional state statute creates a civil cause of action for sexual abuse. ${ }^{94}$ However, this is the exception rather

87. See, e.g., H.R.B. v. Rigali, 18 S.W.3d 440 (Mo. Ct. App. 2000) (in suit against priest, archbishop, and diocese stemming from sexual assault at church-run school, plaintiffs settled claims against priest for $\$ 25,000$ before trial, but proceeded to trial against the others); M.C. v. N. Ins. Co. of N. Y., 1 P.3d 673, 674 (Alaska 2000) (supervisory employee signed a confession of judgment assigning his rights to proceed against insurer on the condition that plaintiff not pursue the judgment against him).

88. See Smith v. Holmes, No. 03-02-00438-CV, 2003 WL 1561321, at *2 (Tex. App.Austin May 8, 2003, pet. denied); Charles Delbridge, Case Note, Civil Procedure-The Forest for the Trees: The Minnesota Supreme Court Considers the Collateral Estoppel Effect of Criminal Convictions in Illinois Farmers Insurance Co. v. Reed, 31 WM. MrTCHELL L. REV. 555 (2004); see also Seedon v. Bonner, 755 A.2d 823 (R.I. 2000) (discussing victim's rights statute which gives courts authority to enter conclusive civil judgments against convicted defendants if the victim wants this); Center for Law and Justice. University of Cincinnati College of Law, In Favor of "Trina's Law:" A Proposal to Allow Crime Victims in Ohio to Use the Criminal Convictions of the Perpetrators as Collateral Estoppel in Subsequent Civil Cases, 32 CaPITAL L. Rev. 351 (2003).

89. See Koenigstein v. McKee, No. 2002-CA-002212-MR, 2004 WL 41738 (Ky. Ct. App. Jan. 9, 2004) (holding that a defendant's guilty plea may have collateral estoppel effect in a civil action) (ordered not published, original on file with the author); Brandon Bortnor \& Douglas Miller, Procedural Issues, 40 AM. Crim. L. Rev. 933, 968-69 (2003). But see Clark v. Baines, 84 P.3d 245, 246 (Wash. 2004) (holding that Alford plea to assault with sexual motivation did not have collateral estoppel effect in subsequent tort action).

90. Koenigstein, 2004 WL 41738 , at *1.

91. See Smith, 2003 WL 1561321, at *2 (not permitting stepfather who had been jailed for sexual assault to attend trial when the risk of transporting him from prison was high and his criminal conviction and admissions "left no material issues of fact unresolved").

92. See Jeffreys v. Griffin, 801 N.E.2d 404, 407-10 (N.Y. 2003) (noting that factors for applying collateral estoppel from doctor's license revocation hearing to tort claim were met but that doctor should not have heen precluded from contesting liability).

93. Occasionally the judgments seem to reflect a tendency to heap blame on those already convicted. See Smith, $2003 \mathrm{WL} 1561321$, at *1 (entering an \$18.5 million damage judgment against a prisoner who was not permitted to be present at the trial).

94. See N.J. STAT. ANN. \& 2A:61B-1 (West 2005) (granting such a cause of action and permitting attorneys fees to be recovered in these cases); Hardwicke v. Am. Boychoir Sch., 845 A.2d 619, 627-30 (N.J. 2004) (applying New Jersey's child sexual abuse statute); see also, L.C.H. v. T.S., 28 P.3d 915, 918 (Alaska 2001) (noting that step-grandfather had been found civilly liable for "sexual abuse of a minor"). More typically, statutes that address 
than the rule. The absence of formal sexual abuse statutes does not mean that sexual assault victims in most states have no tort claims. It simply means that these parties must seek relief under more general causes of action that proscribe intentional and negligent harm, such as battery, ${ }^{95}$ assault, ${ }^{96}$ false imprisonment, ${ }^{97}$ outrage, ${ }^{98}$ seduction, ${ }^{99}$ violation of section $1983,{ }^{100}$ intentional infliction of emotional distress, ${ }^{101}$ invasion of privacy, ${ }^{102}$ negligent infliction of emotional distress, ${ }^{103}$ and other negligent

sexual assault in the civil law concern either the appropriate statute of limitations for such suits or evidentiary issues that arise in them. See, e.g., Cal. Ann. Evid. Code $\$ 1106$ (West 2006) (precluding evidence of plaintiff's prior sexual conduct in sexual harassment, sexual assault, excluding sexual battery cases); McCulloh v. Drake, 24 P.3d 1162, 1172 (Wyo. 2001) (holding that based on express statute of limitations exception for "sexual assault," action for sexual assault needed to be filed in four years, rather than under oneyear limit for assault and battery).

95. See, e.g., Jeffreys, 801 N.E.2d at 406.

96. See, e.g., id.

97. See, e.g., N. Sec. Ins. Co. v. Perron, 777 A.2d 151, 152 (Vt. 2001).

98. See, e.g., Smith v. Welch, 967 P.2d 727, 729 (Kan. 1998).

99. See, e.g., M.C. v. N. Ins. Co. of N.Y., 1 P.3d 673, 674 (2000).

100. See Alexander v. DeAngelo, 329 F.3d 912, 917-19 (7th Cir. 2003) (holding that officer's threats that woman would be jailed for forty years if she did not cooperate with sting operation that required her to pose as a prostitute and offer oral sex was rape, which constituted a serious battery and a violation of the Fourteenth Amendment, although qualified immunity applied to this new legal interpretation); Louviere v. Louviere, 839 So. $2 \mathrm{~d}$ $57,75-76$ (La. Ct. App. 2002) (reversing $\$ 1983$ judgment against city that failed to disclose negative employment information including an excessive force suit to subsequent employer on the ground that the evidence did not show deliberate indifference to victims rights); Billups v. Carter, 604 S.E.2d 414, 420 (Va. 2004) (reversing motions to dismiss $\$ 1983$ claims brought by prisoner who alleged sexual abuse by prison employee).

101. See, e.g., Nims v. Harrison, 768 So. 2d 1198, 1899 (Fla. Dist. Ct. App. 2000) (holding that a high school teacher could maintain an action against students based on student production and distribution of a newsletter laced with racial epithets that threatened to rape and kill her and her children); Delk v. Columbia/HCA Healthcare Corp., 523 S.E.2d $826,828-80$ (Va. 2000) (holding that a psychiatric patient could maintain intentional infliction of emotional distress action against facility that did not tell her that assailant had exposed her to possible HIV infection and deprived her of the information she needed to take precautions so as not to transmit it to her husband).

102. Allstate Ins. Co. v. Ginsberg, 863 So. 2d 156, 162 (Fla. 2003) (holding that unwelcome sexual comments and touching did not constitute invasion of privacy tort).

103. See, e.g., Doe Parents No. 1 v. Dep't of Educ., 58 P.3d 545, 552-53 (Haw. 2003) (permitting parents to recover for negligent infliction of emotional distress without predicate physical injury because trauma is self-evident to parents and child from a teacher's molestation of child in school); Baca v. Falgoust, 760 So. 2d 1279, 1280-81 (La. Ct. App. 2000) (permitting woman who had been raped and forced to perform oral sex at gunpoint to pursue negligent infliction of emotional distress claim when private investigator hired by client's attorney with respect to rape case continually asked her to perform oral sex). Often negligent infliction of emotional distress doctrines are tailored to physical injury cases, not cases in which there is a duty to protect the plaintiff from emotional harm itself. As such, in some cases, there is a disconnect between the doctrines of negligent interference with emotional distress tort and the realities of emotional distress in sexual assault cases. See, e.g., Brown v. Argenbright Sec., Inc., 782 A.2d 752, 760-61 (D.C. 2001) (asking whether sexual assault victim, whose picture may have been posted in store as a shoplifter, was "in the zone of physical danger" and concluding that the taking of a photograph did not involve physical danger). Often, when courts apply stilted rules in the negligent infliction of emotional distress cases, victims would be better served to assert other causes of action such as intentional infliction of emotional distress, and in Brown, perhaps, defamation. 
torts like malpractice ${ }^{104}$ and in third party cases claims like negligent hiring. ${ }^{105}$ Although not discussed at length in this piece, sometimes statutory claims ${ }^{106}$ or contract claims are also at issue. ${ }^{107}$

This ability to sue under more general causes of action appears to be one of the most significant advantages that victims enjoy in tort as opposed to criminal fora. A brief review of criminal cases decided by state appellate courts in the 2000 to 2004 time period suggests that criminal sexual assault statutes are very specifically written and rigidly applied. ${ }^{108}$ In criminal cases, prosecutors must prove beyond a reasonable doubt that the defendant committed each specific statutory provision with the required intentional state. ${ }^{109}$ Thus in some cases, the prosecutor must prove not only that the defendant sexually assaulted the plaintiff but that the assault was also for the purpose of sexual gratification. ${ }^{110}$ Similarly, criminal law cases necessarily delve into insufferable details about exactly which digit touched which orifice in order to establish that a particular offense has been committed.111 This sort of detailed focus on minute intricacies of sexual interactions stands in sharp contrast to the more fluid tort law. In battery, for example, a plaintiff need only show that she was harmed or offended by contact and that the defendant intended the contact to harm or offend.112 Thus the law of battery has been held to bar not only punches and kicks but even such slight offenses as cigarette smoke blown in another's face with an intent to offend. ${ }^{113}$

104. See, e.g., Mock v. Allen, 783 So. 2d 828, 833 (Ala. 2002) (holding that "where the alleged sexual misconduct occurs as part of a physician's examination and/or treatment of the patient, the conduct is considered to have occurred during the delivery of professional services, and is therefore cognizable as a medical-malpractice claim); Martinmaas v. Engelmann, 612 N.W.2d 600, 603 (S.D. 2000). But see Blier v. Greene, 587 S.E.2d 190 (Ga. Ct. App. 2003) (holding that, given the facts, a plaintiffs claim of sexual assault and battery against a clinic therapist did not involve the exercise of professional judgment, which is required for a professional or medical malpractice claim).

105. See, e.g., Majorana v. Crown Cent. Petroleum Corp., 539 S.E.2d 426, 427 (Va. 2000).

106. See, e.g., Seddon v. Bonner, 755 A.2d 823, 824 (R.I. 2000) (victim's rights statute that allowed victims to receive automatic compensatory verdicts but did not permit assessment of punitive damages).

107. See, e.g., L.A.C. v. Ward Parkway Shopping Ctr. Co., 75 S.W.3d 247, 250 (Mo. 2002) (asserting that the victim was a beneficiary of a mall security contract); Univ. of $S$. Miss. v. Williams, 891 So. 2d 160, 171 (Miss. 2004) (permitting question of breach of duty of good faith and fair dealing to go to jury based on professor's sexual assault of doctoral candidate).

108. See State v. Flynn, 855 A.2d 1254, 1261-63 (N.H. 2004) (addressing particular requirements of several different sexual assault statutes); State v. Denton, 149 S.W.3d 1 (Tenn. 2004) (interpreting statute prohibiting abuse of position of trust not to apply to physician who assaulted 17 year-old).

109. See, e.g., State v. Lynch, 854 A.2d 1022, 1045 (R.I. 2004) ("the Duc Process Claùse of the Fourteenth Amendment to the United States Constitution denies the state the power to deprive the accused of liberty unless the state proves every element necessary to constitute the crime charged beyond a reasonable doubt").

110. Id.

111. See State v. Flynn, 855 A.2d 1254, $1261-63$ (N.H. 2004) (discussing at length whether defendant's specific sexual acts amounted to cunnilingus and digital penetration).

112. See Hall v. McBryde, 919 P.2d 910, 914 (Colo. Ct. App. 1996).

113. Leichtman v. WLW Jacor Commc'ns, Inc., 634 N.E.2d 697, 699 (Ohio 1994). 
Traditional staples of the criminal law rape case, such as penetration, are simply not required in tort. And unlike the criminal law, no victim need show that a finger touched an unwanted place inside her vagina rather than outside her vagina in order to recover. ${ }^{114}$ Similarly, the element of force is irrelevant as long as the victim can prove the defendant had an actual intent to harm or offend. Consequently, some of the doctrinal hurdles for the victim to surmount in tort actions may be less cumbersome than those found in the criminal law. ${ }^{115}$

There is a risk that new statutes designed to aid sexual assault victims will import existing criminal-law problems into civil cases. For example, a New Jersey statute that creates a specific civil action for sexual abuse defines "sexual contact" to include touching "the victim's or the actor's intimate parts for the purpose of sexually arousing or sexually gratifying the actor." 116 This type of specific language would make defining intimate parts and introducing evidence of sexual gratification, among other topics, necessary issues of litigation in the civil context, as well as the criminal context. But as the common law stands without these statutory interventions, no such queries are important.

Using general causes of action like battery, state courts have reached a number of progressive results in rape cases. For example, the Washington Supreme Court permitted a woman to pursue a tort action against her husband for a rape that took place during the marriage ${ }^{117}$ even though Washington's criminal statute was not amended to prohibit marital rape until more than a decade later. ${ }^{118}$

Perhaps more important than even procedural and substantive advantages, civil actions present a number of practical advantages for victims. Because tort actions are filed by the victim herself, not on behalf of the state, victims control the decisions attendant to litigation, including when and whether to settle or dismiss a case. As such, victims can shape the litigation to meet their personal objectives. Tort litigation may be filed against defendants to obtain monetary damages. Although liability insurance is generally unavailable to pay for assailants' intentional torts, ${ }^{119}$ some assailants will have the assets and income from which to pay a judg-

114. Cf. State v. Flynn, 855 A.2d 1254, 1260-63 (N.H. 2004) (discussing the importance of this fact and evidence related to it in a criminal case).

115. See supra note 79.

116. N.J. Stat. AnN. § 2A:61B-1(2) (West 2005).

117. See Goode v. Martinis, 361 P.2d 941, 945 (Wash. 1961).

118. See State v. Bowen, 531 P.2d 837, 840 n.1 (Wash. Ct. App. 1975). A tort action can be filed based on marital rape in other states as well. See, e.g., In re Estate of Cheryl Peters, 765 A.2d 468, 474 (Vt. 2000) ("We reject entirely the notion that marriage creates any kind of implied 'blanket consent to sexual contact."'). Parents can also be sued for intentional torts when they sexually abuse children. See Herzfeld v. Herzfeld, 781 So. $2 \mathrm{~d}$ 1070, 1071 (Fla. 2001) (permitting son to sue adoptive father; parental immunity did not apply).

119. See Jennifer Wriggins, Domestic Violence Torts, 75 S. CAL. L. Rev. 121, 135-37 (2001) (noting the lack of insurance and asset availability for tort claims filed by victims of domestic violence and arguing for mandatory insurance coverage). 
ment or settlement, either directly or through garnished wages. ${ }^{120}$ Tort judgments against a spouse can also advantage the plaintiff when courts determine the distribution of marital assets during divorce proceedings. ${ }^{121}$

But even in the many cases in which victims cannot expect to recover monetary damages, tort suits can aid victims in obtaining non-monetary objectives such as an apology ${ }^{122}$ or the assailant's transfer to a different university, apartment complex, or job. ${ }^{123}$ These litigation objectives may be easier to achieve in tort law because the victim can directly bargain to drop her suit in return for the defendant's promise to meet her interests-the main function of settlement negotiations. This stands in marked contrast to the criminal context, in which it is generally considered unethical for a victim's attorney to suggest to the defense counsel directly that the victim drop criminal charges in return for the assailant's satisfaction of particular victim demands. ${ }^{124}$

One case that highlights the potential benefits of civil litigation for victims is Collins v. Carpenter. ${ }^{125}$ In that case, a mother brought suit against the man who allegedly molested and raped her minor daughter, who had learning disabilities. ${ }^{126}$ During the pendency of the litigation, the mother filed a motion for prejudgment attachment, which was granted by the court. ${ }^{127}$ As a result, the defendant was ordered not to sell his house. When the defendant nevertheless sold the house in violation of court order, the mother filed a fraudulent conveyance action against the home purchaser. An Ohio appellate court determined that the purchasers had constructive notice of the prejudgment attachment filed in the county recorder's office and therefore allowed the mother's fraudulent conveyance action to proceed. ${ }^{128}$ The mother later prevailed on this claim. ${ }^{129}$

120. See St. Paul Fire \& Marine Ins. Co. v. Engelmann, 639 N.W.2d 192, 201 (S.D. 2002); R.W. v. Schrein, 642 N.W.2d 505, 517 (Neb. 2002).

121. See htpp://www.neveragainfoundation.org (last visited Mar. 14, 2006).

122. Hopkins, Koss \& Bachar, supra note 10 , at 291.

123. Victim Rights Law Center, Victim Handbook.

124. Sarah M. Buel, Domestic Violence and the Law: An Impassioned Exploration for Family Peace, 33 FAM. L.Q. 719, 742 (1999); Jeffrey A. Ross, Ethical Issues Commonly Faced by Plaintiff's counsel in Sexual Harassment Cases, ABA CTr. FOR CLE NATIONAL INSTITUTE (1998) (noting that lawyer who offers to refrain from filing charges or agrees to drop charges in exchange for an acceptable settlement may "expose the attorney to charges of unethical conduct" as well as criminal charges including extortion and blackmail); William H.J. Hubbard, Comment, Civil Settlement During Rape Prosecutions, 66 U. CHI. L. Rev. 1231, 1250-60 (1999) (arguing that courts should apply bribery and witness tampering laws to pretrial settlements that induce rape complainants to avoid trial). However, prosecutors themselves may trade off victim compensation for a reduction or dismissal of criminal charges. See Gabriel J. Chin \& Richãrd W. Holmes, Jr., Effective Assistance of Counsel and the Consequences of Guilty Pleas, 87 CORnell L. Rev. 697, 718-23 (2002).

125. No. 02CA31, 2002 WL 31161099 (Ohio Ct. App. Sept. 30, 2002).

126. Id. at *1.

127. Id.

128. Id. at *3.

129. Collins v. Carpenter, No. 03-CA-99, 2004 WL 1047416 (Ohio Ct. App. Apr. 28, 2004). 
Although the appellate court's decision in Collins focuses on the mother's financial claim against the home purchasers (and presumably their property title insurer), it is easy to imagine that the case could provide both monetary and non-monetary benefits to the victim. Without need for the child victim to testify in court (the civil case was settled and no mention was made of a criminal suit), the mother was able to use the tort case to obtain financial remuneration for her daughter, to oust the accused molester from his home, and to prevent him from selling the house to people of his choice. ${ }^{130}$ Thus the alleged attacker could not simply sell the house to a relative and continue to reside in it after the change in ownership. ${ }^{131}$ Whether removing the alleged assailant from the neighborhood was part of the motivation in Collins or not, the case makes clear that under the civil law the victim and her family can, in some cases, force an attacker to leave-a potentially significant benefit to some victims and their families.

\section{B. Problems Persist for Sexual Assault Victims PROCEEDING IN TORT}

But the Collins case highlights not only the potential of viewing the tort law as an alternative to the criminal action but also one of the chief concerns in doing so. Although it might be good, indeed very good, for a victimized disabled child to live in a neighborhood free of her attacker and to obtain financial assistance to support her recovery, the civil remedy does little or nothing to protect the children living near the attacker after his change of address (or to protect this child from the assailant if he finds another home nearby). Consequently, the tort option could protect the child victim from future contact with her assailant and do so with less obvious trauma to the child-an outcome of tremendous significance for the individual child and family. However, from a public policy perspective, if the assailant is guilty of sexual assault, the tort action is less advantageous than a successful criminal prosecution. Criminal conviction could protect the public at large through incarceration or monitoring of the assailant. Thus, if criminal litigation would have been successful-if the child, police, and prosecutors would have pursued the case and obtained public remedies--using private litigation in lieu of criminal process could leave the public in worse stead.

But whether tort litigation would be a second-best solution to the criminal law depends on one crucial factor-what the criminal law would actually have done. In the vast number of criminal cases in which successful prosecution is unlikely, perhaps as in Collins, pursing civil remedies adds

130. Id.; cf. Doe Parents No. 1 v. Dep't of Educ., 58 P.3d 545, 566 (Haw. 2003) (not requiring child victims of sexual assault to testify in civil trial, as plaintiffs introduced transcripts of testimony from defendant's criminal prosecution).

131. Cf. Andrew Pollack, 2 Illegal Immigrants Win Arizona Ranch in Court Fight, N.Y. TIMES, Aug. 19, 2005, at A1 (noting that shortly after a default judgment was entered against rancher for harm to two border crossers, he gave his only substantial asset, his ranch, to his sister). 
to the sanctions against victimization rather than detracting from them. In those cases, civil actions would provide some public benefit or, at least, private benefit without much corresponding diminution of public interests. ${ }^{132}$

Even when tort suits complement criminal processes in meeting public objectives, however, tort actions present other procedural, practical, and substantive hurdles for victims. In procedural terms, a tort case can take five or more years to complete at the trial stage alone. ${ }^{133}$ This long-term litigation relationship with the defendant may be harmful to the victim's emotional or physical well-being. ${ }^{134}$ With respect to discovery, sexual assault victims may be subject to less-invasive discovery, because the defendant is not subject to incarceration and the victim is being represented by counsel. ${ }^{135}$ On the opposite side, sexual assault victims may be subject to broader discovery given the liberal discovery rules of the civil law and the fact that the plaintiff voluntarily initiated the case. ${ }^{136}$ While expert testimony regarding typical behaviors of sexual assault victims may be admitted in civil trials, ${ }^{137}$ the application of rape shield laws in civil cases is an important but unresolved issue in a number of states. ${ }^{138}$ In some tort litigation, the defendant may be able to use depositions and interrogatories to harass or embarrass the plaintiff. For example, with respect to the issue of damages, the defendant may be permitted to discover a number of personal details about the victim's sexual relationships before and after

132. There might be some diminution of public interests in Collins when the assailant moves away, because new neighbors will not have notice of the need to be aware of the potential for assault in the way that the old neighbors presumably did after the incident.

133. See Dominica C. Anderson \& Kathryn L. Martin, The Asbestos Litigation System in the San Francisco Bay Area: A Paradigm of the National Asbestos Litigation Crisis, 45 Santa Clara L. Rev. 1, 17-18 (2004) (discussing California legislation that was enacted "in response to a backlog of civil cases, many of which were taking five years to go to trial," and noting continuing problems with trial delays even after the legislation was passed).

134. Office of Justice Programs, U.S. Dep't of Justice, Legal Assistance for Victims Grant Recipients' Policy Guidebook 6 (2002) (stating that endeavors such as joint counseling may be a threat to the victim's safety and should not be pursued); Daniel W. Shuman, Making the World a Better Place Through Tort Law?: Through the Therapeutic Looking Glass, 10 N.Y.L. SCH. J. Hum. RTs. 739, 756-57 (1993) (expressing concerns about the effect of litigation delay on the victim's recovery).

135. Cf. Commonwealth v. Neumyer, 731 N.E.2d 1053, 1060 (Mass. 2000) (holding that unrepresented victim's counseling records were allowed to be subpoenaed despite a shield statute because of the defendant's significant interests in the records).

136. United States v. Degan, 517 U.S. 820, 825-26 (1996) (noting the broader discovery available in civil rather than criminal actions); $c f$. Doe v. Briscoe, No. CL02-499, 2003 WL 22748373 , at $* 1$ (Va. Cir. Ct. Apr. 24, 2003) (rejecting plaintiff's request to proceed pseudonymously on the ground that "it is the plaintiff herself who elected to initiate this action ... these are serious charges and fairness dictates that the plaintiff stand behind them, publicly").

137. L.C.H. v. T.S., 28 P.3d 915, 922 (Alaska 2001) (allowing expert testimony about child sexual abuse to rebut defendant's claim that plaintiff fabricated abuse claim).

138. See Jackson v. Heard, 591 S.E.2d 487, 487-89 (Ga. Ct. App. 2003) (admitting evidence that victim was at defendant's residence to provide sex for money because such evidence "would diminish the possibility that she feared rape," and could "make it less likely that [defendant] secretly slipped her a 'date rape' drug"). 
the attack. ${ }^{139}$

Perhaps the largest practical hurdle to direct litigation by the victim against the attacker is access to legal services. As with all legal services, most are prohibitively expensive to the majority of Americans. ${ }^{140}$ Though many tort plaintiffs can obtain legal services on a contingency basis, such representation is difficult to obtain when the expected financial recovery is slight, as would often be the case in lawsuits against the alleged assailant directly. In addition, traditional legal service programs have been unavailable to rape victims and public funding, such as legal assistance to victim grants, currently may not be used to pursue tort actions. ${ }^{141}$

Last, but certainly not least, victims may face a number of substantive doctrinal hurdles similar or in addition to those they face in the criminal courts. Specifically, thorny issues of consent remain in the civil context and are intermingled with issues surrounding the defendant's subjective intent to harm or offend. In addition, issues of damages and defenses pose new hurdles for victims. Tort statutes of limitations for intentional torts can be short, and defenses, such as contributory fault, that are barred in criminal and tort cases alike, threaten to reenter tort law. ${ }^{142}$

The case of consent provides a useful example of the shared difficulties in criminal and civil case law. Like the troubling criminal law cases in which courts ignore coercive conditions surrounding consent to sex, ${ }^{143}$ in tort law too, courts have at times disregarded even the most coercive of circumstances. ${ }^{144}$ The recent Indiana Supreme Court opinion, Robins $v$.

139. See, e.g., Birkner v. Salt Lake County, 771 P.2d 1053, 1061 (Utah 1989) (holding that with respect to a woman who had been sexually assaulted by her therapist, defense counsel's questions about whether victim's former husband ever kissed her and touched her breast when they engaged in sex while married were appropriate because "the jury was entitled to consider [plaintiff's] prior experience in assessing damages" and finding it "difficult to understand" why the plaintiff thought this evidence was improper).

140. David Wilkins, Race, Ethics, and the First Amendment: Should a Black Lawyer Represent the Klan, 63 GEO. WASH. L. REV. 1030, 1034 (1995) (addressing lawyers' responsibilities in light of the problem of lack of access to legal services).

141. Office on Violence Against Women, U.S. Dep't Of Justice, Legal Assistance for Victims Grant Program, Fiscal Year 2003 Solicitation 3 ("Grant funds can not be used to support legal representation in the following areas: [t]ort cases, [c]hild sexual abuse cases, [c]ases involving the child protective services, [v]ictim service employee cases"); see also, Lois H. Kanter, Invisible Clients Exploring Our Failure to Provide Civil Legal Services to Rape Victims, 38 SUFFOLK U.L. REv. 254 (2005) (discussing the reality that "traditional legal services programs, law school clinics, and bar association pro bono projects have never served rape victims").

142. There is some academic argument about whether contributory negligence arguments do and should reenter the criminal law as well. See generally Vera Bergelson, Victims and Perpetrators: An Argument for Comparative Liability in Criminal Law, 8 BuFF. L. REv. 385 (2005).

143. Stephen J. Schulhofer, Rape in the Twilight Zone: When Sex is Unwanted But Not Illegal, 38 Suffolk U. L. Rev. 415, 416-17 (discussing People v. Warren, 446 N.E.2d 591 (III. App. Ct. 1983)).

144. See, e.g., State v. Markway, 353 S.W.2d 727 (Mo. 1962) (holding that minor female prisoner who had sexual intercourse with jailer had no suit against jailer, bonding company, or sheriff based on evidence that she consented to intercourse). 
Harris, ${ }^{145}$ is illustrative. In Robins, a female county jail inmate charged that she had been sexually assaulted by a deputy at the jail. In a criminal action against him, the deputy admitted to sexual contact and pleaded guilty to misdemeanor official misconduct. ${ }^{146}$ In a tort suit stemming from the same conduct, the deputy argued that the inmate consented to sex. The state appellate court ruled that the consent defense should have been barred. ${ }^{147}$ Although the case was settled before review, the Indiana Supreme Court nevertheless chose to affirm the appellate court's decision "except as to the availability of consent as a defense to the claim of battery," leaving open the possibility that a jailer might raise the inmate's consent to sex as a defense in future cases. ${ }^{148}$

In dissent, Justice Sullivan argued that the appellate court had been correct-consent should not furnish a defense where a detainee is involved.149 In support of this assertion, the dissent invoked the court of appeals' public policy argument: Indiana law does not permit consent to serve as a defense to a criminal sexual assault claim involving a detainee. "Given [the plaintiff's] general lack of autonomy as an inmate, it would be incongruous to withhold the defense of consent in the criminal context, but to allow [the jailer] the defense in a civil claim."150 In light of the coercive conditions of the detention, the dissent argued that public policy precluded the defense in both criminal and civil cases. Since these arguments were made in dissent, they demonstrate that, at least with respect to the issue of consent, in some cases Indiana sexual assault victims are no better off, and may be worse off, proceeding in Indiana's civil rather than criminal courts.

It is easy to argue that the Indiana Supreme Court's reasoning violates ordinary tort principles. Power inequalities and duress have long been recognized as forces that obviate consent in the tort law. ${ }^{151}$ Nevertheless, the Robins case makes clear that consent is an issue to be reckoned with in tort cases based on sexual assault, just as it is with respect to criminal suits.

In fact, at times the consent issue has taken troubling turns in tort law that would not have been possible in the criminal law. Specifically, in one recent New Hampshire Supreme Court case, Kravitz v. Beech Hospital, ${ }^{152}$ the existence of consent was determined not by a review of the testimony and evidence in the case but rather based on the jury's findings with respect to apportionment and damages. In Kravitz, a fourteen-year-old girl who was being treated at a drug and alcohol treatment facility alleged

145. 769 N.E.2d 586 (Ind. 2002).

146. Id. at 587 .

147. Id.

148. Id.

149. Id. at 587-88 (Sullivan, J. dissenting)

150. Id. at 588 (Sullivan, J. dissenting).

151. See Dan B. DobBs, The Law of Torts $\S 102$, at 236-41 (examining circumstances in which consent obtained by abuse of power or position might be deemed ineffective as a matter of policy).

152. 808 A.2d 34 (N.H. 2002). 
that she had been raped by an eighteen-year-old convicted sex offender staying in the same facility. ${ }^{153}$ "[T]he central question at trial was whether the sexual activity was consensual." 154 The girl testified that the sexual activity was not consensual. It is not clear from the opinion whether the eighteen-year-old defendant testified with respect to the issue of consent at all. However, his liability was established through a default judgment. After a ten-day trial the jury completed a verdict form finding both the alleged rapist and the drug treatment facility liable. ${ }^{155}$ Despite this finding of liability, the jury, which had been allowed to hear evidence of the girl's prior consensual sexual contact with three Jamaican men despite a pretrial motion to the contrary, assigned $\$ 130$ damages to the victim, ${ }^{156}$ which the trial court then reduced to zero. ${ }^{157}$ The jury also awarded $\$ 13,672$ in damages to the mother-reimbursement for the daughter's stay at the treatment facility. Between the liable defendants, the jury apportioned one hundred percent of the fault for the assault to the treatment facility that had given the prior sex offender access to the girl.

On appeal to the New Hampshire Supreme Court, the court agreed that "no party disputes that it is unreasonable for a jury to find that a fourteen-year-old child had been raped, but award her zero damages." 158 However, rather than use this concern as a reason to remand for a new trial on the issue of damages ${ }^{159}$ or for a new trial based on conflicting liability and damage verdicts, the appellate court held as a matter of law that the girl had not been raped. According to the court, despite the finding of liability, "the jury had not found that non-consensual sexual conduct had occurred." 160 Thus the court used the extremely low damage award and assignment of institutional fault to conclude that "the sexual activity had been 'volitional on the part of both parties." "161

Although it might seem rational for the court to assume that if a rape had occurred, the jury would have assigned the rapist the lion's share or at least some of the fault, jury comparative apportionment decisions belie that assumption. Even in cases in which the defendant was guilty of extreme fault, as in an apparently premeditated homicide, a jury awarded only $25 \%$ of the fault to the murderer himself and assigned the remaining $75 \%$ of the fault to the negligent 911 operator who misclassified the

153. Id. at $37-38$.

154. Id. at 38 .

155. Id. at 37-38.

156. Id.

157. Id. at 38 . The trial court's theory was that the jury could have reasonably concluded that damages had not been established.

158. Id. at 41 .

159. See A.R.B. v. Elkin, 98 S.W.3d 99, 105 (Mo. Ct. App. 2003) (appellate court remanded case for new damages determination when trial court found sexual abuse against children but awarded no damages to female victim and only $\$ 100$ damages to male victim).

160. Kravitz, 808 A.2d at 42.

161. Id. at $42-43$. 
plaintiff's emergency call as a non-priority call. ${ }^{162}$ As such, low percentages of fault assigned to the intentional tortfeasor may have a number of meanings besides no wrongful conduct by the tortfeasor, including a greater likelihood that appropriate conduct by the negligent-tortfeasor would have averted the harm.

In reaching the conclusion that the jury's apportionment necessarily reflected the plaintiff's consent to the sexual conduct despite the jury's finding of liability, the New Hampshire Supreme Court, not generally considered a finder of fact, determined that the girl had consented to sexual contact-not based on consideration of the evidence in the case-the girl's testimony, the assailant's testimony, or the testimony of anyone else present during or after the incident-but based on its opinion of the jury's inadequate damage award. ${ }^{163}$ While the court's conclusion is as surprising as it is unusual, the case highlights the difficulty that the consent issue can pose in tort law, even when the jury concludes that the elements of the tort case have been met.

Problems of consent in the civil context, can present themselves not only as consent issues per se, but also as problems for the plaintiff in proving the defendant's subjective intent to harm or offend (one of the prima facie elements of the battery case). In battery cases involving sexual relationships, the question of consent is related to the intent question-did the defendant intend to commit a harmful or offensive touching? Even if a reasonable person would not have thought that the plaintiff was consenting to sexual contact-the standard for consent ${ }^{164}$ if the defendant himself actually but unreasonably believed that the plaintiff was consenting, many though not all state courts would not hold the defendant liable in tort. ${ }^{165}$ To use tort law to prevent physical contact

162. See Hutcherson v. City of Phoenix, 961 P.2d 444, 451-52 (Ariz. 1998); see also Ellen M. Bublick, The End Game of Tort Reform: Comparative Apportionment and Intentional Torts, 78 Notre Dame L. Rev. 355, 385 n.131 (2003) (citing cases in which the negligent party was assigned more of the fault than the intentional tortfeasor) [hereinafter Bublick, The End Game].

163. Kravitz, 808 A.2d at 42 . The court's conclusion may also have relied on an improper attorney affidavit that the court said should not have been considered.

164. See supra note $140, \S 596$ at 218 (noting that "either actual or apparent consent is effective to relieve the actor of responsibility").

165. Thus, if defendant argued that while a reasonable person would have realized that the plaintiff was not consenting to sexual contact, he did not, if the jury believed him, in many jurisdictions his conduct would not constitute battery (as battery often requires a subjective intent to harm or offend). See White v. Muniz, 999 P.2d 814, 817 (Colo. 2000) (discussing the dual intent standard as well as jurisdictions that do not require it). But see Wagner v. State, 122 P.3d 599, 603 (Utah 2005) (insisting that the only intent required in battery is intent to make bodily contact, though harm or offense must result in fact); Jeffreys v. Griffin,801 N.E.2d 404, $408 \mathrm{n} .2$ (N.Y. 2003) (quoting pattern jury instructions that read "intent required for battery is intent to cause a bodily contact that a reasonable person would find offensive"); In re M.T.S., 609 A.2d 1266 (N.J. 1992). Requiring this more limited intent in battery cases could extend victims' recovery in battery cases but could also obliterate the distinguishing features of intentional and negligent torts. See RestatemENT [Third] of TorTs: Liability for Physical Harms $\$ 1$ (2005) (requiring subjective intent to harm or offend for intentional torts). The problem of rape when a reasonable person would understand that the victim was not consenting but the defendant did not has been discussed in the criminal forum. See Susan Estrich, Real Rape (1987). 
that a reasonable person would have recognized as harmful, offensive, or nonconsensual, state courts or legislatures would need to create legal rules proscribing intentional touchings that are reckless or negligent with respect to harm or offense to the person touched. These rules currently do not exist in many jurisdictions. ${ }^{166}$

Consent and the related issue of a defendant's subjective intent are not the only substantive areas of tort law that present challenges to sexual assault victims. Even once the assault is proved, courts have questioned whether sexual assault victims have actually suffered damages. Although in a few cases high punitive damages have been assessed against an assailant, ${ }^{167}$ other courts or juries awarded no damages at all. ${ }^{168}$

A number of defenses may also impede victim recovery. For example, in the tort context, it has been held that a doctor who assaults his patients may be entitled to take advantage of a tort reform statute for medical malpractice, even though the plaintiff has pleaded an intentional tort rather than malpractice itself. ${ }^{169}$

Similarly, statutes of limitation have been a barrier to some victim

166. See Kodiak Island Borough v. Roe, 63 P.3d 1009, 1015 (Alaska 2003) (rejecting defendants' request to instruct on negligence or recklessness on the ground that if the jury had found the defendants liable "for anything less than an intentional touching, they would not have been liable for assault"); Weldon v. Rivera, 301 A.D.2d 934, 935 (N.Y. App. Div. 2003) (holding that there is no precedent under New York law for a tort of negligence or recklessness in the context of rape). But see Martinmaas v. Engelmann, 612 N.W.2d 600, 603 (S.D. 2000) (holding that rape by doctor in the course of an examination constituted "malpractice," a tort that sounds in negligence). Cf. Ian Ayres \& Katherine K. Baker, A Separate Crime of Reckless Sex, 72 U. CHI. L. REv. 599 (2005) (proposing a crime of reckless sex, in part to stem acquaintance rape and in part to stem sexually transmitted disease).

167. See Smith v. Holmes, No. 03-02-00438-CV, 2003 WL 1561321, at *1 (Tex. App.Austin May 8, 2003, pet. denied) (rendering an $\$ 18.5$ million default judgment against jailed stepfather).

168. In A.R.B. v. Elkin, 98 S.W.3d 99 (Mo. App. 2003), for example, a son and daughter sued their father for assault and battery stemming from sexual abuse. Although the trial judge found the father liable, the court awarded only nominal damages to the son and no damages to the daughter who, in the court's judgment, had not been physically harmed. Id. at 103. On appeal, the court held that at a minimum, both plaintiffs should have been awarded nominal damages. In addition, the appellate court held that the trial court should have considered awarding additional compensatory damages for pain, humiliation, and mental anguish, and possibly even punitive damages. Id. at 104-05; see also Kravitz v. Beech Hosp., 808 A.2d 34, 42 (N.H. 2002) (examining jury finding of third-party liability based on sexual assault in which the jury assigned victim zero damages); Doe v. N. Panola Sch. Dist., 906 So. 2d 57, 62 (Miss. Ct. App. 2001) (finding insufficient evidence to support pain and suffering damages to moderately retarded student who could not communicate clearly the level of stress she suffered as a result of rape).

169. See, e.g., Mock v. Allen, 783 So.2d 828, 832 (Ala. 2000) ("Although the AMLA applies only to medical-malpractice actions, a plaintiff cannot avoid application of the AMLA by 'creative pleading.' This Court has consistently held that it is the substance of the action, rather than the form, that is the touchstone for determining whether an action is actually one alleging medical malpractice."). But see Buck v. Blum, 130 S.W.3d 285, 287-88 (Tex. 2004) (requiring that plaintiff, who alleged that neurologist placed his penis in her hand, comply with Texas Medical Liability Act requirements with respect to claims against medical clinic's other neurologists and co-owners, but not necessarily with respect to the assaulting physician). By contrast, when professional liability insurance coverage is concerned, courts often say that plaintiffs cannot use creative pleading to turn a sexual assault claim into one for malpractice. See Ross v. Home Ins. Co., 773 A.2d 654 (N.H. 2001). 
suits. Statutes of limitation for intentional torts are often short, ${ }^{170}$ though they may afford children additional time to file a cause of action once they reach the age of majority, ${ }^{171}$ be lengthened by the discovery doctrine, ${ }^{172}$ be tolled by fraudulent concealment of material facts, ${ }^{173}$ or be waived by defendants who fails to raise those defenses. ${ }^{174}$ When short statutes of limitation were applied in rigid fashion, at least one victim was barred from filing suit against the attacker even when she learned the attacker's identity belatedly through no fault of her own.

In Grimes v. Suzukawa, ${ }^{175}$ a Virginia Supreme Court case, the plaintiff had been raped by a masked assailant who broke into her apartment. ${ }^{176}$ The assailant could not be identified and evaded capture by the police for over seven years. ${ }^{177}$ When the assailant was later apprehended and confessed to the crime, the plaintiff filed suit. In her civil suit, the victim argued that the state's short statute of limitations should be tolled because she had no way to identify her assailant before he confessed his crimes to police. Under the state's tolling provision, the statute of limitations could be tolled when "the filing of an action is obstructed by the defendant's ... (ii) using any ... direct or indirect means to obstruct the filing of an action." 178 Rather than conclude that the rapist had indirectly obstructed the plaintiff's filing of an action by wearing a mask and fleeing the scene of the crime, the Virginia Supreme Court refused to toll the statute. According to that court's hyper-technical reading of the statute, the rapist's "use of a mask was intended to conceal his identity and not

170. See, e.g., Blier v. Greene, 587 S.E.2d 190 (Ga. Ct. App. 2003) (discussing five-year statute of limitations that applied to sexual assault case); Billups v. Carter, 604 S.E.2d 414, 419 (Va. 2004) (noting one-year limitations period for assault and battery); Jennifer Wriggins, Domestic Violence Torts, 75 S. CAL. L. REv. 121, 139-40 (2001) (noting short statute of limitations for intentional torts and the difficulties this raises for victims of domestic violence). But see McCulloh v. Drake, 24 P.3d 1162, 1171-72 (Wyo. 2001) (holding that based on express statute of limitations exception for "sexual assault," action for sexual assault needed to be filed in four years, rather than under one-year limit for assault and battery).

171. See, e.g., L.C.H. v. T.S., 28 P.3d 915, 920 (Alaska 2001) (holding that child sexual assault victim could recover on claims that were brought within the statute of limitations when she "remembers but does not appreciate until later the causal connection between the [abuse] and its psychological or emotional effect" and that credibility of testimony is for the jury to hear and decide); Clay v. Kuhl, 727 N.E.2d 217, 217 (Ill. 2000) (statute of limitations barring claim of childhood sexual assault against clergyman and religious order); Parks v. Kownacki, 737 N.E.2d 287, 294 (Ill. 2000) (holding that statute of limitations began to run when parishioner, who was sexually assaulted as a minor, reached the age of majority even though she alleged that she did not make the connection between the sexual relationship and her injuries until later); Martin v. Howard, 784 A.2d 291, 299 (R.I. 2001) (holding that statute of limitations had run despite adult parishioner's claim that she did not appreciate the full nature and extent of her injuries).

172. See, e.g., Hearndon v. Graham, 767 So. 2d 1179 (Fla. 2000) (permitting plaintiff to sue step-father).

173. Miller v. Monongali County Bd. of Educ., 556 S.E.2d 427 (W. Va. 2001).

174. See Palacios v. Robbins, No. 04-02-00838-CV, 2003 WL 21502371, at *2 (Tex. App.-San Antonio Jul 2, 2003, pet. denied) (holding that husband, who failed to request a jury finding on his statute of limitations defense, had waived the issue on appeal).

175. 551 S.E.2d 644 (Va. 2001).

176. Id. at 331 .

177. Id. at 332 .

178. Id. at 331 . 
intended to obstruct her filing of an action."179 Given this extremely narrow reading of the statute's tolling provision, the plaintiff was not permitted to pursue her civil claim for assault and battery against the assailant even after he was identified. ${ }^{180}$

Other defenses can be fraught with peril for victims as well. Although traditionally intentional tortfeasors such as rapists were not allowed to defend based on the victim's contributory fault, a few courts have permitted victim comparative-fault defenses to even the most egregious intentional torts. This practice has become a more open question with a number of state courts' and legislatures' adoption of comparative apportionment rather than comparative negligence statutes. ${ }^{181}$ Permitting comparative fault to serve as a defense to an intentional tort raises the alarming prospect that an intentional tortfeasor, like a rapist, can diminish his legal responsibility to the victim by blaming her for the rape. For example, in one Louisiana case, a thirteen-year-old girl was found twelve percent liable for her own gang rape, because she went with the group of boys to drink some beer. ${ }^{182}$ Although Louisiana enacted a statute that would now prevent this result, ${ }^{183}$ that statute is imperfect, ${ }^{184}$ and few states have yet enacted similar limitations. ${ }^{185}$

While states generally continue to preclude an intentional tortfeasor defendant, like a rapist, from reducing his responsibility for damages based on a victim's negligence, ${ }^{186}$ legal authorities have failed to ensure that a holding like Louisiana's will not be replicated. ${ }^{187}$ For example, the Restatement Third of Torts: Apportionment of Liability took "no position on whether a plaintiff's negligence is a comparative defense to intentional torts." 188 While the Restatement provides courts with "flexibility to fashion appropriate special rules for victims of intentional torts," 189 it

179. Id. at 332 .

180. Id.

181. See generally Bublick, The End Game, supra note 162 (researching recent cases and finding trend toward comparing intentional and negligent torts of defendants, not of plaintiff and defendant, but noting the possibility for spillover particularly from courts that speak in broad terms and are not aware of different contexts).

182. Morris v. Yogi Bear's Jellystone Park Camp Resort, 539 So. 2d 70, 72 (La. Ct. App. 1989).

183. LA. Civ. Code ANN. art. 2323(c) (West 2005) ("If a person suffers injury, death, or loss as a result partly of his own negligence and partly as a result of the fault of an intentional tortfeasor, his claim for recovery of damages shall not be reduced").

184. Even in Louisiana, the percentage shares are still assigned between assailants, victims, and others, Louviere v. Louviere, 839 So. 2d 57, 76 (La. Ct. App. 2002) (upholding jury assignment of fault to estranged wife whose husband came to her workplace on a crime spree, held her hostage, and sexually assaulted her), although the assailant may not be permitted to take advantage of a reduction in damages from them.

185. Bublick, The End Game, supra note 162.

186. Id at 390-91 (discussing court's broad language about "comparing intentional and negligent fault" but finding that court comparisons rarely arise between intentional tortfeasor defendants and negligent plaintiffs absent special cases such as high-culpability plaintiffs, or low-culpability defendants).

187. See Restatement (Third) of Torts: Apportionment of Liability $\S 1 \mathrm{cmt}$. c.

188. Id. (specifically citing Morris).

189. Id. $\S 3 \mathrm{cmt}$. $\mathrm{d}$ (proposing plaintiff no-duty rules). 
does not provide an imperative for them to do so. I have elsewhere argued that courts and legislatures should follow the lead of certain jurisdictions to make victim comparative-fault defenses off-limits in rape and other intentional tort cases. ${ }^{190}$ The Washington Supreme Court's limitation on the victim's duty is an exemplar in this area. ${ }^{191}$

Given the varied substantive concerns in tort actions against alleged assailants themselves, the tort law is appropriately viewed as a forum with a variety of distinct advantages for victims, but also one in which difficulties remain. Given this unidealized reality, civil litigation still may serve a valuable function-in particular, allowing the victim to direct this evenly matched and flexible inquiry to seek remedies in her own interests through the settlement process or trial itself. However, it would be wrong to suggest that this shift might not entail social costs or that tort fora will be a panacea for victims' concerns.

\section{CIVIL-LAW RESPONSIBILITY FOR RAPE: BEYOND ASSAILANTS}

If third-party actions were not viable in tort, lawyers would not have pursued so many cases. The large number of appellate court opinions concerning third-party liability to sexual assault victims testifies to both the viability of these claims, and the flux and uncertainty that pervades this area of law. These uncertainties span a broad number of legal questions. I have clustered the most pervasive and important issues that arise in the case law into four categories-which actors are responsible for taking care to prevent sexual assault, the appropriate measure of damages for victims of sexual assault and the way in which those damages are apportioned among multiple actors, the availability of compensation such as insurance to cover victim losses, and the protection of victim privacy within and through the tort process. Each of these four issues will be examined in turn.

\section{A. Responsibility for Rape Prevention}

Which actors are responsible for using care to prevent rape? The issue of appropriate responsibility is an open one. Perhaps the most litigated issue in the appellate cases is whether and to what extent third parties must take reasonable care to prevent sexual assault. Courts' answers vary widely, revealing perhaps why appellate litigation is so prevalent, and why further discussion of these issues is essential.

190. See Ellen Bublick, Citizen No-Duty Rules: Rape Victims and Comparative Fault, 99 Colum. L. Rev. 1413 (1999) [hereinafter Bublick, Citizen No-Duty Rules]; see also LA. Civ. Code AnN. art. 2323(c) (West 2005) (barring comparative fault claims filed by assailants); Hutchinson v. Luddy, 763 A.2d 826, $847-49$ (Pa. 2001) (barring comparative fault claims pursued by third parties).

191. See Christensen v. Royal Sch. Dist. No.160, 2005 WL 3346205, at *5-6 (Wash. 2005) ("we hold as a matter of public policy that children do not have a duty to protect themselves from sexual abuse"). 
In doctrinal terms, issues of third-party responsibility for sexual assault generally arise in two areas of the negligence case-duty and proximate cause. ${ }^{192}$ A tort duty can be created in a number of circumstances involving special relationships. ${ }^{193}$ When created, the duty involves use of reasonable care to protect against foreseeable harms but not others. ${ }^{194}$ As such, a frequent issue in the tort law is when rape is foreseeable. The case law vacillates between broad rulings about rape as a foreseeable fact of modern life ${ }^{195}$ and rape as an unlikely event that cannot be foreseen unless committed by the same person in exactly the same situation just before. ${ }^{196}$

Situational factors play an important role in these foreseeability determinations. For example, two frequent lines of litigation involve employers' responsibility for sexual assaults committed by their employees and property owners' liability for sexual assaults that take place on their property. Courts have taken a far broader view of the foreseeability of sexual assault in the premises cases than in the employment cases. This division is perhaps ironic in that employers are thought to control their employees and, in some contexts, are even vicariously liable for their employees' conduct, ${ }^{197}$ unlike the more distant relationship of landowner and trespasser or even landowner and invitee. ${ }^{198}$

In the premises liability context, courts have found sexual assaults foreseeable even in the absence of directly-similar prior assaults. Courts have held that violent crimes of a different variety and in a different location can make rape foreseeable on a given property. ${ }^{199}$ In addition, evidence of prior sexual assaults by strangers can suggest the foreseeability of sub-

192. Third-party liability issues are typically presented in terms of negligence, although claims of recklessness have been pursued. In a negligence action, a victim's claim must allege that the defendant had a duty to use reasonable care for the victim, failed to do so, and that but for that failure of care the victim would not have been assaulted and suffered consequent harm. The victim must also allege that the resultant harm was the type risked by the defendant's failure of care.

193. Restatement (Second) of Torts \$§ 314(a), 315(a), 321, 323 (1965).

194. The level of generality at which the duty question is asked can also be significant to the outcome of a case. See Pathways, Inc. v. Hammond, 113 S.W.3d 85, 94 (Ky. 2003) (Stumbo, J., dissenting) (objecting to court's detailed specification of the duty issue and instead wanting the court to ask whether the agency owed its clients duty of reasonable care, rather than duty to undertake a particular act).

195. See Stanton v. Univ. of Me. Sys., 773 A.2d 1045, 1048-50 (Me 2001).

196. See Reed v. Kelly, 37 S.W.3d 274, 277 (Mo. Ct. App. 2000).

197. See Riviello v. Waldron, 391 N.E.2d 1278 (N.Y. 1979) (holding employer liable to customer injured when cook-employee flipped a knife).

198. See Munroe v. Universal Health Servs., 596 S.E.2d 604, 606 n.3 (Ga. 2004) (holding that "the policy reasons for that higher standard in premises liability cases have no application to negligent hiring/retention cases" for the ironic reason that premises owners have no control over "illegal behavior of unknown assailants who come onto its property" while employers have "exclusive control" over hiring and opportunities to harm potential plaintiffs).

199. See Doe v. Wal-Mart Stores, 558 S.E.2d 663, 673 (W. Va. Ct. App. 2003) (holding that "similar incidents" to rape included a variety of criminal acts that occurred in parts of four states). 
sequent acquaintance rapes. ${ }^{200}$ In fact, in the premises context, an acquaintance rape may be foreseeable absent evidence of any prior assaults. For example, in Stanton $v$. University of Maine System, ${ }^{201}$ a case involving acquaintance rape in a college dorm room, the court held that rape is foreseeable on college campuses, notwithstanding the university's assertion that it had received no report of a rape or sexual assault in the preceding five years. As such, a jury was permitted to examine whether the university had breached its duty of care. ${ }^{202}$

In contrast to this broad view of foreseeable sexual assault in premises liability cases, ${ }^{203}$ court decisions in the employment context have been far more circumspect. ${ }^{204}$ In the employment cases, courts typically do not ask whether employers knew of prior crimes or rapes by employees in general or in the types of work situations in which their employees are involved, for example door-to-door sales. ${ }^{205}$ Instead, to show that sexual assault was foreseeable in the employment context, plaintiffs often have to show that the employer was aware of prior misconduct by the particular employee accused of abuse. ${ }^{206}$ Exactly what kind of prior misconduct is enough to make a subsequent sexual assault foreseeable is a question raised in a number of cases. If the employer knew or should have known that the employee committed a previous rape, a subsequent rape will typically be considered foreseeable - triggering a duty. ${ }^{207}$ But at times, even the employer's knowledge of prior assaults or sexual assaults by the particular employee did not make the subsequent sexual assault foreseeable

200. In L.A.C. v. Ward Parkway Shopping Center, 75 S.W.3d 247 (Mo 2002), a twelveyear-old girl was raped in a shopping mall catwalk by a boy she had met the previous week. Although a friend tried to summon two security guards to the scene, they dismissed her and made no investigation. Id. at $250-51$. When the court examined, as a part of its duty analysis, whether the rape was foreseeable, it declined to adopt a formal "similar incidents" or "totality of the circumstances" test. Id. at 256. Still, when addressing how similar "similar incidents" of crime had to be to make future rapes foreseeable, the court decided that a plaintiff need not prove "identical crimes in identical locations." Id. at 259. Prior violent crimes by strangers made other violent crimes, even by acquaintances, foreseeable as well. Id.

201. 773 A.2d 1045 (Me 2001).

202. Id.

203. But see Goins v. Wal-Mart Stores, Inc., 800 So. 2d 783 (La. 2001) (rejecting premises liability claim when security guards hired by store stopped men who later raped plaintiff, but did not continue to observe them).

204. See, e.g., Monroe v. Universal Health Servs., 596 S.E.2d 604, 608 (Ga. 2004) (holding no negligent hiring or retention of nursing home employee who sexually assaulted plaintiff).

205. Rogers v. Burger King Corp., 82 P.3d 116, 122 (Ok. 2003) (not accounting for remote location and late hours). But see Kodiak Island Borough v. Roe, 63 P.3d 1009, 1015 (Alaska 2003) (noting, among other factors, that program for disabled women "knew that staff abuse of devclopmentally disabled residential clients was a risk").

206. A requirement of prior misconduct by a particular employee suggests that rape is committed by certain bad actors rather than opportunistic ones, which may not be an accurate picture of the assailants. See generally Katharine Baker, Once a Rapist? Motivational Evidence and Relevancy in Rape Law, 110 HARV. L. REv. 563 (1997).

207. See Kodiak Island Borough, 63 P.3d at 1011 (finding borough that operated facility for developmentally disabled women was negligent in hiring and giving room keys to an employee who had been convicted twenty-eight times of criminal offenses, including felony assault). 
to the employer. ${ }^{208}$ In the murkier circumstance in which there were prior problems with, but not necessarily sexual assaults by, the employee, cases also go both ways. In some cases, employer notice of prior problems with the employee make subsequent employer action (or more typically inaction) negligent. ${ }^{209}$ Yet in other cases, the employee's prior misconduct was not sufficient to raise a triable claim. ${ }^{210}$ Similarly, employee misconduct with one group of persons did not necessarily make foreseeable inappropriate sexual conduct toward others. ${ }^{211}$

Despite this narrow doctrine requiring prior bad acts in employer liability cases, courts allowed some claims of employer negligence when the assaulting employee had no apparent record of prior misconduct. For example, in N.X. v. Cabrini Medical Center, a surgical resident committed

208. See Reed v. Kelly, 37 S.W. 3d 274, 277 (Mo. Ct. App. 2000) ("In this case there is no nexus as a matter of law between Kelly's slapping his wife and his fistfights with a coemployee, both of which were angry physical altercations with persons he knew, and his commission of sexual assault on a stranger."); see also Hunter v. Dep't of Corr., 57 P.3d 755,759 (Idaho 2002) (holding that car wash could not foresee that employee who was on probation for "a sexual offense" and prohibited to interact with minors would rape and murder teenager who worked at the car wash); Bean v. Directions Unlimited, Inc., 609 N.W.2d 567, 570 n.5 (Mich. 2000) (holding that non-profit, which hired recovery center employee with past conviction of criminal sexual conduct involving a woman of limited mental abilities and gave him key to the center, was not liable for respondeat superior, negligent hiring or negligent supervision when employee engaged in sexual activity with woman of limited mental ability at the center because jury appropriately held that the employer's negligence was not the proximate cause of the plaintiff's injury).

209. In Saine v. Comcast Cablevision of Arkansa, Inc.s, 126 S.W.3d 339 (Ark. 2003), in a particularly grisly set of facts, a Comcast employee raped and attempted to murder a Comcast customer in her home. Id. at 340. The victim, who survived the atrocities, sued Comcast for vicarious liability and negligent hiring, supervision, and retention. Id. The plaintiff abandoned the vicarious liability claim, and the Arkansas Supreme Court ruled that she had failed to show a genuine issue of material fact on her remaining negligent hiring claim. $I d$. at 341-42. With respect to negligent supervision and retention, however, the court reversed the lower court's grant of summary judgment in favor of Comcast. Id. In response to its inquiry about whether Comcast knew or should have known that its employee posed a risk, the court found that a serious prior complaint against the employee had been reported. Id. at 43-44. Comcast had not followed up, however, or even kept a record of the complaint. Id. Comcast had no system for recording complaints. Id. In light of the prior complaint to nowhere, the plaintiff's claim on the negligent supervision and retention claims was allowed to proceed. Id.; see also Doe Parents No. 1 v. Dep't of Educ., 58 P.3d 545, 596 (Haw. 2003) (holding that prior indictment of school teacher for sexual misconduct should have prompted further school inquiry even though employee was found not guilty).

210. See Munroe v. Universal Health Servs., 596 S.E.2d 604 (Ga. 2004) (upholding summary judgment for employer who hired employee for mental health position involving personal contact with medicated, vulnerable patients despite third-party background check which suggested that employee had misrepresented reasons for firing, and could not account for much of his prior educational or employment experience).

211. See Keller v. Koca, 111 P.3d 445, 450-51 (Colo. 2005) (holding that employer's knowledge of employee's sexual misconduct toward female workers and customers did not make assault on child who accompanied another employee to work foreseeable); see also S. Baldwin Reg'l Medical Ctr. v. E.P., 785 So. 2d 368, 371 (Ala. 2000) (holding that while it was "debatable" whether hospital administrators exercised "sound judgment" in allowing a nurse with a history of emotional outbursts towards fellow employees and an elderly patient to work in direct contact with patients, the "particular criminal conduct" had to be foreseeable, and the nurse's molestation of a six-year-old child in the presence of her family was not foreseeable). 
sexual assault on a patient recovering from surgery. ${ }^{212}$ The New York Supreme Court allowed the victim to maintain an action for negligent supervision against the medical center despite a record of no prior misconduct by the resident, because sexual abuse of a patient in a post-surgical care situation may have been either observed or observable. ${ }^{213}$ Yet when sexual abuse was actually observed by an employee but committed by an independent-contractor security guard who the employee did not control and could not get immediate help to confront, a claim could not be stated against the employer. ${ }^{214}$ Given courts' unwillingness to expand negligence liability very far in the employment cases, it is surprising that claims of employer vicarious liability are excluded, ${ }^{215}$ and included, ${ }^{216}$ in a similar number of cases.

One question that must be addressed about foreseeability across these contexts is why a defendant, a hospital for example, should so broadly

212. 765 N.E.2d 844 (N.Y. 2002).

213. Id. at 848-49. Although the court noted that there is usually no liability for an employer if the employee had no prior record of misconduct (as was the case here), in this case the first occasion of abuse may have been either observed or observable, raising an issue about whether other employees knew or should have known about the assault as it was occurring. Id. at 848 . Hospital nurses were in close physical proximity to the resident and patient, and knew of a hospital policy not permitting gynecological examinations without a female nurse present. Id. at 848-49.

214. See Brown v. Argenbright Sec., Inc., 782 A.2d 752, 760 (D.C. 2001) (not permitting negligent supervision claim against store despite allegation that store employee was present at the time an independent security guard hired by the store sexually assaulted an alleged shoplifter because the employee did not have power to control the security guard or an opportunity to contact someone else).

215. See Kennedy v. W. Sizzlin Corp., 857 So. 2d 71 (Ala. 2003) (holding in a fractured opinion that franchisor was not liable for manager's sexual assaults on employees, except possibly on direct negligence claim); Regions Bank \& Trust v. Stone County Skilled Nursing Facility, 49 S.W.3d 107, 116 (Ark. 2001) (holding that assault by nursing aid on quadriplegic patient was a criminal act undertaken for the employee's own purposes); Piedmont Hosp., Inc. v. Palladino, 580 S.E.2d 215, 219 (Ga. 2003); Ocana v. Am. Furniture, 91 P.3d 58 (N.M. 2004) (finding no vicarious liability, negligent supervision or retention because employer had no prior notice of employee misbehavior); N.X., 765 N.E.2d at 847 (holding that sexual assault was committed with "wholly personal motives" and that this defeated finding of vicarious liability under New York case law).

216. See Brown v. Argenbright Sec., Inc., 782 A.2d 752, 758 (D.C. 2001) (rejecting "as too broad the statement in the trial court's order that 'sexual assaults are as a matter of law, solely for the employee's benefit" "and holding that respondeat superior claim should have gone to the jury to see if security guard's sexual assault of suspected shoplifter was "motivated to any extent by his desire to serve his employer"); Doe v. The Salvation Army, 835 So. 2d 76, 79 (Miss 2003) (finding camp liable for counselor's sexual assault on the basis that "a master who places a servant in a position of trust or authority is responsible for the actions of his servant"); Majorana v. Crown Cent. Petroleum Corp., 539 S.E.2d 426, 428-429 (Va. 2000) (holding that in light of evidence that the circumstances of gas station attendant's employment facilitated sexual assault on customer, court erred in granting summary judgment on respondeat superior claim); Doe v. Forrest, 853 A.2d 48, 67 (Vt. 2004) (rejecting several theories of vicarious liability but holding that "if the plaintiff can show that an on-duty law enforcement officer was aided in an intentional tort involving a sexual assault on the plaintiff by the existence of the employment relationship with the law enforcement agency, vicarious liability will apply"); see also Christopher E. Krueger, Mary M. v. City of Los Angeles: Should a City be Held Liable Under Respondeat Superior for a Rape By a Police Officer, 28 U.S.F. L. REv. 419, 460-61 (1994) (concluding that a city should be held liable under respondeat superior). 
foresee rapes on its property but not by its employees. ${ }^{217}$ Foreseeability tests might be made more consistent across categories or form a more minor part of the duty question. Tort law generally is evolving toward a general duty of reasonable care to prevent physical harms. ${ }^{218}$ The expansion of incidents considered similar under prior-similar-incidents tests in the recent premises liability cases and the loosening of employee priorbad-act standards in some employment cases may ultimately suggest a flaw in the prior-acts-based tests of foreseeability itself. Perhaps colleges should use reasonable care for students not just in reaction to reports of recent bad acts, but based on principles of special relationship and structural safety. In the shorter term, whether courts should adopt a broad view of similar incidents and ultimately foreseeability or a narrow one depends upon the fundamental policy question of the extent to which policymakers and the public want private parties to exercise reasonable precautions to protect against sexual assault like other physical safety risks. ${ }^{219}$

Outside the premises liability and employment contexts, the question of responsibility for rape prevention is no more certain. When considering whether to impose a duty of reasonable care that encompasses care to prevent sexual assault, courts have been willing to impose reasonable care requirements on a number of private actors but have been less sympathetic to imposing such obligations on public entities. Private actors, parents, foster parents, and others in parental-type situations have been held to have obligations of care to children. In Mary Anne " $Z Z$ " $v$. Blasen, for example, a parent who had promised to supervise her daughter's friend was found to have a duty to supervise that encompassed taking reasonable care to prevent rape. ${ }^{220}$ Similarly, in some states, foster parents can be sued for negligent supervision that allegedly led to a sexual assault between foster children, ${ }^{221}$ and placement agencies can be

217. See Diaz v. N.Y. Downtown Hosp., 784 N.E.2d 68, 69 (N.Y. 2002) (upholding hospital's motion for summary judgment on negligent supervision claim on the basis that plaintiff expert did not create a triable issue on industry standard when expert stated that recommended policy of two national organizations was to have woman in the room when male technician performed transvaginal sonogram "to ensure the personal safety of the female patient").

218. Restatement (Third) of Torts: Liability for Physical Harm (Basic PrinCIPLES) $\S 3$ (Tentative Draft No. 1 2001).

219. See generally Leslie Bender \& Perette Lawrence, Is the Tort Law Male?: Foreseeability Analysis and Property Managers' Liability for Third Party Rapes of Residents, 69 Chi.-Kent L. Rev. 313 (1993).

220. 284 A.D.2d 773, 774-75 (N.Y. App. Div. 2001) (holding that jury could decide reasonableness of mother's inattention to babysitting girls, when mother told friend's mother that she would keep an eye on the girls).

221. See Smith v. Four Corners Mental Health Ctr., Inc., 70 P.3d 904 (Utah 2003). In Smith, the Department of Human Services (DHS) and Four Corners Mental Health Center (Four Corners) placed two foster children with the Randalls. Id. at 907. One of the children, J.B., was alleged to have a violent character and homosexual tendencies. Id. at 908. When that child attacked the other, DHS and Four Corners were not liable. Id. at 914. However, the foster parents were not protected from suit by either governmental or parental immunity. Id. at 912,916. Governmental immunity was denied because the foster parents were not employees of DHS but rather independent contractors. Id. at 912 . 
sued for negligent placement of a child in foster care. ${ }^{222}$ An adult, who was not a parent but a boyfriend acting in loco parentis, had an obligation to control the child who committed the assault and protect the child who was assaulted under his watch. 223 Temporary guardians of children may also be sued.224 Other kinds of custodial care givers, such as nursing homes ${ }^{225}$ and psychiatric facilities, ${ }^{226}$ have been held to have such a duty that encompasses reasonable care to prevent sexual assault as well. In cases involving a more fleeting relationship without overtones of dependency, such as that between the church and a person who attends a church service, however, the relationship has not been held to create a duty to warn of prior sexual assaults, for instance by a priest. 227

In terms of public actors, whether state actors are immune from suit often turns on whether the public entity had purchased liability insurance coverage, ${ }^{228}$ was grossly negligent, ${ }^{229}$ or had a special duty to protect the

Moreover, parental immunity did not apply as it is not recognized in Utah and had been inadequately briefed. Id. at 916 . Although the foster parents also argued that they had no duty because the assault was not foreseeable, there was evidence that some violence was foreseeable as J.B. had beaten his own mother and threatened his siblings. Id. at 917.

222. See, e.g., Savage v. Utah, 104 P.3d 1242 (Utah 2004).

223. Gritzner v. Michael R., 611 N.W.2d 906, 924 (Wis. 2000) (but rejecting the claim that there was a duty to warn of ten-year-old's prior behavior).

224. See, e.g., Doe v. Evans, 814 So. 2 d 370 (Fla. 2002) (church may be sued despite First Amendment); Malicki v. Doe, 814 So. 2d 347 (Fla. 2002) (suit by parishioners against archdiocese for claims relate to sexual assaults by priest).

225. See, e.g., Regions Bank \& Trust v. Stone County Skilled Nursing Facility, 49 S.W.3d 107, 112 (Ark. 2001) (citing a Washington state case for the proposition that "[w]hile an employer generally does not have a duty to guard against the possibility that one of its employees may be an undiscovered sexual predator, a group home for developmentally disabled persons has a duty to protect residents from such predators regardless of whether those predators are strangers, visitors, other residents, or employees").

226. See, e.g., Bryson v. Banner Health Sys., 89 P.3d 800 (Alaska 2004) (holding that substance abuse treatment facility which knew of probationer's extensive criminal history of crimes of violence including sexual assault, placed probationer in support group in which members were encouraged to rely on each other, and failed to warn members that probationer might be dangerous had a duty to take reasonable care to protect patient from danger in the course of her treatment); Delk v. Columbia/HCA Healthcare Corp., 523 S.E.2d 826 (Va. 2000) (holding that psychiatric facility that was aware of victim's history of sexual abuse and assailant's "troubled history" and HIV status but took no action when he was in her room on an unauthorized basis, could be sued for negligence).

227. See Napieralski v. Unity Church of Greater Portland, 802 A.2d 391, 393 (Me. 2002); see also Glover v. Jackson State Univ., 755 So. 2d 395, 400 (Miss. 2000) (no duty of youth sports organization that funded program for disadvantaged children to supervise children).

228. See, e.g., Glover v. Jackson State Univ., 755 So. 2d 395, 400 (Miss. 2000) ("a governmental entity which has in effect a policy of liability insurance which covers the tort sued upon will waive immunity to the extent of the insurance coverage").

229. See Doe v. Baum, 72 S.W.3d 476, 486-82 (Ark. 2002) (holding that summary judgment was properly granted against girl who had been sexually assaulted by fellow student while on school bus, because state department of education had no responsibility to provide liability insurance and plaintiff had not established gross negligence by showing that bus driver was aware of earlier incident of sexual assault by student on the bus); Hunter v. Dep't of Corr., 57 P.3d 755, 759 (Idaho 2002) (estate of decedent who was raped and murdered by probationer could prove liability "by showing that the State acted with malice or criminal intent or that the State's action was reckless, willful and wanton" and that discretionary function immunity did not protect the state against liability for a reckless 
plaintiff ${ }^{230}$-a much more limited responsibility. Yet in some cases, a public entity was held to be grossly negligent, as when a teenager performing community service work for the city was left alone with an incarcerated prisoner who raped her. ${ }^{231}$ In other cases, the gross negligence issue was at least one for the jury, as when a school district did not provide a substitute school-bus attendant on a bus that included the mentally-impaired special-education-student plaintiff and the defendant, who had been declared a sexually aggressive child and had a protective plan which required that he not be left unsupervised with other children.232

In the absence of available insurance, gross negligence, or a special relationship with the plaintiff, courts have often held that the defendant is immune from suit ${ }^{233}$ or, alternatively, had no duty or breached no duty to the plaintiff. ${ }^{234}$ At times though, government actors may even be sued for negligence. ${ }^{235}$ And when a state permits liability of public employees, even if for gross negligence rather than negligence alone, using doctrines such as the public duty doctrine 236 "to shield all government employees from tort liability is at least arguably inconsistent with this statutory scheme." 237 Moreover, particular state statutes may, by their terms, pre-

operational decision, but that rape-murder was not foreseeable harm by the probationed rapist).

230. See, e.g., Doe v. State ex. rel. Miss. Dep't. of Corr., 859 So. 2d 35-, 359-60 (Miss. 2003) (state department of corrections enjoying immunity from suit brought by victim of rape committed by parolee); Wood v. Guilford County, 558 S.E.2d 490, 496 (N.C. 2002) (public duty doctrine preventing assault victim from suing county absent claim of special relationship, but not preventing her action against private security contractor). But see Yates v. Mansfield Bd. of Educ., 808 N.E.2d 861, 867-68 (Ohio 2004) (holding public-duty rule inapplicable on the basis that child sexual assault reporting statute was meant not only for the benefit of the specific child abused but for the protection of children in danger of abuse from the same source, in this case a school teacher).

231. See, e.g., Ashmore v. Hilton, 834 So. 2d 1131, 1139 (La. Ct. App. 2003) (funding city was grossly negligent for failing to supervise).

232. See ex rel. Doe v. Chicago Ortega-Piton Bd. of Educ., 820 N.E.2d 418, 420, 424 (III. 2004).

233. See also Doe v. Jenkins, 547 S.E.2d 124 (N.C. Ct. App. 2001) (holding that county had sovereign immunity that precluded suit brought by courthouse visitor for sexual assault by a stranger in the women's bathroom); Carter v. Glenn, 548 S.E.2d 110, 111 (Ga. Ct. App. 2001) (finding in suit based on rape by on-duty police officer, police chief and mayor were immune from suit); Ex Parte Blankenship v. Jackson, 806 So. 2d 1186, 1186, 1189 (Ala. 2001) (school principal and band director had discretionary immunity for allowing adult male who was not a student at the school to participate in the band and leave the school grounds with thirteen-year-old). But see District of Columbia v. Harris, 770 A.2d 82 (D.C. 2001).

234. See, e.g., Louviere v. Louviere, 839 So. 2d 57, 76 (La. Ct. App. 2002) (finding city police department not liable for negligent referral of problem officer who later went on a crime spree).

235. Doe Parents No. 1 v. Dep't of Educ. 58 P.3d 545, 579 (Haw. 2003) (holding that under state tort claims act state could be sued for negligent infliction of emotional distress as well as negligent retention and supervision of teacher).

236. Beaudrie v. Henderson, 631 N.W.2d 308, 313 (Mich. 2001) ("the public duty doctrine provides only that a plaintiff cannot rely on the fact that a public employee owes general duties to the public at large to support a claim of negligence").

237. Id. at 315-16 (holding that rape victim could sue police dispatcher who, because of friendship with assailant's mother, did not tell police the whereabouts of the assailant while the victim was being held captive). 
clude immunity. ${ }^{238}$ Public entities may have limited duties of care to protect against sexual assault in the constitutional tort context as well. ${ }^{239}$ However, this does not mean that they or their agents can initiate sexual assaults. ${ }^{240}$

The issues about scope of responsibility to use care for rape prevention are not confined to the doctrinal issue of duty. Proximate or legal cause issues are prominent in the recent cases addressing third-party responsibility for rape prevention. The question presented in these proximatecause cases is whether a duty to exercise care encompasses an obligation to take reasonable care to protect against rape and sexual assault. For example, is a casino's dram shop obligation not to serve a patron intoxicating liquors after she is drunk designed in part to protect her from rape? ${ }^{241}$ Are laws requiring mental health advisors to refer patients to licensed boarding homes designed to prevent patients from unsafe conditions including the possibility of sexual assault? ${ }^{242}$ Is it unreasonable to

238. Hubbard v. Canton City Sch. Bd. of Educ., 780 N.E.2d 543, 547 (Ohio 2002) (finding in a case in which students had been sexually assaulted by a teacher, board of education not immune from liability for damages based on court's reading of state immunity statute).

239. See Ashmore v. Hilton, 834 So. 2d 1131, 1140-41 (La. Ct. App. 2003) (although city had no policy for juveniles doing community service, finding no evidence of a need for a policy other than this sexual assault, such that plaintiff failed to prove a claim for 1983 liability).

240. See Alexander v. DeAngelo, 329 F.3d 912, 918-19 (7th Cir. 2003) (holding that officer's threats that woman would be jailed for forty years if she did not cooperate with sting operation that required her to pose as a prostitute and offer oral sex was rape, which constituted a serious battery and a violation of the Fourteenth Amendment, although qualified immunity applied to this new legal interpretation). In Virginia, a court with a number of extreme holdings, the court took an unusual approach to determining that a city was not liable for the intentionally wrongful acts of its police. In Niese v. City of Alexandria, 564 S.E.2d 127, 132 (Va. 2002), the court determined that a rape committed by a police officer during his investigation of the victim's complaint concerning her son was an immune governmental rather than proprietary function because the investigation of the victim's complaint "was tied to the health, safety, and welfare of the citizens."

241. See Horak v. Argosy Gaming Co., 648 N.W.2d 137, 148-50 (Iowa 2002) (raising potential proximate cause question in dram shop action against casino); $c f$. Westerback v. Harold LeClair Co., 735 N.E.2d 1256, 1258-60 (Mass. Ct. App. 2000) (holding that bar that served victim alcohol past the point of intoxication was not the proximate cause of her assault and rape while she was staggering home).

242. See Pathways, Inc. v. Hammons, 113 S.W.3d 85 (Ky. 2003). In Pathways, a private non-profit agency offered services for a mentally ill person. Consulting a very out of date list of boarding homes, a case worker recommended an unregistered boarding home operating in violation of court order. $I d$. at 87 . Patient went to the boarding home and was hit by another boarder. When she went to the hospital for treatment, the hospital tried to get the patient to stay elsewhere. However, the patient returned to the boarding house and was sexually assaulted by the other boarder. In a suit by the victim against Pathways and the boarding house, the court granted summary judgment for the nonprofit. Id. at 88 . The Kentucky Supreme Court found the no duty argument "repugnant" considering the vulnerability of counselees, and the fact that the unregistered boarding home created a risk to the patient's physical safety. Id. at 89 . The court also felt that it was a breach of duty for Pathways not to disseminate to its employees updates sent by the department of public health. Id. at 90-91. However, the court felt that the key issue was whether it was no longer Pathways' fault once the victim returned to the boarding house after having been assaulted once. Rather than count this a comparative fault argument to be weighed by the jury, the court held that the victim was on notice that the facility was unsafe and chose to return, such that the defendant was not the proximate cause of the sexual assault. Id. at 95 . A dissenter felt that the duty had been articulated too narrowly and that the defendant was 
hire an incompetent technician to go into people's homes, because the technician may not only perform the job poorly but may rape one of the homeowners? ${ }^{243}$ Is negligence that leads to a tire's failure in a remote area the proximate cause of a rape and murder there? ${ }^{244}$ In the vast majority of cases in which the proximate cause issue is raised by the court, that doctrine operates to defeat the plaintiff's liability claim against the defendant. $^{245}$

Although issues about the scope of the defendant's responsibility for care to prevent sexual assault are usually addressed under the doctrine of duty or proximate cause, actual cause can also be at issue. ${ }^{246}$ Actual cause issues are generally fact-based questions about whether a change in defendant's negligent conduct would have averted the harm. However, California courts indiscriminately refer to proximate cause (sometime called legal cause) and actual cause. ${ }^{247}$ Under this blended formula, California is apparently alone in the extent of its use of an aggressive actual cause doctrine to defeat sexual assault claims. ${ }^{248}$ Although the court's

the proximate cause given plaintiff's inability to make rational choices for herself. Id. at 94.

243. Saine v. Comcast Cablevision of Ark., 126 S.W.3d 339, 334-35 (Ark. 2003) (dismissing negligent hiring claim-as the harm that resulted was outside the scope of injury risked by the negligence-because the only thing that would likely have been discovered by an adequate background check was that the assailant employee was not a very good cable installer, not that he had perpetrated prior crimes, ); see, e.g., Regions Bank \& Trust v. Stone County Skilled Nursing Facility, 49 S.W.3d 107, 116 (Ark. 2001) (indicating that inexperience of nursing aid did not give rise to a reasonable probability that he would commit assault to establish negligent supervision claim).

244. See Stahlecker v. Ford Motor Co., 667 N.W.2d 244, 258-59 (Neb. 2003).

245. See, e.g., Louviere v. Louviere, 839 So. 2d 57, 76 (La. Ct. App. 2002) (holding that police department reference in favor of officer that did not mention officer's history of violence was not proximate cause of violence he committed in his later job at Sheriff's department, in part because department learned about that violence a few months before employee's crime spree and decided not to fire him). However, the dissent, which focused on foreseeability of the ultimate harm rather than of the intervening disclosure, explained "you can easily associate the duty not to recommend [the assailant officer] with his history of mental illness, being sexually abused, and his abusive treatment toward women, even while serving as a law enforcement officer, with the horrific acts he committed in this matter." Id. at 79 (Guidry, J., dissenting). But see Simpson v. Boyd, 880 So. 2d 1047, 1054 (Miss. 2004) (leaving proximate cause issue to jury in case alleging that obstructing emergency exits in violation of fire code was proximate cause of secretary's inability to escape from armed assailant in workplace).

246. See Lively v. Adventist Health Sys./Sunbelt, Inc., No. 2-02-418-CV, 2004 WL 1699913, at *4 (Tex. Ct. App. Jul. 29, 2004, no pet. h.) (barring nurse-victim's claim against hospital on the ground that "there is no security system that would prevent a woman who allows gang members to flag down her vehicle and then opens her door to them").

247. See Saelzler v. Advanced Group 400, 23 P.3d 1143, 1145, 1153 (Cal. 2001) (mixing actual cause, which is typically judged by a but-for or substantial-factor test, with proximate cause which is judged by a scope-of-risk test asking if the harm that occurred was the kind of harm to the category of persons that made the negligent act wrongful). California may not be alone in having difficulty applying actual and proximate cause tests. See State Farm Mut. Auto Ins. Co. v. Kastner, 77 P.3d 1256, 1266 (Col. 2003) (suggesting that a rape in a vehicle was not covered by car insurance because the car itself did not cause the assault).

248. See Saelzler, 23 P.3d at 1147 (granting summary judgment to owner of apartment complex that had received in one year 41 reports of trespass, 45 reports of broken perimeter fences and gates, criminal activities including gunshots, robberies, sexual assault and 
doctrine formally imposes restrictions based on specific proof of actual causation, it is clear that policy factors more typically addressed under the rubric of duty, negligence, or proximate cause underlie this mixed doctrine. ${ }^{249}$

Even when duties are recognized at common law, recently enacted tort reform statutes sometimes curtail third-party responsibilities. ${ }^{250}$ In a number of jurisdictions, victims filing third-party claims against health care providers must comply with the requirements of medical malpractice acts, at least against third-parties ${ }^{251}$ and sometimes assailants as well. ${ }^{252}$ Outside the medical malpractice context, plaintiffs may need to comply with other types of tort reform statutes as well. ${ }^{253}$

It is also unclear to whom defendants' responsibilities are owed. Current inquiries about the foreseeability of rape are an intensely gendered group. Court language about foreseeability is often focused on women or girls as particularly foreseeable prey. For instance, the Arkansas Supreme Court found it foreseeable that a cable company technician might harm a "female" customer. ${ }^{254}$ Similarly, the Maine Supreme Court wrote

rape, and evidence of a gang "headquartered" on the property, because the victim could not "prove" that defendants' failure to fix gates and hire daytime security guards was a "substantial factor in causing her injuries"). A dissent in Saelzler notes that California's present requirement essentially "imposes on plaintiff the burden of showing causation with certainty." Id. at 632 (Kennard, J., dissenting).

249. See id. at 627-629 (addressing burdensome financial costs of providing security, and expense of protecting a large open area which could only be protected by building "a Berlin wall."); id. at 641 (Kennedy, J., dissenting) (dissent addressing "the economic cost to tenants of allowing crime to flourish").

250. See generally Lucinda M. Finley, The Hidden Victims of Tort Reform: Women, Children, and the Elderly, 53 EMORY L.J. 1263 (2004).

251. For example, in Utah's Smith v. Four Corners Mental Health Center, Inc. case, the plaintiff who had been sexually assaulted by a co-foster child could not bring suit against Four Corners or his caseworker for negligent placement or supervision because he failed to comply with the Utah Health Care Medical Practice Act. 70 P.3d 904 (Utah 2003). The court held that the Act applied, because the defendant was a mental health care provider and the injury related to provision of mental health care services. Id. at 913 . Under the Act, the plaintiff was required to file his case within two years. Id. at 915-16. However, since the plaintiff was a minor at that time, his statute of limitations did not begin to run until age of majority. Id. Consequently, his action was timely filed. Id. However, at the time of filing, the plaintiff did not then request a pre-litigation panel under the Act. $I d$. at 915. As such, he could not maintain his action so no action against the defendant health care provider. Id. at 917-18.

252. See Mock v. Allen, 783 So. $2 \mathrm{~d} 828,833$ (Ala. 2000) (stating that "in cases where the alleged sexual misconduct occurs as part of a physician's examination and/or treatment of a patient, the conduct is considered to have occurred during the delivery of professional services, and is therefore cognizable as a medical-malpractice claim" for the purposes of tort reform). Many state courts that examine this question in the context of liability insurance coverage and vicarious liability have reached the opposite conclusion. Id. at 832-33.

253. See Kodiak Island Borough v. Roe, 63 P.3d 1009, 1011 (Alaska 2003) (applying non-economic damage caps liberally so that four assaults on victim were four separate claims under the damage cap rules, but holding that jurors should not have been instructed about existence of damage caps); Velez v. City of Jersey City, 850 A.2d 1238, 1246 (N.J. 2004) (holding that amendment to the state's Tort Claims Act extending the Act's notice of claim requirement to actions against public employees applied to claims for intentional torts, but applying that holding prospectively and not against the plaintiff).

254. Saine v. Comcast Cablevision of Ark., No. 02-1388, 2003 WL 22410813, at *4 (Ark. Oct. 23, 2003). 
that "the concentration of young people, especially young women, on a college campus, creates a favorable opportunity for criminal behavior." 255 And the Louisiana Supreme Court noted evidence that a "disproportionate number of victims of crimes at the mall were women."256 This language raises questions about whether boys or men harmed in the same situations would be considered foreseeable victims entitled to precaution, or whether courts are granting special tort protection to females that they would not afford to male victims. ${ }^{257}$

Overall, the responsibility of parties to anticipate sexual assault has broadened in a number of contexts in a fairly short time frame. The many doctrinal rules that have grown up around the issue of responsibility for rape prevention await more consistent and thoughtful development including whether the existence of prior assaults is a sensible touchstone on which to hinge responsibility for the use of reasonable care.

\section{B. Damages and Their Apportionment Between Multiple Actors.}

Damages in sexual assault cases have, at least in part, a significant dignitary dimension. Several of the recent cases raise questions about the appropriate measure of damages in sexual assault cases. As mentioned in section II of this article, even in some cases against assailants, juries or courts assigned liability for sexual assault but then awarded no damages. ${ }^{258}$ Inadequate damage awards may be a particular issue when the victim and the assailant are acquaintances or partners. ${ }^{259}$

255. Stanton v. Univ. of Me. Sys., 773 A.2d 1045, 1052 (Me. 2001).

256. L.A.C. v. Ward Parkway Shopping Ctr. Co., 75 S.W.3d 247, 254 (Mo. 2002).

257. See Regions Bank \& Trust v. Stone County Skilled Nursing Facility, 49 S.W.3d 107, 109 (Ark. 2001) (question of fact about whether nursing home was negligent in permitting unaccompanied access "to helpless female patients by make aides who had little or no previous health care experience"); Ashmore v. Hilton, 834 So. 2d 1131, 1138-39 (La. Ct. App. 2003) (quoting the trial court for the following proposition: "[i]rrespective of who is charged with the duty of supervising inmate[s], one can fathom that even the most careless man would be accustom[ed] to believing that inmates should not be left alone with a young girl").

258. See Bean v. Directions Unlimited, Inc., 609 N.W.2d 567, 572 n.10 (Mich. 2000) (noting jury holding that defendant touched the plaintiff without her consent but that plaintiff did not suffer damage); A.R.B. v. Elkin, 98 S.W.3d. 99, 103-04 (Mo. Ct. App. 2003) (finding by trial judge that father had committed sexual assault against children but awarding only nominal damages to the son and no damages to the daughter who, in the court's judgment, had not been physically harmed. On appeal, the court held that at a minimum, both plaintiffs should have been awarded nominal damages, but that further damages should have been considered as well); Kravitz v. Beech Hill Hosp., 808 A.2d 34, 43 (N.H. 2002) (court did not remand to the lower court for a redetermination of damages, but instead used the insignificant damages award to determine that the plaintiff had not been raped and to rule against the plaintiff on liability).

259. Louviere v. Louviere, 839 So. 2 d 57, 76 (La. Ct. App. 2002) (reviewing damages assessed for victims who were held hostage, three of whom were sexually assaulted, and assigning perpetrator's estranged wife less than $25 \%$ of damages awarded to an unrelated victim who was apparently subject to similar violations); A.R.B., 98 S.W.3d. at 104-05; Beaver v. Mont. Dep't of Natural Res. \& Conservation, 78 P.3d 857, 874-75 (Mont. 2003) (holding that $\$ 9,095$ award for sexual assault by co-worker was not inadequate). 
The adequacy of damages has been at issue in third party cases too, even when the victim was not only raped but murdered. In Brandon $v$. Richardson, a case stemming from the rape and murder of Brandon Teena, whose story was made into the Academy Award-winning movie Boys Don't Cry, the amount of compensatory damages awarded to the victim's family was extremely meager- $\$ 86,223$ for both economic and non-economic losses (and that only after two state supreme court decisions ruling favorably on a number of claims raised by the victim's family). ${ }^{260}$ Although the Nebraska Supreme Court ruled that an award of $\$ 0$ for the loss of the victim's comfort and companionship "bears no reasonable relationship to the evidence and shocks the conscience," 261 the court then affirmed the $\$ 5,000$ award subsequently provided by the trial court on remand. ${ }^{262}$

The reasoning the court employed to reach the conclusion that Brandon and her mother had a weak familial relationship belied a lack of education about the realities attendant to sexual assault. The Brandon court used testimony that Brandon had not revealed childhood sexual abuse by her uncle to her mother to undermine the mother's testimony that she had an open and trusting relationship with her daughter. ${ }^{263}$ However, if the court had been aware that child victims typically do not report sexual assault to others, ${ }^{264}$ perhaps the court's assessment of the strength of the underlying relationship would itself have been different. ${ }^{265}$

That several appellate cases present issues about the adequacy of damage awards is surprising given the procedural status of many appellatelevel sexual assault cases. State appellate-level courts often hear cases that were dismissed below on either a motion to dismiss or motion for summary judgment. Accordingly, many of the cases addressed by appellate courts do not involve damage awards at all.

To be sure, not every case affords such limited damages. ${ }^{266}$ In cases against third parties, a significant number of cases award compensatory

260. Brandon v. County of Richardson, 624 N.W.2d 604, 662 (Neb. 2001).

261. Id.

262. Brandon v. County of Richardson, 653 N.W.2d 829, 838 (Neb. 2002).

263. Id. at 836 .

264. See Kamala London \& Maggie Bruck, Disclosure of Child Sexual Abuse: What Does the Research Tell Us About the Ways that Children Tell?, 11 Psycol. PuB. PoL'Y \& L. 194, 195 (2005) (indicating that the majority of children do not reveal abuse during childhood).

265. This need for educating judges and juries about rape can be seen in a number of cases. For example, in Jackson v. Heard, 591 S.E.2d 487, 488-89 (Ga. Ct. App. 2003), the court permitted testimony that the victim was at the co-detendant's house "to provide sexual services for money," because that testimony if believed would "diminish the possibility" that she was given a "date rape drug" and "feared rape." However, showing that the victim was a prostitute might equally have been argued to make her more vulnerable to rape.

266. Univ. of S. Miss. v. Williams, 891 So. 2d 160, 176 (Miss. 2004) (noting jury award of $\$ 800,000$ to doctoral student sexually assaulted and harassed by doctoral committee, but remanding for new trial in part because damages awarded were too speculative). 
damages from $\$ 100,000$ to $\$ 200,000 .{ }^{267}$ However, at times verdicts for third-party damage awards have been quite substantial, exceeding $\$ 1$ million. ${ }^{268}$ In third-party cases, as elsewhere, punitive damages are only available in the case of wilful and malicious conduct. ${ }^{269}$

While the determination of an appropriate damage award can be difficult, apportioning those damages among multiple actors-the third party, assailant, and sexual assault victim-can be more difficult from a legal standpoint. A number of states have recently adopted legal changes-by statute or case law-that abolish joint and several liability and compare intentional and negligent torts in at least some contexts. ${ }^{270}$ Although these jurisdictions are still in the minority, ${ }^{271}$ in those states, juries assign shares of responsibility for the sexual assault to the various parties (and sometimes non-parties) potentially at fault. Each of the parties is assigned a percentage share of the total responsibility, with responsibility shares totaling one hundred percent. ${ }^{272}$ I have elsewhere criticized some of the problems and misunderstandings inherent in this type of comparative apportionment system, ${ }^{273}$ and recommended appropriate ameliorative doctrines. ${ }^{274}$ For the purposes of this paper, two problems seem

267. See United Fire \& Cas. Co. v. Shelly Funeral Home, Inc., 642 N.W.2d 648, 651 (Iowa 2002) (\$122,500 compensatory damages, $\$ 40,000$ punitive damages); Koenigstein $\mathbf{v}$. McKee, No. 2002-CA-092212-MR, 2004 WL 41738, at *2 (Ky. Ct. App. Jan. 9, 2004) (upholding jury verdict of $\$ 200,606$ for victim who was sexually assaulted by her uncle) (ordered not published, original on file with the author); Ashmore v. Hilton, 834 So. $2 \mathrm{~d} 1131$, 1134 (La. Ct. App. 2003) (\$153,365.64 for victim who was sexually assaulted by inmate while performing community service for the city); Bradley T. v. Cent. Catholic High Sch., 653 N.W.2d 813 (Neb. 2002) (damage amount of $\$ 125,000$ not excessive for student sexually assaulted at parochial school); Frazier v. Badger, 603 S.E.2d 587, 593 (S.C. 2004) ( $\$ 200,000$ compensatory damages, $\$ 200,000$ punitive damages).

268. Kodiak Island Borough v. Roe, 63 P.3d 1009, 1011 (Alaska 2003) (upholding a $\$ 1.35$ million jury verdict in favor of a developmentally disabled woman who became pregnant as a result of assault by an employee with twenty-eight prior criminal convictions who had been given a key to patient's room, based on ruling that four incidents of assault gave rise to four separate claims and damages were permissible for extraordinary costs of raising the child conceived during the assaults). Large damage verdicts appear more regularly in cases filed against the rapist directly.

269. Doe v. Salvation Army, 835 So. $2 d$ 76, 82 (Miss. 2003) (deciding that punitive damages issue would not be submitted to jury when no reasonable trier of fact could find malice or gross neglect/ reckless disregard).

270. See Bublick, The End Game, supra note 162, at 358.

271. Shin v. Sunriver Preparatory School, Inc., 111 P.3d 762, 776 (Or. Ct. App. 2005) (noting majority and minortiy rules and deciding not to apportion fault between negligent and intentional tortfeasors).

272. Kodiak Island Burough, 63 P.3d at 1015 (Alaska 2003) (rejecting apportionment between intentional and negligent tortfeasor defendants); Martin v. Prime Hospitality Corp., 785 A.2d 16, 21 (N.J. 2001); Louviere v. Louviere, 839 So. 2d 57, 77 (La. Ct. App. 2002) (holding that it was not error to let the jury decide whether the woman who had been raped and held hostage by her estranged husband at her place of employment "was negligent and whether her negligence was a cause of damages" and whether she should be assigned a percentage of responsibility for the harm that befell her).

273. See supra note 181 .

274. For example, the fault of non-parties may not be taken into account, Doe Parents No. 1 v. Dep't of Educ., 58 P.3d 545, 598 n.50 (Haw. 2003) (refusing to apportion fault between assailant and third-party on the ground that the assailant was not a party to the action), and the very duty rule may be adopted. Restatement (THIRD) TORTS: APPORTIONMENT OF LIBALITY $\$ 14$. 
worthy of particular note. ${ }^{275}$

First, comparative apportionment intensifies concerns about sexual assault victims being considered partially at fault for their own rapes. In jurisdictions that adopt comparative apportionment, a sexual assault victim may be assigned a share of the fault for the rape in a case involving both the rapist and a third party. ${ }^{276}$ The fault assignments in these cases may or may not have a large financial impact on sexual assault victims' actual recoveries (and could actually increase victims' recoveries if courts avoid defendant no-duty and no-proximate-cause rulings based on victim fault and instead allow the issues to go to a jury on comparative fault). ${ }^{277}$

However, I have elsewhere argued that courts should strike these victim-fault defenses. This is not because victims always behave reasonably. 278 Instead, limits may be justified in light of specific public policy interests, for example in some situations defendants may be better situated to attend to plaintiffs' interests than are the plaintiffs themselves. ${ }^{279}$ For example in the Pathways case, the plaintiff returned to an unlicensed mental health facility that had been recommended to her, even though she had previously suffered harm there. If the plaintiff wasn't competent to make choices for herself-one of the reasons she was initially referred to the institution-from a fairness and policy perspective, the law might not expect her to reasonably process her subsequent choices. ${ }^{280}$ More

275. Many additional issues arise in comparative apportionment systems. For example, the percentages of fault assigned to rapists and third-parties is often controversial. See, e.g., Hunter v. Dep't of Corr., 57 P.3d 755, 762 (Idaho 2002) (arguing that the jury verdict finding the employer had $20 \%$ of the fault for the murder and the murderer $40 \%$ "defies common sense" as the man "who actually killed [plaintiff] had virtually all, if not all the responsibility for her death").

276. See supra note 272.

277. Questions of plaintiff fault are sometimes implicit in arguments about the defendant's duty or the issue of proximate cause. For example, in Pathways, Inc. v. Hammons, 113 S.W.3d 85, 92-93 (Ky. 2003), the fact that the plaintiff went back to the institution after she had been assaulted there was not mentioned as plaintiff contributory fault but was factored into the lack of proximate cause. See also K.R. v. Sanford, 605 N.W.2d 387, 392 (Minn. 2000) (permitting victim to proceed with claim against the bar that employed her under Liquor Act's civil liability section on the ground that victim's purchase of alcohol for her attackers was complicity that would be for jury to weigh as comparative fault rather than absolute bar to recovery).

278. For example, the plaintiff in Horak was kicked out of the bar because on her intoxication and obnoxious behavior. Horak v. Argosy Gaming Co., 648 N.W.2d 137, 141 (Iowa 2002).

279. See Ellen Bublick, Comparative Fault to the Limits, 56 V AND. L. REV. 977 (2003) (arguing that comparative fault defenses may not be appropriate when, due to systemic differentials in knowledge, experience, or control, the defendant can be expected to take better care of the plaintiff's safety than can the plaintiff herself); see also Christensen v. Royal School Dist. No. 160, 124 P.3d 283, 288 (Wash. 2005).

280. Pathways, Inc., 113 S.W.3d at 94 (Stumbo, .I., dissenting) (showing the provider of psychiatric services who placed client in an unregistered boarding home "knew or should have known that the severity of the [victim's] mental disorder made it impossible for her to process choices, consequences, and develop alternative solutions for her housing and financial needs"). Moreover, going back to a familiar place, even if unsafe, may have been a rational choice. $I d$. at 93 (noting plaintiff testimony that she returned to the boarding house despite having been assaulted because "she had paid rent there through the month and was without money or means to go elsewhere). Similarly, in Smith, although the assaulted foster child may have shared a bedroom for eight months after the assault, the 
broadly, even when not subject to case-specific policy limits, assigning part of the blame for sexual assault to victims themselves may have significant negative effects in the aggregate on victim and potential victim, aka citizen, freedom, equality, and safety. ${ }^{281}$

Second, and perhaps more practically significant, in jurisdictions that abolish joint and several liability and adopt comparative apportionment, sexual assault victims may be left with diminished tort remedies. ${ }^{282}$ When juries assign percentages of liability to assailants, these percentages may not be recoverable from the assailants themselves but nevertheless diminish third parties' liability for damages. Much of this reduction rests not on judgments of fairness or policy about the wisdom of limiting victim recoveries, but on a logical fallacy made by courts in those jurisdictions. ${ }^{283}$ The fallacy is that comparative apportionment assigns responsibility based on the defendant's own fair share of the responsibility. As I have shown elsewhere, in truth the liability is not based on an assessment of the defendant's fault, but on an inverse relationship with the fault of others, which may or may not be justified. ${ }^{284}$ The concern with diminishing tort recoveries against third-parties is not simply a question of compensation for sexual assault victims, although that is an important component. It is also a concern about deterring defendants from creating, ignoring, or disguising foreseeable safety hazards. ${ }^{285}$ Accordingly, a

foster child may not have had any reasonable alternate options. Smith v. Four Corners Mental Health Ctr., Inc., 70 P.3d 904, 908 n.3 (Utah 2003); see also Christensen v. Royal Sch. Dist. No. 160, No. 75214-1, 2005 WL 3346205 (Wash. Dec. 8, 2005) (holding that children do not have a duty to protect themselves from sexual abuse).

281. See Bublick, Citizen No-Duty Rules, supra note 190, at 1420-24.

282. See Louviere v. Louviere, 839 So. 2 d 57, 76 (La. Ct. App. 2002) (reassigning responsibility percentages on appeal so that $85 \%$ of fault was assigned to jailed intentional tortfeasor and $15 \%$ fell to sheriff's department); see also Brandon v. County of Richardson, 624 N.W.2d 604, 618 (Neb. 2001) (analyzing case in which estate of victim of rape and murder awarded $\$ 80,000$ in noneconomic damages, and $85 \%$ of the responsibility for the plaintiff's award was assigned to the imprisoned murderers). On appeal the Nebraska Supreme Court refused to permit the Sheriff's Department to compare its negligence with the murderer's homicide. Had the court not done so, the victim's estate would have been able to recover only $\$ 18,000$ for the Sheriff's Department's adjudicated and legally recognized negligence which led to the death). Id. at 620 . Because of intentional-negligent fault comparisons in a several liability system, a woman who had been sexually assaulted by a doctor she was required to see despite her insurance company's knowledge of previous accusations of sexual assault against the doctor, the assault victim received $60 \%$ less of her compensatory damage award-reducing her compensatory damages award against the insurer from $\$ 46,000$ to $\$ 16,000$. See Slack v. Farmers Ins. Exchange, 5 P.3d 280, 287-88 (Col. 2000); see also Wallmuth v. Rapides Parish School Board, 813 So. 2d 341, 345, 349 (La. 2002) (evaluating trial court's assignment of $100 \%$ of fault to school board and $0 \%$ to intentional tortfeasor, appellate court finding that school board was $70 \%$ at fault and intentional tortfeasor $30 \%$ at fault, and reversing the judgment against the school board entirely).

283. See generally Bublick, The End Game, supra note 162.

284. Id. at 407-08 (providing an example of a gunshot wound made by injuring parties with different degrees of fault treated in the same way by a negligent doctor).

285. For example, after a door-to-door vacuum cleaner sales company was held liable for damages in a case in which an employee with a prior history of sexual assault convictions raped a customer in her home, the company instituted the employee background checks that it had previously maintained it was unable to institute. Read v. Scott Fetzer Co., 990 S.W.2d 732, 736 n.1 (Tex. 1998). Similarly, liability may persuade companies to 
number of victims' groups have opposed comparative apportionment rules that include intentional torts. ${ }^{286}$

\section{Availability of Compensation}

If a judgment is awarded, the availability of insurance, indemnification, and workers compensation to meet the monetary claims of sexual assault victims becomes important. A number of current cases address insurance coverage for sexual assault claims. The policies from which coverage has been sought include homeowner's policies, ${ }^{287}$ commercial general liability policies, ${ }^{288}$ professional liability policies, ${ }^{289}$ self-insurance funds, ${ }^{290}$ and others. ${ }^{291}$ The question in these cases is generally not whether a victim can seek coverage from an insured who commits an intentional tort such as battery. That coverage has been consistently barred.292 Instead, the questions more typically concern whether insurance policies cover claims of negligence lodged against the assailants themselves ${ }^{293}$ or against third-

introduce inexpensive security measures that can produce "outstanding" results. For instance, Wal-Mart found that inexpensive parking lot security could substantially reduce $80 \%$ of its crimes that occurred in the parking lot or outside perimeter of its stores. McClung v. Delta Square L.P., 937 S.W.2d 891, 904 n.13 (Tenn. 1996). In addition, questions of accountability are critical. For example, in one case a motel in a high crime area had provided alarms to protect its television sets though not its guests. Wassell v. Adams, 865 F.2d 849, 851 (7th Cir. 1989).

286. Given the effects of comparative apportionment and several liability on sexual assault victims' ability to recover compensation from negligent defendants, advocates for sexual assault victims have opposed legislation advocating "comparative responsibility." When the Connecticut Supreme Court decided to compare intentional and negligent fault, groups including the Connecticut Sexual Assault Crisis Services and the Legal Assistance Resource Center of Connecticut (a low-income advocacy organization) successfully appealed to that state's legislature to overturn the court's decision. Thomas Scheffey, Lawmakers Unmake Bhinder, The Conn. L. Trib., May 10, 1999. Similarly, when Pennsylvania considered a comparative apportionment law, victims rights groups like Mothers Against Drunk Driving spoke out against it, and only a comparative fault bill was passed.

287. See, e.g., Korhonen v. Allstate Ins. Co., 827 A.2d 833, 834 (Me. 2003); Am. Commerce Ins. Co. v. Porto, 811 A.2d 1185, 1189 (R.I. 2002).

288. See, e.g., United Fire \& Cas. Co. v. Shelly Funeral Home, Inc., 642 N.W.2d 648, 651 (Iowa 2002); Minnis v. Or. Mut. Ins. Co., 48 P.3d 137, 148 (Or. 2002).

289. See, e.g., R.W. v. Schrein, 642 N.W.2d 505, 508 (Neb. 2002); Ross v. Home Ins. Co., 773 A.2d 654, 656 (N.H. 2001); T.M. v. Executive Risk Indem. Inc., 59 P.3d 721, 723 (Wyo. 2003).

290. See, e.g., Wolfe v. Anne Arundel County, 821 A.2d 52, 62 (Md. 2003) (holding that $\$ 1.15$ million compensatory and punitive damage award against police officer who raped motorist could not be collected from county self insurance funds).

291. See, e.g., Bd. of Educ. of Bridgeport v. St. Paul Fire \& Marine Ins. Co., 801 A.2d 752,754 (Conn. 2002).

292. See United Fire \& Cas. Co., 642 N.W.2d at 652 ("The district court found and there is no dispute on appeal, that the jury's verdicts against [the assailant] for intentional infliction of emotional distress and indecent exposure were 'clearly based on intentional conduct and not an 'occurrence' as defined in the policy" "); $c f$. Vibert v. Bd. of Educ. of Reg'l Sch. Dist. No. 10, 793 A.2d 1076, 1078-79 (Conn. 2002) (holding that school did not have to defend teacher against sexual assault action brought by former student). At times, insurance policies may disclaim only "intentional acts by the insured," in which case an intentional tort caused by the insured's child may be covered, as it was in Morris. Morris v. Yogi Bear's Jellystone Park Camp Resort, 539 So. 2d 70, 72 (La. Ct. App. 1989).

293. See St. Paul Fire \& Marine Ins. Co. v. Engelmann, 639 N.W.2d 192, 198 (S.D. 2002). 
parties. ${ }^{294}$

The cases law here reveals the confusion and disarray that sustains repeated litigation. When a victim seeks insurance coverage from the assailant based on claims of negligence, recovery is uncertain. In professional liability policies, for example, the question is often whether the plaintiff suffered damages resulting from "the providing or withholding of professional services." Professional services are frequently defined as those services that require training and skill. ${ }^{295}$ Some courts ask whether the assault itself is a professional service, in which case coverage is almost certainly unavailable. ${ }^{296}$ As courts hasten to note, sexual assault is a type of misconduct for which no training is required. ${ }^{297}$ However, other jurisdictions ask instead whether the sexual assault was intertwined with the professional services. ${ }^{298}$ Although this distinction could make a difference in cases that involve sexual assault that occurs during the provision of professional services--for example an assault by a doctor on a patient during a physical exam or by a lawyer on a client during a legal counseling session ${ }^{299}$-it does not necessarily do so. ${ }^{300}$ Even when the victim pleads the assailant's professional negligence not an intentional tort, and when the sexual assault takes place in the office in the course of the professional relationship, some courts applying this test have precluded coverage. ${ }^{301}$

And yet, coverage is not uniformly precluded. If the victim can make an allegation that the jury's negligence verdict was based on either the sexual assault or other professional misconduct, insurance coverage may be accessible. For example, in the case of a gynecologist who was accused of raping plaintiffs during gynecological exams, the insurer provided the defendant doctor with "a splendid defense" in a case that presented two theories of negligence to the jury-improper sexual contact, and using "improper positions, procedures and methods in conducting those examinations." 302 In its fealty to the insured, the insurer did not advocate for special interrogatories or special verdicts on the allegations. ${ }^{303}$ Because a general verdict was entered "subject to two different constructions," one

294. See Am. Commerce Ins. Co. v. Porto, 811 A.2d 1185, 1189 (R.I. 2002).

295. See St. Paul Fire \& Marine Ins. Co., 639 N.W.2d at 197.

296. See Ross v. Home Ins. Co., 773 A.2d 654, 657 (N.H. 2001); St. Paul Fire \& Marine Ins. Co., 639 N.W.2d at 198.

297. See R.W. v. Schrein, 642 N.W.2d 505, 513 (Neb. 2002); St. Paul Fire \& Marine Ins. Co., 639 N.W.2d at 198.

298. See Ross, 773 A.2d at 657.

299. See, e.g., St. Paul Fire \& Marine Ins. Co., 639 N.W.2d at 197-70 (saying it is not a jurisdiction that covers the physician rather than the services, but then allowing the coverage question in the circumstances of that case).

300. See Schrein, 642 N.W.2d at 515; Ross, 773 A.2d at $657-58$ (citing intertwined standard but then denying coverage for claim that arose in professional's professional setting).

301. In several insurance cases, courts have held that professional liability policies do not cover liability for sexual assault by professionals like lawyers or doctors even if the assaults take place in the office and during the course of the professional's practice. See, e.g., Schrein, 642 N.W.2d at 515 (no public policy requiring payment); Ross, 773 A.2d 654 .

302. St. Paul Fire \& Marine Ins. Co., 639 N.W.2d at 198.

303. Id. 
of which "was sustainable for coverage purposes," it was arguable that the judgment fell within the scope of the insurance coverage. ${ }^{304}$

Perhaps the difference between this outcome and the outcome of other cases in which the professional's malpractice was also asserted is simply that there was a stronger tag along case of medical negligence not based on the sexual assault itself. ${ }^{305}$ But that potential point of reconciliation seems far from certain. ${ }^{306}$ As one state supreme court justice noted, careful pleading is particularly important in cases involving sexual misconduct. ${ }^{307}$

If coverage in cases in which the assailant was alleged to have been negligent is uncertain, the availability of coverage when a third party was alleged to have been negligent is even more contested. ${ }^{308}$ In some cases, courts have held that insurance covers third-party negligence claims against the insured. For example in United Fire \& Casualty Co. v. Shelly Funeral Home, Inc., the Iowa Supreme Court held that under a commercial general liability policy a negligent supervision claim was covered because the sexual assault was not bodily injury "expected or intended from the standpoint of the insured" company. ${ }^{309}$ From the standpoint of the insured (unlike the standpoint of its employee), the assault was an accident. Because the negligence was considered an accident rather than an intended injury, the CGL policy could cover the victim's claim. ${ }^{310}$ The New York Supreme Court reached a similar holding that sexual assault by the insured's employee qualified as an "accident" with respect to the insured. 311 The word "occurrence" in an insurance contract has been inter-

304. Id.

305. Montgomery County Bd. of Educ. v. Horace Mann Ins., 860 A.2d 909, 920 (Md. 2004) (holding that teacher's liability insurer had a duty to defend teacher in student's lawsuit alleging sexual abuse because "there was more alleged and discovered ... than simply the sexual abuse," including an inappropriate relationship with gifts and love notes).

306. Schrein, 642 N.W.2d at 509 (alleging that doctor unnecessarily inserted a tube into the plaintiff's penis along with other claims of sexual assault); Ross, 773 A.2d at 656 (alleging breach of fiduciary duty by lawyer who asked client to come to the office to sign documents and raped her, though it is not clear whether the breach claim was entirely focused on the sexual assault itself or also the failure to explain or recommend appropriate documents for example).

307. W. Va. Fire \& Cas. Co. v. Stanley, 602 S.E.2d 483, 492 (W. Va. 2004) (Starcher, J., concurring) ("[t]he obvious rule for plaintiff's lawyers to take away from this case is to carefully plead any case involving sexual misconduct or other intentional tort").

308. Compare Bd. of Educ. of Bridgeport v. St. Paul Fire \& Marine Ins. Co., 801 A.2d 752,757 (Conn. 2002) (showing liability insurance policy that covered injuries from "use" of the school bus, included coverage for sexual assault when special education student was sexually assaulted after getting off of the bus without supervision), with State Farm Mut. Auto Ins. Co. v. Kastner, 77 P.3d 1256, 1265 (Colo. 2003) (holding that automobile insurance did not cover sexual assault that took place in plaintiff's automobile because the term "use" of a vehicle did not include non-transportation usc).

309. 642 N.W.2d 648, 655 (Iowa 2002).

310. See also C.P. ex rel. M.L. v. Allstate Ins. Co., 996 P.2d 1216, 1223-24 (Alaska 2000) (deciding that sexual assault was accident from the standpoint of insured parents even though it was intended by insured adult son who committed the assault such that coverage should not have been excluded).

311. RJC Realty Holding Corp. v. Republic Franklin Ins. Co., 808 N.E.2d 1263, 1266 (N.Y. 2004); see also Roman Catholic Diocese of Dallas v. Interstate Fire \& Cas. Co., 133 S.W.3d 887, 894 (Texas 2004) (holding that whether priest sexual abuse was an accident 
preted to provide even broader coverage. ${ }^{312}$ In a similar vein, a homeowner's policy, while not covering the homeowner father's intentional sexual assault, was nevertheless found potentially applicable to cover the mother's negligent supervision of the child, where that negligence alleged was arguably separate from the assault itself. ${ }^{313}$ And when a psychologist failed to inform state family services that her husband had been accused of abusing children, her professional liability policy might cover claims of negligence against her when her husband abused the foster children she took in her home on a temporary basis. ${ }^{314}$ The issue was whether she was providing psychological services to the abused children such that the professional liability insurance might apply. ${ }^{315}$

At times, coverage depends on the inferred-intent rule, a rule under which courts presume intent to harm as a matter of law based on the nature and character of the insured's acts, regardless of the insured's asserted subjective intent. ${ }^{316}$ Often the inferred intent rule has been applied to bar coverage in sexual assault cases. ${ }^{317}$ However, that rule may not apply in cases where a minor committed the assaults, because minors' relative lack of experience in sexual matters makes it imporper to infer an intent to injure. ${ }^{318}$

In contrast to the large number of cases affording coverage for thirdparty-negligence claims, in a number of similar cases, allegations of thirdparty negligence were not covered by other CGL or homeowners insurance policies. ${ }^{319}$ At times, the insurance contracts did not cover "bodily injury" at all (whether or not expected or intended), ${ }^{320}$ or the intentional misconduct source of the plaintiff's injury was enough to bar coverage, even if the insured itself had not committed any intentional tort and was alleged to have been a negligent third party. ${ }^{321} \mathrm{~A}$ number of contracts

was to be measured from the standpoint of the insured diocese and fact issues concerning the knowledge of the diocese precluded summary judgment for the insurer).

312. See N. Sec. Ins. Co. v. Perron, 777 A.2d 151, 157 (Vt. 2001) (holding in declaratory judgment on homeowner's liability insurance that sexual assault by son of children in home day-care was occurrence).

313. Korhonene v. Allstate Ins. Co., 827 A.2d 833. 837-39 (Me. 2003) (noting that the negligent supervision alleged was not for the assault itself, but for the child's access to alcohol, the mother's failure to learn of the assault, and the mother's assignment of blame to the child).

314. See T.M. v. Executive Risk Indem. Inc., 59 P.3d 721, 724 (Wyo. 2003). Of course, a number of these cases depend on specific policy language, as in this case. But the policy language itself does not seem to provide a predictable guide to outcomes.

315. Id. at 727 .

316. See N. Sec. Ins. Co. v. Perron, 777 A.2d 151, 158 (Vt. 2001).

317. See id.

318. See id. at 159.

319. See Ross v. Home Ins. Co., 773 A.2d 654, 658 (N.H. 2001). In some cases, courts have found that the employer is not covered under a CGL policy for assaults by its employees at work or outside of work. See Minnis v. Or. Mut. Ins. Co., 48 P.3d 137, 138 (Or. 2002).

320. See M.C. v. N. Ins. Co. of N.Y., 1 P.3d 673, 676 (Alaska 2000).

321. See W. Va. Fire \& Cas. Co. v. Stanley, 602 S.E.2d 483, 492 (W. Va. 2004) (sexual assaults on six-year-old by uncle and concealment of assaults by child's grandparents were deliberate acts that did not constitute an accident); Am. Commerce Ins. Co. v. Porto, 811 A.2d 1185, 1201-02 (R.I. 2002); Kim v. Nat'l Indem. Co., 6 P.3d 264, 270 (Alaska 2000) 
contained explicit sexual assault exclusions, which were sometimes read broadly by the courts. ${ }^{322}$ This was the case in the recent Rhode Island Supreme Court case American Commerce Ins. Co. v. Porto. ${ }^{323}$ In Porto, a boy scout was sexually molested by his troop leader. The boy and his parents brought suit against the boy scouts as well as the leader's supervisor. Against the supervisor, the boy scout claimed negligent hiring, negligent supervision, and negligent failure to educate the boys about how to respond to sexual assault. ${ }^{324}$ Although the claim against the supervisor was for negligence and could not have been for anything more, the Rhode Island Supreme Court ruled that the defendant's homeowner's insurance did not cover the negligence claims against him. ${ }^{325}$ In reaching its conclusion, rather than adopt a narrow view of the exclusion, ${ }^{326}$ the court adopted a broad interpretation of the policy exclusion for claims "arising out of actual or threatened sexual molestation."327 Rather than confine the clause to a denial of coverage to the perpetrator of a sexual assault, the court extended the exclusion to any claims that had a causal connection with actual, alleged, or threatened sexual molestation. ${ }^{328}$ The court adopted an equally expansive view of what constituted "threatened sexual molestation." The court defined this term to include not only unwanted sexual contact, but also "verbal advances or displaying sexually

(holding that commercial automobile insurance did not cover taxicab driver's sexual assault of minor passenger because damages were not result of "accident" and injuries were "expected or intended from the standpoint of the insured"), overruled by Shaw v. State Farm Mut. Auto. Ins. Co., 19 P.3d 588, 591, 590 (Alaska 2001) (noting that the appellant in Kim did not argue that "the abuse could have been an 'accident' from the minor's perspective even though it was not an 'accident' from the tortfeasor's perspective"). Of course ordinarily the injury is also expected from the standpoint of the assailant. St. Paul Fire \& Marine Ins. Co. v. Engelmann, 639 N.W.2d 192, 195-96 (S.D. 2002).

322. See, e.g., Cmty. Action for Greater Middlesex County, Inc. v. Am. Alliance Ins. Co., 757 A.2d 1074, 1081-82 (Conn. 2000).

323. 811 A.2d 1185 (R.I. 2002).

324. Id. at 1189 .

325. Id. at 1202 .

326. See RJC Realty Holding Corp. v. Republic Franklin Ins. Co., 808 N.E.2d 1263 (N.Y. 2004) (holding that clause that excluded insurance for claims "arising out of" a body massage only included injuries like bruises from a massage rather than a sexual assault as well).

327. Am. Commerce Ins. Co., 811 A.2d at 1197.

328. Id. at 1195. Perhaps more disconcerting than the lack of a public policy analysis in the Rhode Island court's reasoning, was the court's evident confusion on the issue of causation. For example, the court stated that "[p]roximate cause [in tort cases] is established by showing that but for the negligence of the tortfeasor, injury to the plaintiff would not have occurred." Id. However, the but-for test is the test of actual, not proximate cause. Thus when the court wrote, in its conclusion that "[b]ut for the allegations injuries to [the plaintiff] arising from [the Boy Scout leader's] sexual assault, [the co-leader's] alleged negligence would not have caused [the plaintiff] any bodily injury damages whatsoever and the family would have no claims for loss of consortium," id. at 1202, one wonders, so what? No one alleged that the defendant was the sole cause of the plaintiff's injuries. Actual cause analysis, and even proximate cause analysis, can accommodate injuries that stem from more than one act of negligent or intentional misconduct. If the homeowner had negligently supervised his child, who then intentionally put ice on the floor on which the plaintiff slipped, it would be remarkable if the court precluded insurance coverage to the homeowner on the ground that there would have been no claim against the homeowner absent the intentional tort. 
explicit images or suggestive pictures to the victim" since they may "sometimes lead to" an actual sexual assault upon the victim. ${ }^{329}$ With those all-encompassing interpretations of the exclusion, even plaintiff's claim that he was shown pornography was considered part of the actual or threatened molestation for insurance purposes. 330

At issue in the case law quite centrally is the availability of insurance coverage and some consistency in determinations and policy goals. The Rhode Island court outlined plaintiff's public policy arguments as well as those raised by the defendant. However, the court did not directly address any of the arguments. Instead, the court wrote that the exclusion did not violate public policy because the exclusion was written into the contract language-an expansive right-to-contract analysis which would seem to preclude any discussion of public policy concerns. ${ }^{331}$

Even in the context of workers compensation coverage, coverage questions have not followed uniform patterns or turned on simple at-work/offwork distinctions. When the sexual assault took place in the course of employment and during work hours, workers compensation may or may not furnish the sexual assault victim's exclusive source of compensation. ${ }^{332}$

Ultimately, while insurance litigation will always depend on the particular language of the policy at issue and the particular circumstances of the case at issue, policy language did not appear to play a pivotal role in coverage determinations. Instead, when the insured has committed sexual assault, coverage may depend on the plaintiff's attorney's artful defense-particularly simultaneous proof of the insured's additional negligence-and the luck of the draw with respect to coverage of third-party claims of negligence. The question still contested in state courts is whether exclusions for intentional torts bar coverage even when those torts are negligent with respect to the insured. More attention should also be paid to questions about whether public policy supports or rejects coverage of negligence claims against assailants and third parties. ${ }^{333}$

329. Id. at 1199 .

330. Id.

331. Id. at 1201.

332. See Horodyskyj v. Karanian, 32 P.3d 470, 480 (Colo. 2001) (en banc) (not covering sexual harassment and assault in the course of employment under worker's compensation); Driscoll v. Gen. Nutrition Corp., 752 A.2d 1069, 1076 (Conn. 2000) (holding that workers' compensation, even if little or none was available for sexual assault, provided employee's exclusive compensation); Rogers v. Burger King Corp., 82 P.3d 116, 121 (Okla. 2003) (workers' compensation act provided exclusive remedy for worker abducted from work at gunpoint and sexually assaulted). Of course, workers' compensation acts do not bar employee claims against third parties. See Wood v. Guilford County, 558 S.E.2d 490, 494 (N.C. 2002). See generally Jane Korn, The Fungible Woman and Other Myths of Sexual Harassment, 67 TUL . L. REv. 1363, 1417 (1993) (arguing that workers' compensation should not be the exclusive remedy for sexual harassment). Workers' compensation does not preclude an employee's contract claims. Shattuck-Owen v. Snowbird Corp., 16 P.3d 555, 561 (Utah 2000).

333. See R.W. v. Schrein, 642 N.W.2d 505, 516 (Neb. 2002) (noting that the state requires proof of insurance coverage in order to practice in the state, and suggesting a need 


\section{Privacy and Confidentiality of Victims}

A final set of issues worthy of special note in the current tort litigation concerns sexual assault victims' privacy interests. ${ }^{334}$ These privacy concerns include both the protection of victim privacy and confidentiality within civil litigation, and the vindication of victim privacy interests through tort privacy actions.

In the first context, issues surrounding victim privacy are at issue even before a sexual assault victim pursues a legal action. In a number of current cases, evidence gatherers who may subsequently be sued as tort defendants can have real conflicts of interests with sexual assault victims. For example, in Kravitz $v$. Beech Hospital, ${ }^{335}$ the doctor at the drug and alcohol treatment facility at which the plaintiff was allegedly raped, gathered evidence from the plaintiff about her rape even though that doctor was also an employee of the facility that later became a defendant in the case. ${ }^{336}$ Similarly in Shattuck-Owen $v$. Snowbird Corp, ${ }^{337}$ a woman who was sexually assaulted in her workplace was required to speak with the employee assistance program personnel rather than an outside counselor. ${ }^{338}$ In these situations, the person gathering evidence from the victim about her sexual assault has a conflict of interest with the victim herself. On the one hand the victim may view the doctor or counselor as her fiduciary, and on the other hand that person, as an employee of the defendant, may not be acting in that capacity. This situation raises concerns about objectivity and informed consent. If victims are not attended by independent evidence-gatherers after the rape, legal doctrines could be set in place that would require the defendant's employees to give victims information about potential conflicts of interest as well as their available neutral alternatives. Such warnings might be required at the defendant's peril if they are not issued.

Once within the legal process, issues about discovery of private information are important in civil as well as criminal cases. From the very beginning of tort litigation, privacy issues can arise. One issue is whether the plaintiff can proceed pseudonomously. While these proceedings are common in sexual assault cases, ${ }^{339}$ at least one court was hostile to such proceedings in light of the plaintiff's initiation of the case. ${ }^{340}$ Evidentiary

for compensation for people harmed but also expressing concern about insurance as a potential shield to professionals from the consequences of their actions).

334. See Susan Vickers, The Second Wave: An Agenda for the Next Thirty Years of Rape Law Reform, 38 SufFolK U. L. Rev. 467, 473 (2005) (asserting that for most sexual assault victims, "privacy is like oxygen," a constant need).

335. 808 A.2d 34 (N.H. 2002).

336. Id. at 40 .

337. 16 P.3d 555 (Utah 2000).

338. Id. at 559 n.2 (demand that victim see in-house employee assistance personnel was not a violation of the victim's privacy).

339. See, e.g., Doe Parents No. 1 v. Dep't of Educ., 58 P.3d 545, 552 n.2 (Haw. 2003); L.C.H. v. T.S., 28 P.3d 915, 917 n.1 (Alaska 2001).

340. See Doe v. Briscoe, No. CL02-499, 2003 WL 22748373 (Va. Ct. App. Apr. 24, 2003). 
concerns, particularly with respect to the victim's prior sexual contact may also be at issue. Evidence about a victim's history of prior sexual contacts or abuse often arises in litigation. For example, although the Kravitz court said that it would bar evidence about the victim's prior sexual contacts, a witness nevertheless testified about those contacts and the court held that the victim's case had not been prejudiced by the testimony. ${ }^{341}$ Discussion of the victim's past sexual contacts and history of prior sexual abuse often appear in even appellate court opinions. ${ }^{342}$ However, some courts have been deliberately sensitive to privacy concerns when writing opinions, omitting details of the assaults not necessary to discussion of the legal issues and likely to further embarrass the victim throughout the civil litigation. ${ }^{343}$ Evidence regarding of prior sexual contacts may be at issue for assailants as well as plaintiffs. ${ }^{344}$ In the thirdparty context, where prior incidents are considered a factor in foreseeability, the relevant question may be admissibility of prior similar incidents, which can be prejudicial against the landowner but also necessary to the issue of foreseeability or notice. 345

Sexual assault victims can affirmatively seek vindication of their privacy interests through the tort law. The two most likely privacy torts under which a victim can bring suit are the tort of intrusion on seclusion, and the tort of publication of private facts. To prove the first tort, the plaintiff must show that there is an intentional intrusion on a matter of private concern, which would be considered highly offensive to a reasonable person. ${ }^{346}$ To prove the second form of privacy invasion, the plaintiff must show that the defendant publicly disclosed a private fact about the plaintiff, which would be highly offensive to a reasonable person and is not a matter of legitimate public concern. ${ }^{347} \mathrm{~A}$ recent state supreme court case that examines the privacy causes of action in a sexual-assault case is Shattuck-Owen $v$. Snowbird Corp. ${ }^{348}$ In that case the plaintiff, a server in a banquet department, was sexually assaulted in the lounge area of her workplace while she was on a break. ${ }^{349}$ The assault was recorded by security cameras. The employer displayed the full videotape of the employee's sexual assault to at least twelve individuals. ${ }^{350}$ Although it is unclear exactly who saw the tape, the plaintiff alleged that several of these people had no legitimate interest in viewing the tape. ${ }^{351}$ In re-

341. 808 A.2d 34 at 40.

342. See, e.g., L.C.H. v. T.S., 28 P.3d 915, 919 (Alaska 2001).

343. See, e.g., Louviere v. Louviere, 839 So. 2d 57 (La. Ct. App. 2002).

344. See, e.g., Mock v. Allen, 783 So. 2 d 828, 834 (Ala. 2000) (barring evidence of sexual assaults doctor committed on other men in light of tort reform statute).

345. See Doe v. Wal-Mart Stores, Inc., 558 S.E.2d 663, 674 (W. Va. 2001).

346. See Miller v. Brooks, 472 S.E.2d 350, 354 (N.C. Ct. App. 1996). The Florida Supreme Court rejected an intrusion on seclusion claim based on unwanted sexual touching in Allstate Ins. Co. v. Ginsberg, 863 So. 2d 156 (Fla. 2003).

347. DoBBs, supra note $151, \S 427$, at 1203 .

348. 16 P.3d 555, 553 (Utah 2000)

349. Id . at 557 .

350. Id.

351. Id. at 559 . 
sponse to the plaintiff's claim for invasion of privacy based on public disclosure of embarrassing facts, the court ruled that public disclosure had not occurred because the employer displayed the videotape of the assault to "only twelve to thirteen individuals," 352 some for the legitimate purposes of a criminal investigation, and others who were not specifically identified.

Another case in which privacy torts have not proven robust enough to protect victim privacy interests is Dye $v$. Wallace. ${ }^{353}$ In that case, the Georgia Supreme Court held that even publication of a child rape victim's name is not remediable in a tort privacy case based on the First Amendment rights enumerated in Florida Star v. B.F.J. ${ }^{354}$ However, in a footnote the court counseled that states can enact legislation requiring police to redact victims' identifying information. ${ }^{355}$ In some states, such legislation has been enacted and upheld. ${ }^{356}$

As in the criminal context, issues of privacy must be addressed in tort, to preserve victims' autonomy and dignity.

\section{CONCLUSION}

Like a mosaic of tiny pieces, the many recent judgments issued in cases filed by sexual assault victims present a picture of a contrasting and contested area of law without clear resolution. Ideally, state tort law meets its goals if it deters sexual assault, holds appropriate parties accountable for the damage done by the assaults, and provides adequate compensation to sexual assault victims. But how to deter sexual assault, who is responsible for it, and whether compensation should be more readily available and through which mechanisms are all open question-in the courts and in the culture more generally.

The idea that tort actions may be the solution to the problems in criminal law has some appeal. Rates of crime in schools and elsewhere have gone down precipitously in recent years, and it's an open question whether private policing (and the tort law that encourages it) deserves some of the credit. Moreover, movements toward victim compensation funds may do a better job of compensation, but do little to shape private incentives to reduce risk and may fit poorly with American tendencies to favor private-law remedies.

But caution about the fate of the public interest when victims drive the lawsuits is in order. ${ }^{357}$ Moreover, a culture can't simply step out of the room and leave itself behind. A change in fora brings a change in and not the disappearance of contested issues. Any number of issues arise from

352. Id.

353. 553 S.E.2d 561 (Ga. 2001).

354. Id. at 562 (citing Fla. Star v. B.F.J., 491 U.S. 524 (1989)).

355. Id. at 563 n.1.

356. See Cape Publ'ns v. City of Louisville, 147 S.W.3d 731, 735 (Ky. Ct. App. 2003).

357. See William H.J. Hubbard, Comment, Civil Settlement During Rape Prosecutions, 66 U. CHI. L. REv. 1231 (1999). 
the many cases resolved in the last few years alone. Courts and legislatures need to consider whether to create torts for touchings that are reckless or negligent with respect to harm or offense, create or avoid specially drawn statutes for victims of sexual assault, ${ }^{358}$ and increase access to legal services. Moreover, statutes specifically designed to protect crime victims in the civil courts may do more harm than good to victim interests if they import criminal-law rule into civil courts.

In terms of suits against third parties, though the defendant-duty issue is no longer the primary focus of third-party litigation, the questions of responsibility for rape prevention still are central-both on its own, and in relation to the responsibilities of others. How victims of these injuries can seek financial assistance and do so in a way that preserves their privacy and dignity becomes important as well. 359

The cases themselves do not answer the many policy questions that courts, the academic environment, and the broader public have set before them. However, the cases provide a vivid array of issues and analysis from which those policy discussions can begin.

358. This has been done in some states. See Michael Kiefer, Statute of Limitations Altered: 2 Awards Could Total $\$ 19$ Mil, Ariz. Republic, Jul. 10, 2004, at 3B. But these changes have been argued to limit victim interests. See also Savage v. Utah, 104 P.3d 1242 (Utah 2004) (rejecting argument that discovery statute means that claims can be brought only against natural persons rather than corporations).

359. Perhaps it is also fair to ask at this juncture whether the viability of the tort law in third-party actions has stunted the development of the criminal law. See Belluck, supra note 6 , at $A 31$ (quoting a law professor who said he did not think grand juries and prosecutors in other jurisdictions would file criminal negligence charges against other diocese who hide and continue to expose children to sexual abuse because, although "dioceses have done horrible things for which they should be held fully accountable in civil courts, none of the dioceses have committed any crimes"). 


\section{APPENDIX A: STATE SUPREME COURT DECISIONS IN TORT ACTIONS FILED BY SEXUAL ASSAULT VICTIMS - JANUARY 1, 2000 TO DECEMBER 31, 2004.}

\section{Alabama}

Kennedy v. W. Sizzlin Corp., 857 So. 2d 71 (Ala. 2003).

E. Ala. Behavioral Med., P.C. v. Chancey, 883 So. 2d 162 (Ala. 2003). Ex Parte S. Baldwin Reg'l Med. Ctr. v. E.P., 785 So. 2d 368 (Ala. 2001). Ex parte Blankenship v. Jackson, 806 So. 2d 1186 (Ala. 2001).

Christensen v. S. Normal Sch., 790 So. 2d 252 (Ala. 2001).

Mock v. Allen, 783 So. 2d 828 (Ala. 2000).

Alaska

Bryson v. Banner Health Sys., 89 P.3d 800 (Alaska 2004).

Kodiak Island Borough v. Roe, 63 P.3d 1009 (Alaska 2003).

L.C.H. v. T.S., 28 P.3d 915 (Alaska 2001).

M.C. v. N. Ins. Co., 1 P.3d 673 (Alaska 2000).

Kim v. Nat'l Indem. Co., 6 P.3d 264 (Alaska 2000).

C.P. ex rel. M.L. v. Allstate Ins. Co., 996 P.2d 1216 (Alaska 2000).

\section{Arkansas}

Saine v. Comcast Cablevision of Ark., 126 S.W.3d 339 (Ark. 2003).

Doe v. Baum, 72 S.W.3d 476 (Ark. 2002).

Regions Bank \& Trust Co. v. Stone County Skilled Nursing Facility, Inc., 49 S.W.3d 107 (Ark. 2001).

\section{California}

Saelzler v. Advanced Group 400, 23 P.3d 1143 (2001).

\section{Colorado}

Keller v. Koca, No. 0450304, 2004 WL 2030494 (Colo. Sept. 13, 2004) (en banc).

State Farm Mut. Auto Ins. Co. v. Kastner, 77 P.3d 1256 (Colo. 2003). Wesp v. Everson, 33 P.3d 191 (Colo. 2001).

Horodyskyj v. Karanian, 32 P.3d 470 (Colo. 2001) (en banc).

Slack v. Farmers Ins. Exch., 5 P.3d 280 (Colo. 2000).

\section{Conniecticuit}

Bd. of Educ. of the City of Bridgeport v. St. Paul Fire \& Marine Ins. Co., 801 A.2d 752 (Conn. 2002).

Vibert v. Bd. of Educ. of Reg'l Sch. Dist. No. 10, 793 A.2d 1076 (Conn. 2002).

Driscoll v. Gen. Nutrition Corp., 752 A.2d 1069 (Conn. 2000). 
Cmty. Action for Greater Middlesex County Inc. v. Am. Alliance Ins. Co., 757 A.2d 1074 (Conn. 2000).

\section{Florida}

Allstate Ins. Co. v. Ginsberg, 863 So. 2d 156 (Fla. 2003).

Doe v. Evans, 814 So. 2d 370 (Fla. 2002).

Malicki v. Doe, 814 So. 2d 347 (Fla. 2002).

Herzfeld v. Herzfeld, 781 So. 2d 1070 (Fla. 2001).

Hearndon v. Graham, 767 So. 2d 1179 (Fla. 2000).

Nova Southeastern Univ., Inc. v. Gross, 758 So. 2d 86 (Fla. 2000).

Georgia

Piedmont Hosp. Inc. v. Palladino, 580 S.E.2d 215 (Ga. 2003).

Munroe v. Universal Health Servs., 596 S.E.2d 604 (Ga. 2004).

Dye v. Wallace, 553 S.E.2d 561 (Ga. 2001).

\section{Hawaii}

Arquero v. Hilton Hawaiian Vill. LLC, 91 P.3d 505 (Haw. 2004).

Doe Parents No. 1 v. Dep't of Educ., 58 P.3d 545 (Haw. 2003).

\section{Idaho}

Hunter v. Dep't of Corr., 57 P.3d 755 (Idaho 2002).

\section{Illinois}

Doe ex. red. Ortega-Piron v. Chicago Board of Educ., 820 N.E.2d 418 (IIl. 2004).

Parks v. Kownacki, 737 N.E.2d 287 (Ill. 2000).

Clay v. Kuhl, 727 N.E.2d 217 (Ill. 2000).

\section{Indiana}

Robins v. Harris, 769 N.E.2d 586 (Ind. 2002).

\section{Iowa}

Horak v. Argosy Gaming Co., 648 N.W.2d 137 (Iowa 2002).

United Fire \& Cas. Co. v. Shelly Funeral Home, Inc., 642 N.W.2d 648 (Iowa 2002).

\section{Kentucky}

Pathways v. Hammons, 113 S.W.3d 85 (Ky. 2003).

\section{Louisiana}

Goins v. Wal-Mart Stores, Inc., 800 So. 2d 783 (La. 2001). 


\section{Maine}

Cyr v. Adamar Assocs. Ltd. P'ship., 752 A.2d 603 (Me. 2000).

Korhonen v. Allstate Ins. Co., 827 A.2d 833 (Me. 2003).

Napieralski v. Unity Church of Greater Portland, 802 A.2d 391 (Me. 2002).

Liberty v. Liberty, 769 A.2d 845 (Me. 2001).

Stanton v. Univ. of Me. Sys., 773 A.2d 1045 (Me. 2001).

\section{Maryland}

Montgomery County Bd. of Educ. v. Horace Mann Ins., 860 A.2d 909 (Md. 2004).

Wolfe v. Anne Arundel County, 821 A.2d 52 (Md. 2003).

\section{Massachusetts}

Ross v. Garabedian, 742 N.E.2d 1046 (Mass. 2001).

\section{Michigan}

Beaudrie v. Henderson, 631 N.W.2d 308 (Mich. 2001).

Bean v. Directions Unlimited, Inc., 609 N.W.2d 567 (Mich 2000).

Minnesota

K.R. v. Sanford, 605 N.W.2d 387 (Minn. 2000).

\section{Mississippi}

Univ. of S. Miss. v. Williams, 891 So. 2d 160 (Miss. 2004).

Simpson v. Boyd, 880 So. 2d 1047 (Miss. 2004).

Dupree v. Plantation Pointe, L.P., 892 So. 2d 228 (Miss. 2004).

Doe v. Stegall, 900 So. 2d 357 (Miss. 2004).

Doe v. State ex. rel. Miss. Dep't. of Corr., 859 So. 2d 350 (Miss. 2003).

Doe v. Salvation Army, 835 So. $2 d 76$ (Miss. 2003).

Glover v. Jackson State Univ., 755 So. 2d 395 (Miss. 2000).

\section{Missouri}

L.A.C. v. Ward Parkway Shopping Ctr. Co., 75 S.W.3d 247 (Mo. 2002).

\section{Montana}

Beaver v. Mont. Dep't of Natural Res. \& Conservation, 78 P.3d 857 (Mont. 2003).

\section{Nebraska}

Stahlecker v. Ford Motor Co., 667 N.W.2d 244 (Neb. 2003).

Bradley v. Cent. Catholic High Sch., 653 N.W.2d 813 (Neb. 2002).

R.W. v. Schrein, 652 N.W.2d 574 (Neb. 2002). 
R.W. v. Schrein, 642 N.W.2d 505 (Neb. 2002).

Brandon v. Richardson, 653 N.W.2d 829 (Neb. 2002).

Brandon v. County of Richardson, 624 N.W. 2d 604 (Neb. 2001).

New Hampshire

Murray v. Developmental Servs., 818 A.2d 302 (N.H. 2003).

Kravitz v. Beech Hill Hosp., 808 A.2d 34 (N.H. 2002).

Ross v. Home Ins. Co., 773 A.2d 654 (N.H. 2001).

New Jersey

Velez v. City of Jersey City, 850 A.2d 1238 (N.J. 2004).

New Mexico

Ocana v. Am. Furniture Co., 91 P.3d 58 (N.M. 2004).

New York

Catherine G. v. County of Essex, 818 N.E.2d 1110 (N.Y. 2004).

RJC Realty Holding Corp. v. Republic Franklin Ins. Co., 808 N.E.2d 1263 (N.Y. 2004).

Jeffreys v. Griffin, 801 N.E.2d 404 (N.Y. 2003).

Diaz v. N.Y. Downtown Hosp., 784 N.E.2d 68 (N.Y. 2002).

N.X. v. Cabrini Medical Ctr., 739 N.Y.S.2d 348 (N.Y. 2002).

Mason v. U.E.S.S. Leasing Corp., 730 N.Y.S.2d 770 (N.Y. 2001).

North Carolina

Wood v. Guilford County, 558 S.E.2d 490 (N.C. 2002).

\section{Ohio}

Yates v. Mansfield Bd. of Educ., 808 N.E.2d 861 (Ohio 2004).

Hubbard v. Canton City Sch. Bd. of Educ., 780 N.E.2d 543 (Ohio 2002).

\section{Oklahoma}

Rogers v. Burger King Corp., 82 P.3d 116 (Okla. 2003).

\section{Oregon}

Minnis v. Or. Mut. Ins. Co., 48 P.3d 137 (Or. 2002).

Rhode Island

Am. Commerce Ins. Co. v. Porto, 811 A.2d 1185 (R.I. 2002).

Ryan v. Roman Catholic Bishop of Providence, 787 A.2d 1191 (R.I. 2002).

Martin v. Howard, 784 A.2d 291 (R.I. 2001). 
Seddon v. Bonner, 755 A.2d 823 (R.I. 2000).

South Carolina

Frazier v. Badger, 603 S.E.2d 587 (S.C. 2004).

South Dakota

St. Paul Fire \& Marine Ins. Co. v. Engelmann, 639 N.W.2d 192 (S.D. 2002).

Martinmass v. Engelmann, 612 N.W.2d 600 (S.D. 2000).

Tennessee

Houghton v. Aramark Educ. Res., Inc., 90 S.W.3d 676 (Tenn. 2002).

\section{Texas}

Gomez v. Hous. Auth. of the City of El Paso, 148 S.W.3d 471 (Texas 2004).

Roman Catholic Diocese of Dallas v. Interstate Fire \& Cas. Co., 133 S.W.3d 887 (Texas 2004).

Buck v. Blum, 130 S.W.3d 285 (Texas 2004).

\section{Utah}

Savage v. Utah, 104 P.3d 1242 (Utah 2004).

Smith v. Four Corners Mental Health Ctr., Inc. 70 P.3d 904 (Utah 2003).

Shattuck-Owen v. Snowbird Corp., 16 P.3d 555 (Utah 2000).

\section{Vermont}

Doe v. Forrest, 853 A.2d 48 (Vt. 2004).

N. Sec. Ins. Co. v. Perron, 777 A.2d 151 (Vt. 2001).

In re Estate of Peters, 765 A.2d 468 (Vt. 2000).

\section{Virginia}

Billups v. Carter, 604 S.E.2d 414 (Va. 2004).

Niese v. City of Alexandria, 564 S.E.2d 127 (Va. 2002).

Grimes v. Suzukawa, 551 S.E.2d 644 (Va. 2001).

Delk v. Columbia Healthcare Corp., 523 S.E.2d 826 (Va. 2000).

Majorana v. Crown Cent. Petroleum Corp., 539 S.E.2d 426 (Va. 2000).

\section{Washington}

Clark v. Baines, 84 P.3d 245 (Wash. 2004).

Haley v. Highland, 12 P.3d 119 (Wash. 2000). 


\section{West Virginia}

W. Va. Fire \& Casualty Co. v. Stanley, 602 S.E.2d 483 (W. Va. 2004). Arbaugh v. Bd. of Educ., 214 W. Va. 677 (W. Va. 2003).

Miller v. Monongali County Bd. of Educ., 556 S.E.2d 427 (W. Va. 2001).

Doe v. Wal-Mart Stores, Inc., 558 S.E.2d 663 (W. Va. 2001).

Wisconsin

Gritzner v. Michael R., 611 N.W.2d 906 (Wis. 2000).

Wyoming

T.M. v. Executive Risk Indem. Inc., 59 P.3d 721 (Wyo. 2003).

McCulloh v. Drake, 24 P.3d 1162 (Wyo. 2001). 


\section{APPENDIX B: SOME RECENT STATE APPELLATE COURT DECISIONS IN TORT ACTIONS FILED BY SEXUAL ASSAULT VICTIMS.}

\section{Alabama}

M.L.E. v. K.B., 794 So. 2d 1143 (Ala. Ct. App. 2001).

E.P. v. McFadden, 785 So. 2d 364 (Ala. Ct. App. 2000).

\section{Arizona}

Watson v. Roman Catholic Church of the Diocese of Phoenix, Inc., 64 P.3d 195 (Ariz. Ct. App. 2002).

Rashedi v. General Bd. of Church of the Nazarene, 54 P.3d 349 (Ariz. Ct. App. 2002).

\section{Arkansas}

Regions Bank \& Trust, N.A. v. Stone County Skilled Nursing Facility, Inc., 30 S.W.3d 916 (Ark. Ct. App. 2001).

\section{California}

M.W. v. Panama Buena Vista Union Sch. Dist., 1 Cal. Rptr. 3d 673 (Cal. Ct. App. 2003).

County of Los Angeles Sheriff's Dep't v. Superior Court, 2002 WL 31525339 (Cal. App. 2002.)

Doe v. City of Murrieta, 126 Cal. Rptr. 2d 213 (Cal. Ct. App. 2002).

John Y., Jr. v. Chaparral Treatment Ctr., Inc., 124 Cal. Rptr. 2d 330 (Cal. Ct. App. 2002).

Hopkins v. San Diego Unified Port Dist., No. D03898W, 2002 WL 1824964 (Cal. Ct. App. Aug. 9, 2002).

Low v. Golden Eagle Ins. Co., No. A095218, 2002 WL 386415 (Cal. Ct. App. 2002).

Romero v. Superior Court, 107 Cal. Rptr. 2d 801 (Cal. App. 2001).

Maria D. v. Westec Residential Sec., Inc., 102 Cal. Rptr. 2d 326 (Cal. Ct. App. 2000).

\section{Colorado}

Koca v. Keller, 97 P.3d 346 (Colo. Ct. App. 2004).

State Farm Mut. Auto. Ins. Co. v. Kastner, 56 P.3d 1144 (Colo. Ct. App. 2002).

Sandoval v. Archdiocese of Denver, 8 P.3d 598 (Colo. Ct. App. 2000).

\section{Connecticut}

Doe v. Thames Valley Council for Cmty. Action, Inc., 797 A.2d 1146 (Conn. App. Ct. 2002). 


\section{District of Columbia}

Dist. of Columbia v. Harris, 770 A.2d 82 (D.C. 2001).

Brown v. Argenbright Sec. Inc., 782 A.2d 752 (D.C. 2001).

\section{Florida}

Griffin v. City of Opa Locka, 891 So. 2d 1127 (Fla. Dist. Ct. App. 2004). Borderline

Cedars Healthcare Group v. Freeman, 829 So. 2d 390 (Fla. Dist. Ct. App. 2002).

Boehnen v. Carnival Cruise Lines, Inc., 778 So. 2d 1084 (Fla. Dist. Ct. App. 2001).

M.S. v. Nova Southeastern Univ., Inc., 881 So. $2 \mathrm{~d} 614$ (Fla. Dist. Ct. App. 2001).

Iglesia Cristiana La Casa Del Senor, Inc. v. L.M., 783 So. 2 d 353 (Fla. Dist. Ct. App. 2001).

Tobin v. Damian, 772 So. 2d 13 (Fla. Dist. Ct. App. 2000).

Doe v. Malicki, 771 So. 2d 545 (Fla. Dist. Ct. App. 2000).

\section{Georgia}

Blier v. Greene, 587 S.E.2d 190 (Ga. Ct. App. 2004).

TGM Ashley Lakes, Inc. v. Jennings, No. A05A1401, 2003 WL 22846351 (Ga. Ct. App. Dec. 1, 2003).

Carter v. Glenn, 548 S.E.2d 110 (Ga. Ct. App. 2001).

Carter v. Glenn, 533 S.E.2d 109 (Ga. Ct. App. 2000).

\section{Hawaii}

Doe v. Grosvenor Ctr. Assocs., 92 P.3d 1010 (Haw. Ct. App. 2004).

Doe v. City \& County of Honolulu, 6 P.3d 362 (Haw. Ct. App. 2000).

\section{Illinois}

Doe v. Chicago Bd. of Educ., 791 N.E.2d 1283 (Ill. App. 2003).

SCR Medical Transportation Servs., Inc. v. Browne, 781 N.E.2d 564 (Ill. App. Ct. 2002).

Am. Family Mut. Ins. Co. v. Enright, 781 N.E.2d 394 (Ill. App. Ct. 2002).

Chelkova v. Southland Corp., 771 N.E.2d 1100 (Ill. App. Ct. 2002).

Sears, Roebuck \& Co. v. Nat'l Union, 772 N.E.2d 247 (Ill. App. Ct. 2002).

Friedman v. Safe Sec.rity Servs., Inc., 765 N.E.2d 104 (Ill. App. Ct. 2002).

\section{Indiana}

Southport Little League v. Vaughan, 734 N.E.2d 261 (Ind. Ct. App. 2000). 


\section{Iowa}

Stettnichs v. Lyon County, No. 00-2022, 2002 WL 571799 (Iowa Ct. App. 2002).

Riniker v. Wilson, 623 N.W.2d 220 (Iowa Ct. App. 2000).

Kansas

D.W. v. Bliss, 112 P.3d 232 (Kan. 2005).

\section{Kentucky}

Roman Catholic Bishop v. Burden, 168 S.W.3d 414 (Ky. Ct. App. 2004).

Koenigstein v. McKee, No. 2002-CA-002212-MR, 2004 WL 41738 (Ky. Ct. App. Jan. 9, 2004) (ordered not published, original on file with the author).

\section{Louisiana}

Sanborn v. Methodist Behavioral Res. P'ship, No. 2003-019-0627, 2004 WL 76850 (La. Ct. App. Jan. 14, 2004).

Ashmore v. Hilton, 834 So. 2d 1131 (La. Ct. App. 2003).

Louviere v. Louviere, 839 So. $2 d 57$ (La. Ct. App. 2002).

Vaughn v. Orleans Parish Sch. Bd., 802 So. 2d 967 (La. Ct. App. 2001).

Bonds v. Abbeville Gen. Hosp., 782 So. 2d 1188 (La. Ct. App. 2001).

Frederick v. Vermilion Parish Sch. Bd., 772 So. 2d 208 (La. Ct. App. 2001).

Bacas v. Falgoust, 760 So. 2d 1279 (La. Ct. App. 2000).

\section{Maryland}

Tate v. Bd. of Educ., 843 A.2d 890 (Md. Ct. App. 2004).

Moore v. Jimel, Inc., 809 A.2d 10 (Md. Ct. App. 2002).

Fried v. Archer, 775 A.2d 430 (Md. Ct. App. 2001).

\section{Massachusetts}

Or v. Edwards, 818 N.E.2d 163 (Mass. App. Ct. 2004).

United Servs. Auto. Ass'n v. Doe, 792 N.E.2d 708 (Mass. App. Ct. 2003).

Westerback v. Harold F. LeClair Co., 735 N.E.2d 1256 (Mass. App. Ct. 2000).

\section{Maryland}

Wolfe v. Anne Arundel County, 761 A.2d 935 (Md. Ct. Spec. App. 2000). 


\section{Michigan}

Doe v. Roman Catholic Archbishop, 692 N.W.2d 398 (Mich. Ct. App. 2004).

Salinas v. Genesys Health Sys., 688 N.W.2d 112 (Mich. Ct. App. 2004).

Miller v. Lord, 686 N.W.2d 800 (Mich. Ct. App. 2004).

Allstate Ins. Co. v. J.J.M., 657 N.W.2d 181 (Mich. Ct. App. 2002).

\section{Minnesota}

Doe v. St. Philips Parish, 2002 WL 1461740 (Minn. Ct. App. 2002).

\section{Mississippi}

Dupree v. Plantation Pointe, L.P., 881 S.2d 832 (Miss. Ct. App. 2003).

T.K. v. Simpson County School Dist., 846 So. 2d 312 (Miss. Ct. App. 2003).

Doe v. N. Panola Sch. Dist., 906 So. 2 d 57 (Miss. Ct. App. 2001).

\section{Missouri}

Richardson v. Quiktrip Corp., 81 S.W.3d 54 (Mo. Ct. App. 2002).

L.A.C. v. Ward Parkway Shopping Ctr. Co., L.P., 2001 WL 376347 (Mo. Ct. App. 2001).

Weaver v. African Methodist Episcopal Church, Inc., 54 S.W.3d 575 (Mo. Ct. App. 2001).

Reed v. Kelly, 37 S.W.3d 274 (Mo. Ct. App. 2001).

H.R.B. v. Rigali, 18 S.W.3d 440 (Mo. Ct. App. 2000).

\section{New Jersey}

Martin v. Prime Hospitality Corp., 785 A.2d 16 (N.J. Sup. Ct. 2001).

New York

Ace Fire Underwriters Ins. Co. v. Orange-Ulster Bd. of Coop. Educ. Servs., 768 N.Y.S.2d 486 (N.Y. App. Div. 2003).

Gomes v. City of New York, 758 N.Y.S.2d 298 (N.Y. App. Div. 2003).

Dia CC v. Ithaca City Sch. Dist., 758 N.Y.S.2d 197 (N.Y. App. Div. 2003).

Weldon v. Rivera, 754 N.Y.S.2d 698 (N.Y. App. Div. 2003).

Doe v. Westfall Health Care Ctr., Inc., 755 N.Y.S.2d 769 (N.Y. App. Div. 2002).

Wienclawski v. N.Y. Sch. for the Deaf, 753 N.Y.S.2d 95 (N.Y. App. Div. 2002).

Brian VV v. Chenango Forks Cent. School Dist., 751 N.Y.S.2d 59 (N.Y. App. Div. 2002).

Michael G. and Kenneth G. v. Athletic Alliance Risk Purchasing Group, 747 N.Y.S.2d 884 (N.Y. App. Div. 2002).

J.E. v. Beth Israel Hosp., 744 N.Y.S.2d 166 (N.Y. App. Div. 2002). 
Rice v. St. Luke's-Roosevelt Hosp. Ctr., 739 N.Y.S.2d 384 (N.Y. App. Div. 2002).

Physicians' Reciprocal Insurers v. Loeb, 738 N.Y.S.2d 68 (N.Y. App. Div. 2002).

Camp v. Loughran, 727 N.Y.S.2d 471 (N.Y. App. Div. 2001).

Mary Anne "ZZ" v. Blasen, 726 N.Y.S.2d 767 (N.Y. App. Div. 2001).

Vitale v. Rosina Food Prod. Inc., 727 N.Y.S.2d 215 (N.Y. App. Div. 2001).

Lara v. City of New York, 726 N.Y.S.2d 217 (N.Y. App. Div. 2001).

Serpa v. County of Nassau, 720 N.Y.S.2d 546 (N.Y. App. Div. 2001).

N.X. v. Cabrini Medical Ctr., 719 N.Y.S.2d 60 (N.Y. App. Div. 2001).

San Juan v. Leach, 717 N.Y.S.2d 334 (N.Y. App. Div. 2000).

Christopher S. v. Douglaston Club, 713 N.Y.S.2d 542 (N.Y. App. Div. 2000).

Randall v. Tod-Nik Audiology, Inc., 704 N.Y.S.2d 228 (N.Y. App. Div. 2000).

\section{North Carolina}

Young v. Great American Ins. Co. of New York, 590 S.E.2d 4 (N.C. Ct. App. 2004).

Allstate Ins. Co. v. Lahoud, 167 N.C. App. 205 (N.C. Ct. App. 2004). Wood v. Guilford County, 143 N.C. App. 507 (N.C. Ct. App. 2001). Doe v. Jenkins, 547 S.E.2d 124 (N.C. Ct. App. 2001).

\section{Ohio}

A.S. v. Fairfield Sch. Dist., No. CA2003-04, 2003 WL 22764383 (Ohio Ct. App. Nov. 24, 2003).

Waters v. Allied Machine \& Eng'g Corp., No. 02A0940032, 2003 WL 21027180 (Ohio Ct. App. Apr. 30, 2003).

Collins v. Carpenter, No. 02CA31, 2002 WL 31161099 (Ohio Ct. App. Sept. 30, 2002).

Shivers v. Univ. of Cincinnati, No. 2000-02461, 2002 WL 31991924 (Ohio Ct. Cl. Mar. 4, 2002).

Doe v. Beach House Dev. Co., 737 N.E.2d 141 (Ohio Ct. App. 2000).

Rembert v. Dep't of Rehabilitation \& Corr., No. 2003-03582, 2003 WL 22407377 (Ohio Ct. Cl. Oct. 2, 2003).

\section{Oklahoma}

Rogers v. Burger King Corp., 82 P.3d 116 (Okla. Civ. App. 2003).

\section{Pennsylvania}

R.W. v. Manzek, 838 A.2d 801 (Pa. Super. Ct. 2003).

Krasevic v. Goodwill Indus. of Cent. Pa., Inc., 764 A.2d 561 (Pa. Super. Ct. 2001). 


\section{South Carolina}

Padgett v. S.C. Ins. Reserve Fund, 531 S.E.2d 305 (S.C. Ct. App. 2000).

\section{Tennessee}

Doe v. May, No. E2003-1642-COA-K3-CV, 2004 WL 1459402 (Tenn. Ct. App. Dec. 28, 2004).

J.W. v. Maury County, No. M2001-02768-COA-R3-CV, 2003 WL 1018138 (Tenn. Ct. App. Sept. 2, 2003).

Doe v. Mama Taori's Premium Pizza, L.L.C., No. M1998-00992-COAleg-CV, 2001 WL 327906 (Tenn. Ct. App. Apr. 5, 2001).

\section{Texas}

Olivarez v. Doe, 164 S.W.3d 427 (Tex. App.-Tyler 2004, pet. denied). Lively v. Adventist Health Sys./Sunbelt, Inc., No. 2-02-418-CV, 2004 WL 1699913 (Tex. App.-Fort Worth 2004, no pet.).

Fielder Rd. Baptist Church v. GuideOne Elite Ins., Co., 139 S.W.3d 384 (Tex. App.-Fort Worth 2004, pet. granted).

Jones v. Khorsandi, 148 S.W.3d 201 (Tex. App.-Eastland 2004, pet. denied).

Brown v. Houston Indep. Sch. Dist., No. 14-02-00967-CV, 2003 WL 22707322 (Tex. App.-Houston [14th Dist.] 2003, pet. denied).

Urena v. W. Invs., Inc., 122 S.W.3d 249 (Tex. App.-Houston [14th Dist.] 2003, pet. granted).

Palacios v. Robbins, No. 04-02-00358-CV, 2003 WL 21502371 (Tex. App.-San Antonio July 2, 2003, pet. denied).

J.T.T. v. Chon Tri, 111 S.W.3d 680 (Tex. App.-Houston [1st Dist.] 2003).

Smith v. Holmes, 2003 WL 1561321 (Tex. App. -Austin 2003, no pet.).

Bonham v. Tex. Dep't of Criminal Justice, 101 S.W.3d 153 (Tex. App. 2003).

Crain v. Prasifka, 97 S.W.3d 867 (Tex. App.-Corpus Christi 2003, pet. denied).

Healthcare Ctrs. of Tex., Inc. v. Rigby, 97 S.W.3d 610 (Tex. App.Houston [14th Dist.] 2003, pet. denied).

Capece v. Navisite, Inc., No. 03-02-00113-CV, 2002 WL 31769032 (Tex. App.-Austin 2002, no pet.).

Zuniga v. Healthcare San Antonio, Inc., 94 S.W.3d 778 (Tex. App.San Antonio 2002, no pet.).

Acceptance Ins. Co. v. Lifecare Corp., 89 S.W.3d 773 (Tex. App.Corpus Christi 2002, no pet.).

May v. Nacogdoches Mem'l Hosp., 61 S.W.3d 623 (Tex. App.-Tyler 2001, no pet.).

Tarrant County Hosp. Dist. v. Henry, 52 S.W.3d 434 (Tex. App.-Tyler 2001, no pet.). 
Myers v. Doe, 52 S.W.3d 391 (Tex. App.-Fort Worth 2001, pet. denied).

In re Doe, 22 S.W.3d 601 (Tex. App-Austin. 2000, pet. granted).

\section{Utah}

Colosimo v. Roman Catholic Bishop of Salt Lake City, 104 P.3d 646 (Utah Ct. App. 2004).

Atkinson v. Stateline Hotel Casino \& Resort, 21 P.3d 667 (Utah Ct. App. 2001).

\section{Washington}

Faulkner v. Racquetwood Vill. Condo. Ass'n, 23 P.3d 1135 (Wash. Ct. App. 2001).

\section{Wisconsin}

Peterson v. Arlington Hospitality Staffing, Inc., 689 N.W.2d 61 (Wis. Ct. App. 2004).

Schauer v. Diocese of Green Bay, 687 N.W.2d 766 (Wis. Ct. App. 2004).

Christman v. Galanton, No. 03-02405, 2004 WL 1533991 (Wis. Ct. App. June 30, 2004).

B.N. v. Giese, 685 N.W.2d 568 (Wis. Ct. App. 2004).

Thomas G v. Michael R., 668 N.W.2d 562 (Wis. Ct. App. 2003).

St. Paul Fire \& Marine Ins. Co. v. Keltgen, 659 N.W.2d 906 (Wis. Ct. App. 2003).

Stauss v. Oconomowoc Residential Programs, Inc., 621 N.W.2d 917 (Wis. Ct. App. 2000). 